\title{
Influence of mycorrhizal fungi on soil geochemistry and plant uptake of cadmium and zinc: greenhouse and soil studies of Palmerton Zinc Superfund Site, Pennsylvania, u.s.a
}

\author{
Christian X. Figueroa
}

Follow this and additional works at: https://researchrepository.wvu.edu/etd

\section{Recommended Citation}

Figueroa, Christian X., "Influence of mycorrhizal fungi on soil geochemistry and plant uptake of cadmium and zinc: greenhouse and soil studies of Palmerton Zinc Superfund Site, Pennsylvania, u.s.a" (2015). Graduate Theses, Dissertations, and Problem Reports. 5596.

https://researchrepository.wvu.edu/etd/5596

This Thesis is protected by copyright and/or related rights. It has been brought to you by the The Research Repository @ WVU with permission from the rights-holder(s). You are free to use this Thesis in any way that is permitted by the copyright and related rights legislation that applies to your use. For other uses you must obtain permission from the rights-holder(s) directly, unless additional rights are indicated by a Creative Commons license in the record and/ or on the work itself. This Thesis has been accepted for inclusion in WVU Graduate Theses, Dissertations, and Problem Reports collection by an authorized administrator of The Research Repository @ WVU. For more information, please contact researchrepository@mail.wvu.edu. 
Influence of mycorrhizal fungi on soil geochemistry and plant uptake of cadmium and zinc: greenhouse and soil studies of Palmerton Zinc Superfund Site, Pennsylvania, U.S.A.

\title{
Christian X. Figueroa
}

\author{
Thesis submitted to the \\ Eberly College of Arts and Sciences \\ at West Virginia University \\ in partial fulfillment of the requirements \\ for the degree of \\ Master of Science \\ in \\ Geology \\ Dr. Dorothy J. Vesper, Ph.D, Chair \\ Dr. Jonathan Cumming, Ph.D. \\ Dr. Helen Lang, Ph.D. \\ Department of Geology and Geography
}

\section{Morgantown, West Virginia \\ 2015}

Keywords: cadmium, Populus, Paxillus involutus, phytoremediation, sequential extraction, singleextraction methods, zinc

Copyright 2015 Christian Figueroa 


\begin{abstract}
Influence of mycorrhizal fungi on soil geochemistry and plant uptake of cadmium and zinc: greenhouse and soil studies of Palmerton Zinc Superfund Site, Pennsylvania, U.S.A.
\end{abstract}

\title{
Christian X. Figueroa
}

The application of bioremediation as a means to ameliorate potentially toxic metals from contaminated soils has been on the forefront of sustainable technologies in the field of environmental studies. Conventional methods available for soil remediation are employed in both in situ or ex situ and these are: soil flushing, solidification/stabilization, vitrification, electrokinetics, chemical reduction/oxidation, soil washing, and excavation. In general, these technologies are limited by their applicability to small areas and the high costs to execute. The use of biota, in particular fungi and trees, has been an emerging low-cost and "environmentallyfriendly" alternative to conventional technologies. In this study, I evaluate four soils collected from the Lehigh Gap Wildlife Refuge and Nature Center adjacent to the Palmerton Zinc Superfund Site by using commonly used single extraction methods and the revised European Bureau of Common References (BCR) sequential extraction to determine availability of Cd and Zn. I also explore how the rhizosphere-based method (RBM) that mimics rhizosphere conditions compares to the liquid cultures of the ectomycorrhizal fungus Paxillus involutus to interpret change in metal availability and the potential for environmental risk associated with fungal inoculation of soils when used to aid remediation projects. Additionally, comparison between extractants (EDTA, DTPA, Mehlich-III, Fraction 1 and Pseudototal of the revised BCR sequential extraction method) that evaluate plant availability to determine the efficacy of the previous mentioned extractants. Findings were that both components of the BCR method grossly overestimates both $\mathrm{Cd}$ and $\mathrm{Zn}$ compared to aforementioned extractants. Additionally, fungal liquid performed similarly to the Mehlich-III as comparable extractant for determining $\mathrm{Cd}$ and Zn availability, where fungal liquid and RBM had similar extractability for Zn only.

Work was also done to investigate effects of $P$. involutus and a Populus hybrid on fractionation of metals in these soils by the revised BCR sequential extraction method. Findings suggest that availability and mobility of $\mathrm{Cd}$ and $\mathrm{Zn}$ in contaminated soils can be altered significantly by P. involutus and Populus and plant uptake of $\mathrm{Cd}$ is greater than $\mathrm{Zn}$. With further 
research with more varieties of hybrid poplars and mycorrhizal fungi more effective symbionts can be chosen to aid in remediating metal contaminated sites that may pose a risk to the environment and human health. 


\section{Acknowledgements}

"Life is a journey, not a destination." These words from the late Ralph Waldo Emerson have been the mantra of both my education and personal life. Through this, the journey of life has led me through my experiences and has nourished my relationships and friendships. This being said, I am deeply indebted to both my main advisers Dr. Dorothy Vesper and Dr. Jonathan Cumming in allowing me to be a part of a larger collective experiment, education. They have both put forth valiant efforts to make sure that I complete my tasks, so I may move on with my journey into this world.

A huge shout out goes to all of my lab mates that have seen me come in and out of the lab whether I was in for the night of tedious soil extractions or on my way out to go catch the next pulse that feeds West Virginia's amazing rivers. My lab mates included but were not limited to: Dr. Dhiraj Naik, Ernest Smith and Shalaka Desai. All of these wonderful individuals provided me with insight and encouragement in a discipline that was originally foreign, helped shed light in furthering my understanding of plants and fungi.

Family has been my inspiration through this entire experience, providing me encouragement and support the entire way. My mother and father, Patty and Mark, have been incredible assets in fostering values and the fire that drives my curiosity. My youngest sister, Lauren, has always been a huge part of my life both intellectually and as an encouragement to push the envelope beyond my own comfort. My extended family, Uncles, Aunts, and Grandparents have always been there along the way and have shared their excitement for another

member of the family furthering themselves beyond the scope of my immigrant Grandparent's wildest dreams. 


\section{Table of Contents}

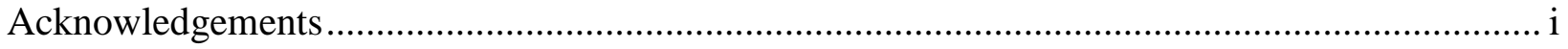

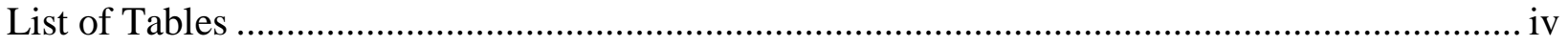

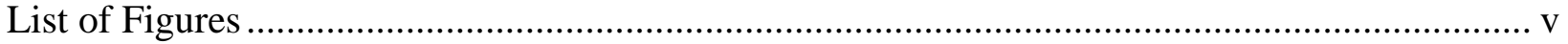

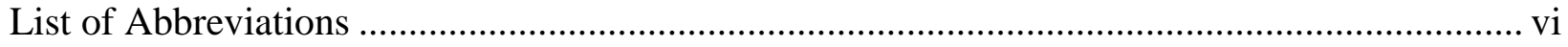

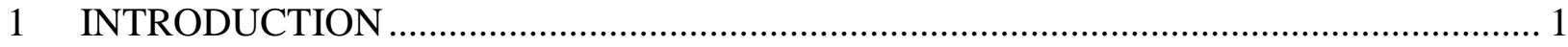

1.1 Plant-mycorrhizal interactions with toxic metals ............................................................ 1

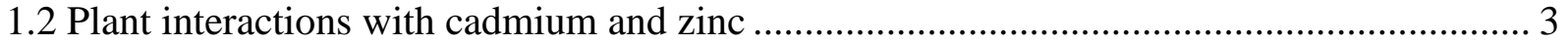

1.3 Interactions of cadmium and zinc in soils and the environment......................................... 5

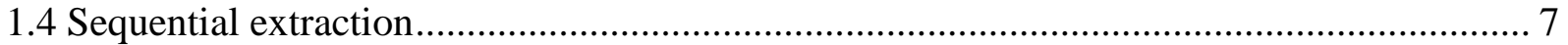

1.5 Single extraction methods to determine bioavailability.................................................. 9

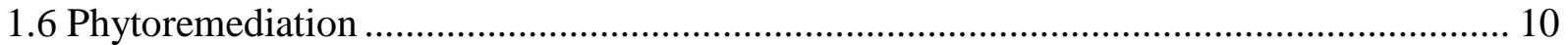

1.7 Lehigh Gap Wildlife Refuge and Nature Center and Palmerton Zinc Superfund Site ....... 12

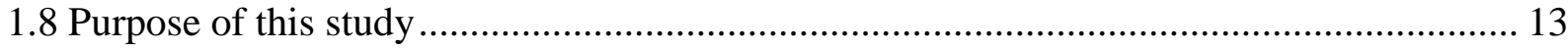

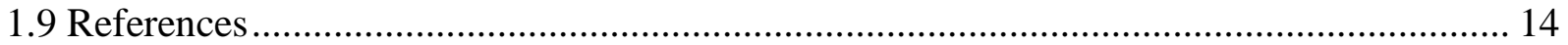

2 Cadmium and zinc partitioning in zinc smelter contaminated soils ....................................... 25

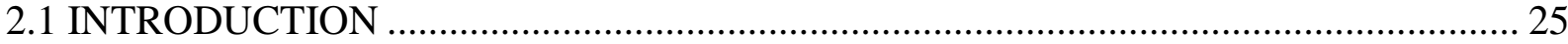

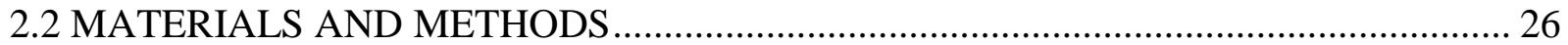

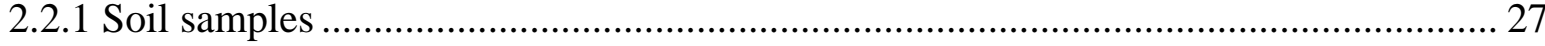

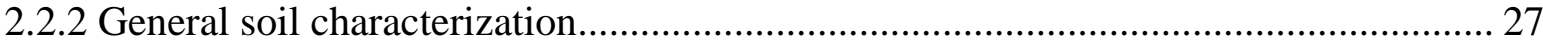

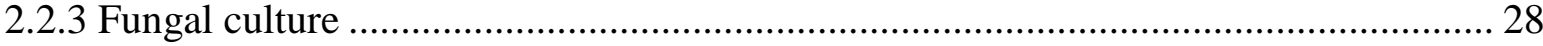

2.2.4 Determination of total metal concentrations in soil ................................................... 28

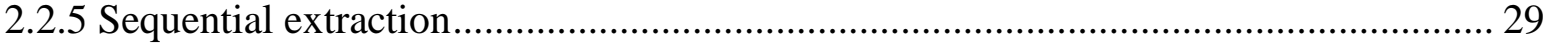

2.2.6 Single Extraction experiments ………………....................................................... 30

2.2.7 Analyses and quality control............................................................................... 31

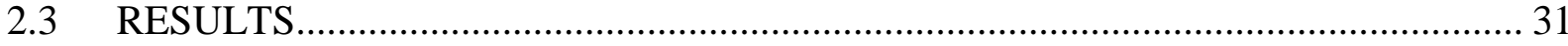

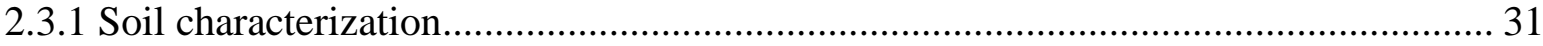

2.3.2 Sequential extraction........................................................................................... 31

2.3.3 Batch leaching extractions ..................................................................................... 33

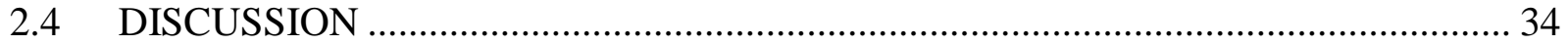

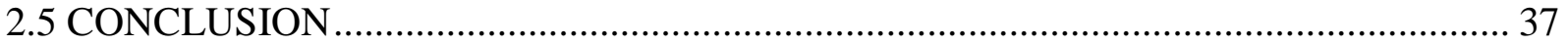

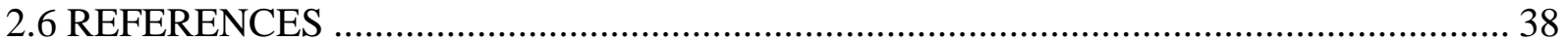

3 Effect of Paxillus involutus on fractionation and uptake by Populus hybrid of zinc and

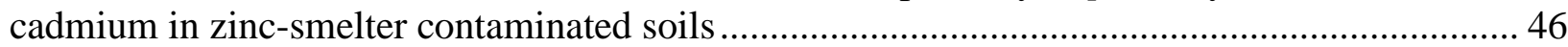




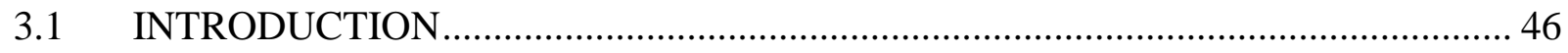

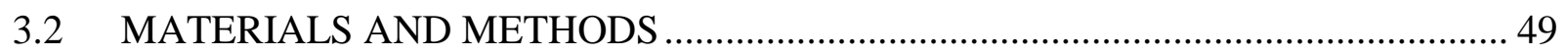

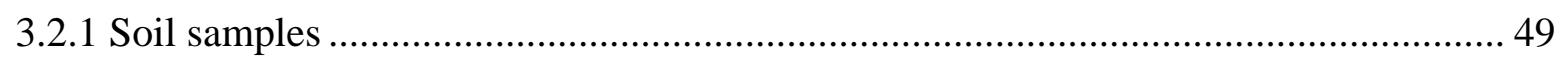

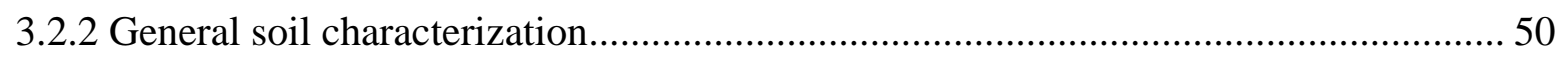

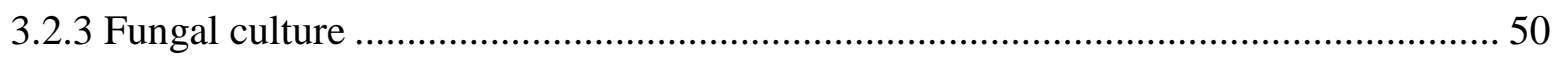

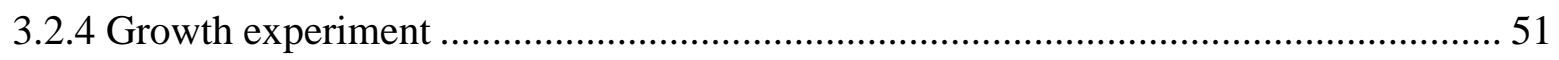

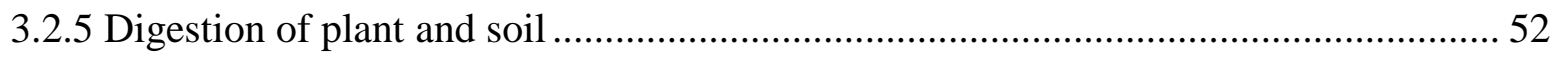

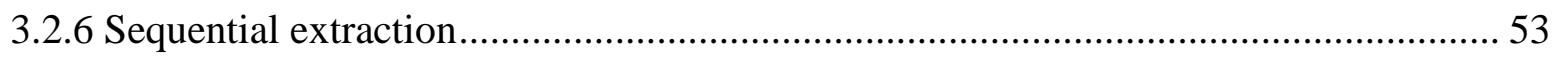

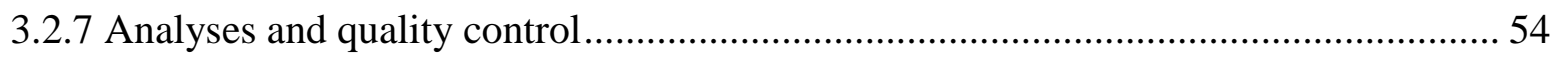

3.3 RESULTS

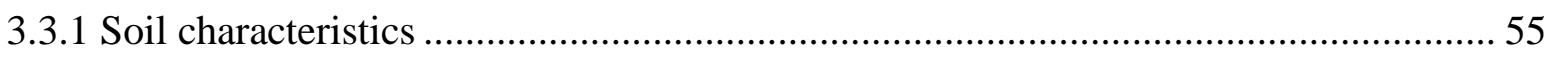

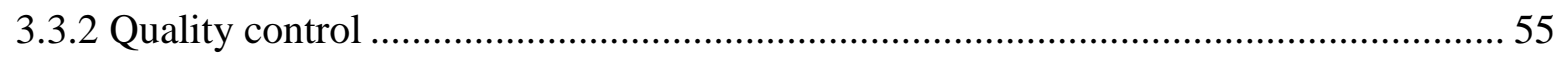

3.3.3 Tree growth and plant metal concentrations ............................................................. 56

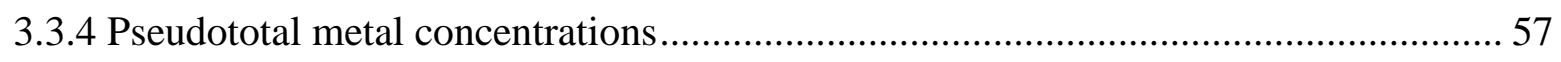

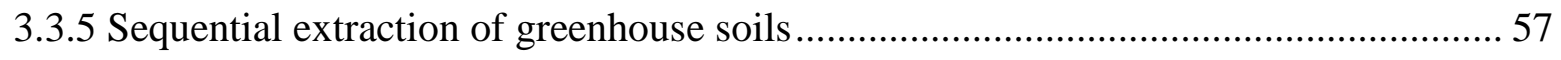

3.3.6 Mobility of metals in soils ..................................................................................... 59

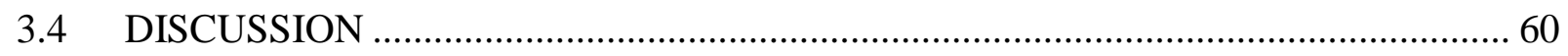

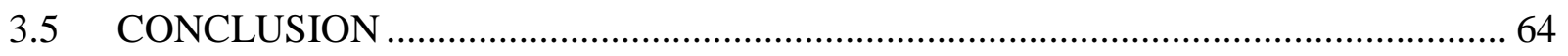

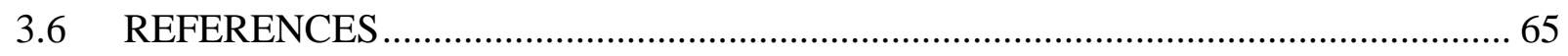

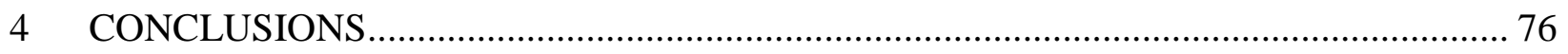

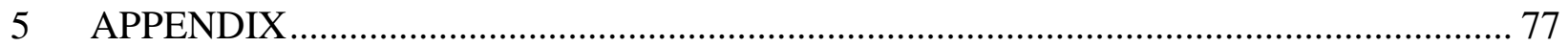




\section{List of Tables}

Table 1.1 Sequential Extraction Protocol

Table 2.1 Plot descriptions of site and sample locations at LGWR, Palmerton, Pennsylvania, U.S.A.

Table 2.2 Summary of Single Extractions used in Batch Leaching ........................................ 41

Table 2.3 Soil Characteristics of the LGWR, Palmerton, Pennsylvania, U.S.A ....................... 42

Table 2.4 Revised BCR Sequential Extraction Results for Palmerton Soils ............................. 43

Table 3.1 Soil Characteristics and Metal Availability for four soils collected from LGWR in Palmerton, Pennsylvania

Table 3.2 Summary statistics for Populus hybrid growth response to $\mathrm{Cd}$, Zn-contaminated soils and modification by inoculation with $P$. involutus....

Table 3.3 Pseudototal (aqua-regia soluble) of Cadmium and Zinc in LGWR soils following 8week growth with Populus and/or P. involutus (mg/kg)

Table A.1 Significance of treatment effects for soils exposed to mycorrhizal, poplar, and mycorrhizal x poplar treatments on non-amended and amended Palmerton (LGWR) soils in 8-week growth study.

Table A.2 Significance of treatment effects on Populus hybrid exposed to amended soils and mycorrhizal fungi ( $P$. involutus) in 8-week growth study. 


\section{List of Figures}

Figure 1.1 Satelite Imagery illustrating Palmerton Borough Vicinity and LGWR 20

Figure 1.2 USGS 1:100,000 Allentown Topographic Map illustrating Palmerton Borough and LGWR

Figure 1.3 Satellite Image Illustrating Sampling Locations at LGWR.................................... 22

Figure 1.4 USDA NRCS Soils Map with Sampling Locations at LGWR .............................. 23

Figure 1.5 Photography of Sampling Locations at LGWR ................................................. 24

Figure 2.1 Revised BCR Sequential Extraction results from LGWR, Palmerton, PA soils........ 44

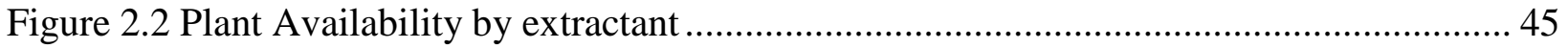

Figure 3.1 Revised BCR Sequential Extraction Fractionation Data for LGWR soils following 8weeks of growth with Populus and/or P. involutus.................................................. 72

Figure 3.2 Non-amended sample data from the Revised BCR Sequential Extraction Data LGWR soils following 8-weeks of growth with Populus and/or P. involutus. ...................... 73

Figure 3.3 Amended sample data from the Revised BCR Sequential Extraction Data LGWR soils following 8-weeks of growth with Populus and/or P. involutus.............................. 74

Figure 3.4 Leachate Depletion Curves for greenhouse experiment for LGWR soils following 8weeks of growth with Populus and/or P. involutus.... 


\section{List of Abbreviations}

$\mathrm{Al}=$ Aluminum

$\mathrm{AM}=$ Arbuscular Mycorrhiza(e)

ATPase $=$ Adenosine triphosphatase

$\mathrm{BCR}=$ Bureau of Common References

$\mathrm{CaCl}_{2}=$ Calcium chloride

$\mathrm{CaCO}_{3}=$ Calcium carbonate

$\mathrm{Cd}=$ Cadmium

$\mathrm{Cu}=$ Copper

Cys $=$ Cysteine

DTPA = Diethylenetetraaminepentaacetic Acid

DW $=$ Dry Weight

EDTA = Ethylenediaminetetraacetic Acid

$\mathrm{Fe}=$ Iron

Glu = Glutathione

Gly = Glycine

$\mathrm{H}^{+}=$Hydrogen ion

$\mathrm{K}^{+}=$Potassium ion

LGWR - Lehigh Gap Wildlife Refuge and Nature Center

LMWOA - Low molecular weight organic acids

$\mathrm{M}(\mathrm{mol} / \mathrm{L})=$ Molarity

$\mu \mathrm{g}=$ microgram

$\mathrm{mg} / \mathrm{kg}=$ milligram per kilogram

$\mathrm{mM}=$ millimolar

MMN - Modified Melin-Norkrans media

Mn = Manganese

Myc $=$ Mycorrhizae

NTA $=$ Nitrilotriacetic Acid

$\mathrm{Pb}=$ Lead

Pi/Pax $=$ Paxillus involutus

Pop $=$ Poplar $/$ Populus

PSII = Photosystem II

RBM = Rhizosphere Based Method

ROD - Record of Decision

$\mathrm{SD}=$ Standard Deviation

$\mathrm{SE}=$ Standard Error

USEPA - United States Environmental Protection Agency

USFWS - United States Fish and Wildlife Service

UNEP - United Nations Environment Programme

$\mathrm{Zn}=$ Zinc 


\section{INTRODUCTION}

Metals are ubiquitous within the environment, however due to anthropogenic activity, potentially toxic metals have become more commonplace and may affect biota and the environments in which they persist. Due to the bioavailability and potential for harm, metals have become a pollutant of concern where contaminated soils are prevalent. As a result of human activities such as mining and smelting of metalliferous ores, electroplating, fossil fuel exhaust, energy and fuel production, fertilizer and pesticide application, etc., metal pollution has become one of the most serious environmental problems today (Adriano, 2001; Alkorta et al., 2004). Metals exhibit a multiplicity of molecular-scale interactions with soil particulates or organic matter whereby they can be sequestered in the soil environment (Brown et al., 1999). Within an ecosystem, plants, soil microbes and fungi can transform metal solubility and availability extracellularly or may internally sequester metals and reduce their environmental burden (Kabata-Pendias, 2004; Bellion et al., 2006). Understanding these interactions between plants and soil microbes in contaminated soils may increase the capacity and appreciation for phytoremediation.

\subsection{Plant-mycorrhizal interactions with toxic metals}

Within the rhizosphere, most plants form symbiotic relationships with mycorrhizal fungi that enable availability of necessary nutrients as well increasing tolerances to environmental hazards. Mycorrhizal fungi have shown excellent efficacy in reducing metal toxicity to their host plants (Hartley et al., 1997; Godbold et al., 1998; Schützendübel and Polle, 2001) and these symbioses also assist in ameliorating toxicity of metals by transforming and sequestering these metals within the rhizosphere and intracellularly (Gadd, 2001; Hall, 2001; Meharg, 2003; Bellion

et al., 2006). The performance of mycorrhizal fungi in ameliorating the effect of metals is dependent on species and isolate, metal used or encountered, and experimental conditions. Fungal isolates from heavy metal contaminated sites have shown better success at tolerance than those fungi isolated from non-contaminated sites (Galli et al., 1994). Mechanisms that enable fungi to sequester metals within the extracellular environment include chelation by extruded 
organic compounds and binding to the cell-wall components (Gadd, 2001). Intracellularly, metals within the cytosol can be rendered inert by binding with a range of cytosolic ligands, increased efflux of heavy metal bound ligands out of the cytosol into the rhizosphere, and compartmentalization within sequestering organelles (Hartley et al., 1997).

Fungi have the capacity to limit intercellular passage by a variety of pathways. Exudation of different ligands under metal stress contributes to the overall reduction of influx of toxic metals into the cytosol. These ligands include low/high-molecular weight organic acids, siderophores, alcohols, proteins, polysaccharides, and other polymeric substances. Blaudez et al. (2000) observed that, in Paxillus involutus under cadmium stress, oxalic acid exudation reduced Cd uptake by $85 \%$, compared to six other organic acids, suggesting oxalate exudation under $\mathrm{Cd}$ stress may relieve entry into the cell, decreasing Cd availability. Formina et al. (2006) found that pine seedlings infected with a $\mathrm{Zn}$-resistant $P$. involutus strain accumulated less $\mathrm{Zn}$ in presence of $\mathrm{Zn}$-phosphate sources and increased dissolution and uptake in low-phosphorus conditions. Increased solubilization of phosphates is stimulated by organic acid exudation in response to phosphate deficiency and other nutrient stress and deficiencies (Jones, 1998), where these compounds may chelate or precipitate metals within the rhizosphere.

Extracellularly, metals can actively adhere to negatively charged sites that comprise the cell wall, such as chitin, cellulose, cellulose derivatives, polysaccharides, and melanin (Gadd, 1993; Blaudez et al., 2000). Frey et al. (2000) found that, in symbionts Picea abies-Hebeloma crustuliniforme, $\mathrm{Cd}$ was localized in the cell walls of the Hartig net, whereas $\mathrm{Zn}$ was localized within the cell wall of the mantle hyphae, Hartig net hyphae, and in the cell walls of the cortical cells. This eluded that $\mathrm{Cd}$ was being confined within the apoplast of the Hartig net, where $\mathrm{Zn}$ was being extracellularly complexed and or sequestered within the cytosol. Jentschke and Godbold (2000) noted that the mechanisms of amelioration by fungi of metal uptake from the rhizosphere is an extremely dynamic and not well understood process, in that more sorption related studies and exploration of the hydrophobic tendencies of mycorrhiza need to be carried out to understand the complexity of extracellular binding. 
Once metals have passed from the external environment into the cell there are several pathways in which metals can be translocated, sequestered, or discharged from the intracellular compartment to the exterior by efflux mechanisms or leakage. These mechanisms are enhanced by intracellular compartmentalization within organelles by complexation with sulfhydryl groups of metallothioneins and its derivatives (glutathione, $\gamma$-glutamylcysteine), which render these once toxic metals inert or by binding to polyphosphate granules (Galli et al., 1994; Meharg, 2003; Bellion et al., 2006). Metal-binding compounds include glutathione, metallothioneins, and phytochelatins and are produced in fungi during exposure to metals, whether in high or low concentrations (Courbot et al., 2004; Jaeckel et al., 2005). These compounds have a role in both transport and storage of metals and may help in combating against oxidative stress (Hartley et al., 1997; Noctor et al., 1998). Metallothioneins are cysteine-rich low molecular weight proteins that are virtually found in every organism on earth to help combat against metal toxicity. Phytochelatins scavenge metals ions by thiolate coordination, where phytochelatins have the general structure of $[\gamma-\text { GluCys }]_{n}$-gly $(n=2$ to 11$)$ that are enzymatically synthesized from glutathione, glycine, and cysteine amino acid residues. Polyphosphate granules located within vacuoles have also been found to be important in maintaining ionic compartmentation (Gadd, 1993; Galli et al., 1994) and that they have the capacity to bind most divalent metal cations, representing yet another means of intracellular metal detoxification.

\subsection{Plant interactions with cadmium and zinc}

Interactions between plant cells and potentially toxic elements are well documented in the literature (Marschner, 2002; Prasad, 2004). Both Zn and Cd show synergistic properties within plants due to their chemical behavior and likeness (Das et al., 1998). Where $\mathrm{Zn}$ is an essential element at appropriate concentrations, $\mathrm{Cd}$ is recognized to be lethal at extremely low concentrations. Due to the similarities between these ions, $\mathrm{Cd}$ is able to mimic the uptake properties of $\mathrm{Zn}$ and $\mathrm{Zn}$ may inhibit the uptake of $\mathrm{Cd}$ when at higher concentrations. When $\mathrm{Zn}$ is at low concentrations, plants will uptake more $\mathrm{Cd}$ than $\mathrm{Zn}$ (Kirkham, 2006). In soils the availability of both elements is strongly dependent on $\mathrm{pH}$; both elements form inorganic and organic complexes, which widely affect availability and uptake (Bradl, 2004). 
Cadmium is a non-essential element in plants and has no recognized physiological function. Cadmium has pronounced affects on plants at low concentrations. Natural environmental concentrations in non-polluted soils are $0.1 \mathrm{mg} / \mathrm{kg}$ and maximum concentration in plants is $0.2 \mathrm{mg} / \mathrm{kg}$ (Kirkham, 1977; Brooks, 1998). At higher exposures, adverse effects are the following: chlorosis, growth retardation, inhibition of photosynthesis, induction/inhibition of enzymes, altered stomatal function, water relations, interference with uptake and transport of macronutrients, and formation of free radicals (Prasad, 1995; Robinson et al., 2000). Nonhyperaccumulators have developed defense mechanisms to counteract high concentrations of $\mathrm{Cd}$ both inter-/extracellularly, including the accumulation of high concentrations of $\mathrm{Cd}$ in roots rather than transferring to the shoots, vacuolar sequestration, increased syntheses of phytochelatins and metallothioneins, and the upregulation of proteins that alleviate free radical oxidative damage (Das et al., 1998; Sanità di Toppi and Gabbrielli, 1999; Nan et al., 2002).

Zinc is a required element for the activity of many enzymes in plants, however Zn may by toxic in high concentrations (Nan et al., 2002). In plants, $\mathrm{Zn}$ is absorbed from the soil solution primarily as $\mathrm{Zn}^{2+}$ and then subsequently is translated to the shoots via the xylem (Broadley et al., 2007). As $\mathrm{Zn}$ is transferred from the rhizosphere, it enters via epidermal and cortical cells to the root xylem through a maze of cells linked by the plasmodesmata by symplastic or apoplastic pathways. A deficiency of $\mathrm{Zn}$ in plants leads to observed affects as chlorosis, necrosis, bronzing, rosetting, epinasty, and reduced growth (Marschner, 2002).

Zinc toxicity occurs in agricultural crops and native ecosystems as well as urban landscapes where anthropogenic inputs of $\mathrm{Zn}$ contaminate these soils. However, $\mathrm{Zn}$ is also available by the chemical and physical weathering of $\mathrm{Zn}$-enriched bedrock and soils. These sources are especially available in low-pH soils (Broadley et al., 2007). Symptoms observed in plants subject to high concentrations of $\mathrm{Zn}$ are stunted growth, reduced yield, Fe-deficiency induced chlorosis, and interference of phosphorous uptake (Marschner, 2002). Important mechanisms in alleviating $\mathrm{Zn}$ toxicity in plants include increased efflux across the plasma membrane, vacuolar compartmentalization, an increase low molecular weight organic acid production, altered root-to-shoot translocation, and increased accumulation in older leaves (Hall, 2001; Qin et al., 2007). Todeschini et al. (2011) observed the effects of $300 \mathrm{mg} / \mathrm{kg}$ soil 
concentration on the morphology and change in biochemistry in poplar leaves and noted the high alteration of leaf morphology, ultrastructure, and photosynthesis. This group also found that intercellular $\mathrm{Zn}$ was mostly found in the xylem and parenchyma cells, where an abundant increase of calcium oxalate crystals was observed in leaves of Zn treated plants, suggesting an increase in free $\mathrm{Ca}^{2+}$ ions following zinc accumulation to cell walls.

Both $\mathrm{Cd}$ and $\mathrm{Zn}$ have chemically similar behaviors in higher plants (Adriano, 2001). Cadmium is known to mimic the behavior of essential element $\mathrm{Zn}$ for its uptake, thus may affect physiological functions that $\mathrm{Zn}$ performs. Chaney et al. (1976) observed pronounced interactions between $\mathrm{Cd}$ and $\mathrm{Zn}$ in cadmium uptake and translocation in soybean, perhaps due to the nonselectivity of chelators that aid in these processes. Das et al. (1998) describes that the ratio of Cd to $\mathrm{Zn}$ in cellular tissues may induce and alter the binding characteristics of metallothionein affecting distribution and competition of other metalloenzymes essential in physiological and metabolic functions.

\subsection{Interactions of cadmium and zinc in soils and the environment}

Within terrestrial ecosystems fluxes of metals occur between four basic compartments including: atmospheric, organic, soil and parent material, and biological organisms (Adriano, 2001). Reactions and mechanisms controlling these exchanges between compartments include, but are not limited to: weathering, biological uptake, mineralization, uptake and release of gases, sorption, and aerosol transport and deposition. Biogeochemical cycling of nutrients and potential toxic elements follow various pathways between these compartments, and connect organisms to individual ecosystems to the entire biosphere.

Within the rhizosphere many complex interactions occur between soils and metals and these interactions control the fate and toxicity of metals in an ecosystem. Partitioning of metals in soil systems are controlled by an interactive processes that occur between soil constituents and biology (Bradl, 2004). The most available form of metals in soils exists within the soil solution, where metals are soluble free ions or complexed in pore water as inorganic or organic complexes. Here, movement of ions to plants for uptake occurs by diffusion or by mass flow 
driven by transpiration. Primary and secondary minerals may not only act as sources of metals, but may also function as active absorbing sites through ion exchange onto clay minerals, which have high surface areas that may act as binding sites depending on physiochemical properties of the soil (Brown et al., 1999). Decomposing products of plant and animal tissues, the soil organic matter, may also act as sink and source of metals due to the properties of functional groups of organic residues. Soil biomass is another factor within the rhizosphere that will affect metal biogeochemistry and is the actual living component of this environment, the plant roots, invertebrates, bacteria, fungi, and algae that act as binding sites. The last component is strongly physiochemically dependent and, under certain conditions ( $\mathrm{pH}$ and Eh driven), precipitates will form. These include precipitates of phosphate, carbonate, and sulfides. Interactions within any of these components will lead to alteration of bioavailability of metals within the biosphere.

Cadmium in the environment, if not a product of anthropogenic activity, is largely associated with $\mathrm{Zn}, \mathrm{Zn}-\mathrm{Pb}$, or $\mathrm{Pb}-\mathrm{Zn}-\mathrm{Cu}$ ores associated with parent materials. Once introduced into the rhizosphere, both in contaminated and native soils, $\mathrm{Cd}$ is relatively immobile (Adriano, 2001). This may only hold true in soils meeting certain physiochemical requirements. In low $\mathrm{pH}$ soils, $\mathrm{Cd}$ is quite mobile (Kirkham, 1977). General background concentrations of $\mathrm{Cd}$ in agricultural soils are $1 \mathrm{mg} / \mathrm{kg}$, however when observed in higher concentrations than $1 \mathrm{mg} / \mathrm{kg}$, these concentrations are derived from geologic formations and soils sourced from these formations, phosphate fertilizers and or atmospheric deposition (Koopmans et al., 2008; Sanità di Toppi and Gabbriellli, 1999). Major sites for Cd accumulation in soils have been associated with various forms of organic matter in both the solid and dissolved forms (Koeppe, 1977; Krishnamurti and Naidu, 2003; Akkajit and Tongcumpou, 2010). The functional groups of these materials are generally oxygen-containing functional groups, such as carboxylic acids and phenolic groups that form stable complexes with Cd (Krishnamurti and Naidu, 2003). Pueyo et al. (2003), using the modified BCR method, found that Cd was mostly bound to the exchangeable and weak acid soluble fraction, with extraction yields ranging between $25 \%$ to $75 \%$, depending on the soil and concentration.

In the environment, the primary inputs of $\mathrm{Zn}$ into soils are from the chemical and physical weathering of parent rocks (Broadley et al., 2007). Zinc occurs in minerals from 
nonspecific replacement of $\mathrm{Mg}$ and $\mathrm{Fe}$ with $\mathrm{Zn}$. Zinc concentration in agricultural soils from around the world range 10 to $200 \mathrm{mg} / \mathrm{kg}$ soil (Adriano, 2001). Zinc is most bioavailable in the water soluble form, especially in contaminated environments and remains in the upper most portion of the soil column (Černík et al., 1994). Secondary inputs of $\mathrm{Zn}$ in the environment are generally from anthropogenic activity, generally a result of smelting and mining. The content and distribution of $\mathrm{Zn}$ are linked to various processes and factors, such as weathering, organic matter and clay content, and $\mathrm{pH}$ (Adriano, 2001). Due to $\mathrm{Zn}$ being an essential element in photosynthesis and respiration, $\mathrm{Zn}$ is generally depleted in the soil column and translocated via complexation with organic ligands to the shoots via the xylem (Todeschini et al., 2011). Interactions between $\mathrm{Zn}$ and $\mathrm{Cd}$ in soils are known, the usual geochemical ratio is $1 \mu \mathrm{g} \mathrm{Cd:} 100$ $\mu \mathrm{g} \mathrm{Zn}$ found in most co-pollution environments, where $\mathrm{Zn}$ reduces $\mathrm{Cd}$ uptake more than reciprocal (Souza and Rauser, 2003; Chaney et al., 2007).

\subsection{Sequential extraction}

Toxicity of metals within the environment strongly depends on the form/compartment in which they occur. The use of sequential extraction has been paramount since its inception in the late 1970's (Tessier et al., 1979) in providing an indirect approach of describing how potential toxic metals are operationally defined by choice chemical extractants. Various instrumental techniques can be used to directly determine the content of contaminated soils, such as extended $\mathrm{X}$-ray absorption fine structure, however these methods are not generally available and may have poor detection limits in soils containing trace contents of the metal of interest. The alternative is to use indirect methods that may be more laborious, but are more readily available for the scientific community. In sequential extraction, reagents used are applied to the same sample to sub-divide the total metal content based on its extraction response. Numerous sequential extraction methods exist, leading to confusion when comparing results between methods (Bacon and Davidson, 2009). More recently, European scientists, collectively through the Standards, Measurements and Testing Program, have improved and optimized the sequential extraction method from the original protocol (the revised Bureau of Common References, "BCR" procedure). The revised sequential extraction method was developed by agency experts and tested and scrutinized by interlaboratory studies (Rauret et al., 1999). 
The revised sequential extraction protocol consists of three-steps of increasing extractability. Each step is associated with a nominal target phase, in which the reagent targets specific mineral phases. This protocol is outlined in Table 1.1. Step one includes the use of acetic acid to target exchangeable and water- and acid-soluble cations associated with carbonates or weakly bound to substrates. Step two targets the reducible fraction within the sample associated with Fe- and Mn-oxyhydroxides and this is accomplished using hydroxylamine hydrochloride buffered to a $\mathrm{pH}$ of 1.5 . Step three uses hydrogen peroxide digestion at $85^{\circ} \mathrm{C}$, followed by extraction with ammonium acetate that targets the oxidizable fraction associated with organic matter and sulfides. Residuum from previous steps is then subjected to aqua regia digestion, where this step has replaced previous methods of digestion of residuals using hydrofluoric acid. Each analyte of interest is summed from each step to determine total extracted, which is compared to accompanying, but separate, pseudo total extraction that is carried out by aqua regia digestion of the original sample.

Issues that surround sequential extraction may be as great as the information produced from these extractions. Many have concluded that the problems with sequential extraction are not only the difficulty with reproducibility, but also the non-selectivity of the extractants, the overwhelming potential for redistribution of analytes among phases during the extraction, incomplete extraction during steps, and the precipitation of new mineral phases during the extraction (Belzile et al., 1989; Bermond, 2001; Bacon and Davidson, 2009). Sequential extraction coupled with synchotron analysis is the only means of interpreting whether a specific trace metal binds to a specific substrate (Tipping et al., 1985; Scheckel et al., 2003, Wan et al., 2006). Tipping et al. (1985) showed that $\mathrm{Pb}$ redistributed between Mn-oxides to Fe-oxides in natural sediments from a former lead mine when treated with hydroxylamine hydrochloride. Wan et al. (2006) showed that redistribution of $\mathrm{Zn}, \mathrm{Cd}, \mathrm{Pb}$ and $\mathrm{Cu}$ in fly ash strongly depended on geochemical nature of sediments studied. It has also been suggested that $\mathrm{H}^{+}$consumption and pH may affect metal distribution (Bermond, 2001). Most extractants used are buffered to a low starting $\mathrm{pH}$, however by the time the reaction step is over, there is generally significant $\mathrm{pH}$ change. This evokes exchange reactions with soil components, dissolution of $\mathrm{CaCO}_{3}$, and reduction of $\mathrm{Mn}-$ and $\mathrm{Fe}-\mathrm{oxyhydroxides.} \mathrm{pH}$ change during these reactions has led scientists to 
believe that this phenomenon is indeed problematic, because such changes may cause these extractants to be non-selective and lead to high redistribution.

In plant and agricultural sciences, sequential extraction can be used as a proxy to measure what has been loosely defined as "bioavailable" to plants. The measurement of availability of either essential or toxic elements to plants through sequential extraction has been defined as the concentration determined for the exchangeable fraction (step 1) or the combination of steps 1 through 3 (Bacon and Davidson, 2009). Sequential extraction was mentioned in a review by Luster et al. (2008) as a qualifier to determine metal distribution and availability. Sequential extraction could be used as a comprehensive characterization of soil-bound elements that may show good correlation between extractability and plant uptake. Pueyo et al. (2003) used soil-toplant transfer factors, determined from the ratio of trace element concentration in plants versus concentrations found in soils where the plant was grown. This method was carried out for step 1 and the combination of step 1 and 2 of the revised BCR method, in addition a comparison to 0.01 and $1 \mathrm{~mol} \mathrm{~L}^{-1} \mathrm{CaCl}_{2}$ soil extractions. More recently, sequential extraction has been used to observe the effects of EDTA treatment "before" and "after" on uptake and fractionation by Taraxacum officinale (Massop et al., 2009). Massop et al. (2009) found that the sum of potential toxic elements in steps 1 through 3 poorly correlated to plant uptake, However, in regards to EDTA treatment, there was positive correlation between change in fractionation in the first step associated with soil washing process, in respect to the operationally defined fractions in the BCR protocol.

\subsection{Single extraction methods to determine bioavailability}

Using total concentration values in soil and water have proven misleading for determination of bioavailability, because only a small component of the total may really be available (Shan et al., 2003). The use of one-step single extraction methods for the determination of bioavailability has been popularly used to secure a measurement of the labile quantities of toxic and essential metals in soil samples. However, there is no universal single extraction method that is useful in determining bioavailability due to the heterogeneity and complexity of soils (Sauvé et al.. 2000). Very commonly used single extractions use aminopolycarboxylic 
acids, such as DTPA and EDTA (Lindsay and Norvell, 1978; Feng et al., 2005; Matúšs, 2007). Both of these complexing agents show similar extraction efficiency, but may over-represent the amount of metal transferred from the soil to the plant depending on soil characteristics and properties. Feng et al. (2007) found in rhizosphere soils that both DTPA and EDTA were good indicators for root and shoot content of barley for $\mathrm{Zn}$, but poor for $\mathrm{Cd}$, where a cocktail of organic acids (acetic, lactic, citric, malic, formic acids), noted as the "rhizosphere-based method", was a good predictor of $\mathrm{Zn}$ and $\mathrm{Cd}$ contents from soils transferred to roots and shoots of barley in four types of soils used.

The use of low molecular weight organic acids (LMWOAs) has proven to simulate, and be more effective indicators of, rhizosphere availability. The primary source of organic acids is roots, which exude a broad array of $\mathrm{C}$-containing compounds, many of which are responsive to metals in the rhizosphere (Jones, 1998; Jones et al. 2003). Secondary sources of organic acids in the rhizosphere are produced from the excretion from microorganisms during breakdown of other C substrates (Jones, 1998). With this consideration, it is not out of the question to use single- or a cocktail of organic acids to measure labile concentrations of metals. Meers et al. (2007) found that $0.11 \mathrm{M}$ acetic acid extracted the same concentration as the first-step of the revised $\mathrm{BCR}$ sequential extraction method, finding it more effective at determining relative $\mathrm{Cd}$ extractability in acidic, silty sandy soil types. Shan et al. (2003) suggested a similar method to that of Feng et al. (2005) (the rhizosphere-based method), using a cocktail of organic acids (>10 $\mathrm{mM}$ ) to gain a more realistic conditions encountered in the rhizosphere.

\subsection{Phytoremediation}

Phytoremediation is a multifunctional approach to introduce plants into contaminated environments and allows plants to assimilate toxic substances into their biomass. There are three main strategies in phytoremediation: phytoextraction, rhizofiltration, and phytostabilization (McIntyre, 2003). McGrath et al. (2001) describe several approaches used in phytoremediation: (1) Use of hyperaccumulators that have tendencies to absorb higher than normal concentrations;

(2) Use of high biomass crops that can be aided in extracting higher amounts of metals through the use of chemical extractants, such as EDTA; and (3) Use of fast growing trees that are easily 
harvestable and maybe economically beneficial for alternative energies such as Populus and Salix.

Phytoextraction largely depends on the sequestration of toxic elements within the above ground portion of the accumulating plant per surface area. Hyperaccumulators (i.e., Thlaspi caerulescens) generally are not necessarily the best candidate for phytoextraction because of high metal concentration in plant is most often negatively correlated to plant growth (Lebeau, 2008). High biomass with significant concentrations per surface area with allowance for multiple harvests per year may serve as a better candidate for phytoextraction. Phytostabilization functions as a means to prevent further disruptive actions on the environment, and renders harmful toxins inert by changing their chemical speciation by sequestration through organic acid precipitation or other dissolved organic matter or substances exuded by plants. Plants grown under these conditions may not even remove much or any contamination, but aid in regenerating soils if they can tolerate and grow under these elevated conditions (McIntyre, 2003). A limitation of phytostabilization is the extensive use of fertilizers or extensive soil modification using amendments to help aid growth and stabilization capabilities (Gratão et al., 2005).

Chemical additions of synthetic amino polycarboxylic acids have been used in phytoremediation to promote uptake in plants (Cooper et al., 1999; Robinson et al., 2000; Grčman et al., 2001; Evangelou et al., 2007). Robinson et al. (2000) found that the addition of EDTA, DTPA, and NTA to poplar clones caused a temporary increase in uptake of cadmium, however the additions of $2000 \mathrm{mg} / \mathrm{kg}$ EDTA and $500 \mathrm{mg} / \mathrm{kg}$ NTA treatments resulted in significant growth reduction and abscission of leaves. Chelate assisted phytoremediation works best in conditions where metals of interest have low bioavailability, allowing the establishment of large biomass before the chemical is added (McGrath et al., 2002). The use of synthetic chelates has high potential risks associated with leaching, residence time in soil, and effects on soil biota (Gratão et al., 2005). A more effective alternative to chemical chelates may be the enhanced understanding of rhizosphere processes and use of microbes that work synergistically with the host to promote the removal and or sequestration of toxic metals (Donnelly and Entry, 1999; Meharg and Cairney, 2000; Wenzel, 2009). 


\subsection{Lehigh Gap Wildlife Refuge and Nature Center and Palmerton Zinc Superfund Site}

The Lehigh Gap Wildlife Refuge and Nature Center location that was chosen for this study is located in the Borough of Palmerton, Carbon County, Pennsylvania. Approximately 30 kilometers northwest from Borough of Allentown, PA, the Lehigh Gap Wildlife Refuge and Nature Center is situated on the western side of Lehigh Water Gap on Blue Mountain at the confluence of the Lehigh River with Aquashicola Creek (Figures 1.1-1.4). Smelting of zinc ore had been the major industry within this valley from the early 1890's until its declaration as a Superfund site in the early 1980's. Two facilities deemed the West and East Plants once owned by New Jersey Zinc Company had produced zinc and other metals for machinery, pharmaceuticals, pigments and many other products. During the operation of these smelters and associated facilities, huge quantities of zinc, lead, cadmium, and sulfur dioxide had been aerially emitted, leading to the defoliation of nearly 2,000 acres on Blue Mountain (USEPA, 1987). The main objectives set by the USEPA to ameliorate the site are: (1) Minimize direct contact with contaminated soils; (2) Reduce runoff; (3) Reduce contamination in runoff; and (4) Mitigate environmental damage.

Since the original Record of Decision (ROD) by the USEPA (1987), extensive efforts have been made to use the best available technologies and practices to remediate the site (USEPA, 2002). These include application of biosolids to vegetate the north slope of Blue Mountain nearest to the East Plant, minimizing both runoff from the Cinder Bank adjacent to East Plant and off of Blue Mountain, controlling runoff and leachate formation from the Cinder Bank to protect surface- and ground-water, installation of a vegetative barrier on the Cinder Bank to reduce windborne contaminated emissions and erosion, water quality improvement by creating "metal removal zones" that are pits lined with iron rich materials to interact with incipient runoff, and the creation artificial wetlands to filter runoff from both the Cinder Bank and Blue Mountain. Control of runoff was deemed critical because of findings that most contamination exists within the top 6 to 10 inches and mostly bound to organic matter preventing the downward movement of metals. In the ROD from 1987, five samples sites on Blue Mountain were selected and analyzed for the metals mentioned above. In these samples, recorded levels of cadmium ranged from 364 to $1,300 \mathrm{mg} / \mathrm{kg}$, lead from 1,200 to $6,475 \mathrm{mg} / \mathrm{kg}$, and zinc from 13,000 to $35,000 \mathrm{mg} / \mathrm{kg}$. All of these samples exceed background levels 100-to 1000-fold. 
In early 2002, talks began to purchase the land that is now the Lehigh Gap Wildlife Refuge and Nature Center. By 2003, the three properties that encompass the 750-acre site had been purchased. Subsequently following the purchase, work began on habitat restoration and management of the ecological damaged portion of the refuge. Since efforts have been placed on remediating this area, tremendous headway has been made using native vegetation and sustainable practices in ameliorating soil conditions to promote revegetation that have produced good quality habitat on about 75 acres (Latham et al., 2007) by planting 56 one-acre plots by tractor and spreader that have since converged into one large plot. A USDA NRCS Soils Map with sampling locations is included in Figure 1.4. In the summer months of 2006, further work was done to seed the steep slopes up along the ridge by aerial application of fertilizer, lime, and seed. By July of 2006, the entire area once considered degraded had been reclaimed, placing the partnership between government agencies, private parties, and the organizers of the Refuge for recognition and holding up the accomplishments as a national example (Hoopes, 2007). With continued success since its inception in 2002, the site has completely metamorphosed from a barren wasteland into an interactive outdoor laboratory that services the community and draws continued interest from universities to state and federal government.

The Lehigh Gap Wildlife Refuge and Nature Center was chosen because of the unique opportunities for ecological restoration activities. Studies of heavy metal contamination in soil and plant tissues are of great interest due to contaminant transport within the biosphere. Soils from this site met the criteria for observing the effects of mycorrhizal inoculation and plant growth on soil chemistry and fractionation. Four locations from this site were used in this study and photography of sampling locations can be seen in Figure 1.5.

\subsection{Purpose of this study}

The first component of this study determined the extractable amount of both $\mathrm{Cd}$ and $\mathrm{Zn}$ in soil samples collected from Lehigh Gap Wildlife Refuge and Nature Center using common single extraction methods (i.e., RBM, EDTA, DTPA, Mehlich-III, $\mathrm{H}_{2} \mathrm{O}$ ) and compared these to extractability of collected fungal liquid media (modified Melin-Norkrans) grown with Paxillus involutus. Additionally, these single extraction methods were compared against the first fraction 
of the modified BCR sequential extraction method, commonly used to determine the bioavailable component in soils of interest and the pseudototal, an estimate of the total content of the metal of interest. The modified BCR sequential extraction method was used to fully characterize the chemical fractionation of these soils. The goal was to characterize and identify the availability of $\mathrm{Cd}$ and $\mathrm{Zn}$ in these soils and assess the effectiveness of rhizosphere based method or synthetic amino polyaminecarboxylic acids as representative extractants relative to that of the collected fungal media grown with Paxillus involutus.

The second component of this study was to grow a Populus hybrid with and without Paxillus involutus inoculants in two Lehigh Gap Wildlife Refuge and Nature Center soils, "amended" and "non-amended" as part of reclamation activities. Along with plant growth, metal content and leachate measurements, chemical fractionation of these soils were determined to observe the difference from "before" and "after" growth. The purpose of this component is to observe the success of plant growth in these two different soils and the short-term change in chemistries of these soils due to the interactions with both fungi and Populus growing symbiotically. This may aid in decision making associated with future reforestation projects at the LGWR and its temporary effects on the availability of both cadmium and zinc.

\subsection{References}

Adriano DC. Trace elements in terrestrial environments: biogeochemistry, bioavailability, and risks of metals. $2^{\text {nd }}$ Edition, New York, Springer-Verlag; 2001.

Akkajit P, Tongcumpou C. Fractionation of metals in cadmium contaminated soil: relation and effect on bioavailable cadmium. Geoderma 2010; 156: 126-132.

Alkorta I, Hernández-Allica J, Becerril JM, Amezaga I, Albizu I, Garbisu C. Recent findings on the phytoremediation of soils contaminated with environmentally toxic heavy metals and metalloids such as zinc, cadmium, lead, and arsenic. Reviews in Environmental Science Biotechnology 2004; 3: 71-90.

Bacon JR, Davidson CM. Is there a future with sequential chemical extraction? Analyst 2008; 133: 25-46.

Bellion M, Courbot M, Jacob C, Blaudez D, Chalot M. Extracellular and cellular mechanisms sustaining metal tolerance in ectomycorrhizal fungi. Federation of European Microbiological Societies Microbiological Letters 2006; 254: 173-181.

Belzile N, Lecomte P. tessier A. Testing readsorption of trace elements during partial chemical extraction of bottom sediments. Environmental Science Technology 1989; 23: 17291736. 
Bermond A. Limits of sequential extraction procedures re-examined with emphasis on the role of $\mathrm{H}^{+}$ion reactivity. Analytica Chimica Acta 2001; 445: 79-88.

Blaudez D, Bottom B, Chalot M. Cadmium uptake and subcellular compartmentalization in the ectomycorrhizal fungus Paxillus involutus. Microbiology 2000; 146: 1109-1117.

Bradl HB. Adsorption of heavy metal ions on soils and soil constitutents. Journal of Colloid and Interface Science 2004; 277: 1-18.

Broadley MR, White PJ, Hammond JP, Zelko I, Lux A. Zinc in Plants. New Phytologist 2007; 173: 677-702.

Brooks RR. Plants that hyperaccumulate heavy metals. Wallingford, UK, CAB International: 1998.

Brown GE, Foster AL, Ostergren JD. Mineral Surfaces and Bioavailability of Heavy Metals: A Molecular-Scale Perspective. Proceedings of the National Academy of Sciences of the United States of America 1999; 96: 3388-3395.

Černík M, Federer P, Borkovec M, Sticher H. Modeling Heavy Metal Transport a Contaminated Soil. Journal of Environmental Quality 1994; 23: 1239-1248.

Chaney RL, White MC, van Tienhoven M. Interaction $\mathrm{Cd}$ and $\mathrm{Zn}$ in phytotoxicity and uptake by soybean. Agronomy (Abstract), 21.

Chaney RL, Angle JS, Broadhurst CL, Peters CA, Tappero RV, Sparks DL. Improved understanding of hyperaccumulation yields commercial phytoextraction and phytomining technologies. Journal of Environmental Quality 2007; 36: 1429-1443.

Cooper EM, Sims JT, Cunningham SD, Huang JW, Berti WR. Chelate-assisted phytoextraction of lead from contaminated soils. Journal of Environmental Quality 1999; 28: 1709-1719.

Courbot M, Diez L, Ruotolo R, Chalot M, Leroy P. Cadmium-Responsive Thiols in the Ectomycorrhizal Fungus Paxillus involutus. Applied and Environmental Microbiology 2004; 70: 7413-7417.

Das P, Samantaray S, Rout GR. Studies on cadmium toxicity in plants: A review. Environmental Pollution 1998; 98: 29-36.

Donnelly PK, Entry JA. Bioremediation of soils with mycorrhizal fungi. In Bioremediation of Contaminated Soils. Agronomy Monograph no. 37. Madison, WI., American Society of Agronomy, Crop Science Society of America, Soil Science Society of America; 1999.

Evangelou MWH, Ebel M, Schaeffer A. Chelate assisted phytoextraction of heavy metals from soil. Effect, mechanism, toxicity, and fate of chelating agents. Chemosphere 2007; 68: 989-1003.

Feng M, Shan X, Zhang S, Wen B. A comparison of the rhizosphere-based method with DTPA, EDTA, $\mathrm{CaCl}_{2}$, and $\mathrm{NaNO}_{3}$ extraction methods for prediction of bioavailability of metals in soil to barley. Environmental Pollution 2005; 137: 231-240.

Formina M, Charnock JM, Hiller S, Alexander IJ, Gadd GM. Zinc Phosphate Transformations by the Paxillus involutus/Pine Ectomycorrhizal Association, Microbial Ecology 2006; 52: 322-333.

Frey B, Keller C, Zierold K, Schulin R. Distribution of Zn in functionally different leaf epidermal cells of the hyperaccumulator Thlaspi caerulescens. Plant, Cell, and Environment 2000; 23: 675-687.

Gadd GM. Interactions of fungi with toxic metals. New Phytologist 1993; 124: 25-60.

Gadd GM. Metal Transformations. In: Gadd GM, editor. Fungi in bioremediation. New York: Cambridge University Press; 2001. p. 359-382. 
Galli U, Schüepp H, Brunold C. Heavy metal binding by mycorrhizal fungi. Physiologia Plantarum 1994; 92: 364-368.

Godbold DL, Jentschke G, inter S, Marschner P. Ectomycorrhizas and amelioration of metal stress in forest trees. Chemosphere 1998; 36: 757-762.

Gratão PL, Prasad MNV, Cardoso PF, Lea PJ, Azevedo RA. Phytoremediation: green technology for the clean up of toxic metals in the environment. Braz. J. Plant Physiol. 2005; 17: 53-64.

Grčman H, Velikonja-Bolta Š, Vodnik D, Kos B, Leštan D. EDTA enhanced heavy metal phytoextraction: metal accumulation, leaching and toxicity. Plant Soil 2001; 235: 105114.

Hall JL. Cellular mechanisms for heavy metal detoxification and tolerance. Journal of Experimental Botany 2002; 53: 1-11.

Hartley J, Cairney JWG, Meharg AA. Do mycorrhizal fungi exhibit adaptive tolerance to potentially toxic metals in the environment? Plant Soil 1997; 189: 303-319.

Hoopes RE. A Dream Come True. Wildlife Activist 2002.

Jaeckel P, Krauss GJ, Krauss G. Cadmium and zinc response of fungi Heliscus lugdunensis and Verticullium cf. alboatrum isolated from highly polluted water. Science and the Total Environment 2005; 346: 274-279.

Jentschke G, Godbold DL. Metal toxicity and ectomycorrhizas. Physiologia Plantarum 2000; 109: 107-116.

Jones DL. Organic acids in the rhizosphere - a critical review. Plant Soil 1998; 205: 25-44.

Jones DL, Dennis PG, Owen AG, van Hees PAW. Organic acid behavior in soils misconceptions and knowledge gaps. Plant Soil 2003; 248: 31-41.

Kabata-Pendias A. Soil-plant transfer of trace elements - an environmental issue. Geoderma 2004; 122: 143-149.

Kirkham MB. Uptake of barley of water table-or surface-applied cadmium. Soil Science Society of America Journal 1977; 41: 1125-1129.

Kirkham MB. Cadmium in plants on polluted soils: Effects of soil factors, hyperaccumulation, and amendments. Geoderma 2006; 137: 19-32.

Koeppe DE. The uptake, distribution, and effect of cadmium and lead in plants. Science and the Total Environment 1977; 7: 197-206.

Koopmans GF, Römkens PFAM, Fokkema MJ, Song J, Luo YM, Japenga J, Zhao FJ. Feasibility of phytoremediation to remediate cadmium and zinc contaminated soils. Environmental Pollution 2008; 156: 905-914.

Krishnamurti GSR, Naidu R. Solid-solution equilibria of cadmium in soils. Geoderma 2003; 113: $17-30$.

Latham RE, Steckel DB, Harper HM, Steckel C, Boatright M. Lehigh Gap Wildlife Refuge Ecological Assessment - For the Lehigh Gap Nature Center, Slatington, Pennsylvania. Pennsylvania. Natural Lands Trust, Continental Conservation, Botanical Inventory: 2007.

Lebeau T, Braud A, Jézéquel K. Performance of bioaugmentation-assisted phytoextraction applied to metal contaminated soils: A review. Environmental Pollution 2008; 153: 437522.

Lindsay WL, Norvell W. Development of a DTPA test for Zinc, Iron, Manganese, and Copper. Soil Science Society of America Journal 1978; 42: 421- 428.

Luster J, Menon M, Hermle S, Schulin R, Goerg-Günthardt MS, Nowack B. Initial changes in refilled lysimeters built with metal polluted topsoil and acidic or calcareous subsoils as 
indicated by changes in drainage water composition. Water, Air, Soil Pollution Focus 2008; 8: 163-176.

Marschner H. Mineral Nutrition in Higher Plants. $2^{\text {nd }}$ Edition, London, Academic Press; 2002.

Massop KF, Davidson CM, Ure AM, Shand CA, Hillier SJ. Effect of EDTA on the fractionation and uptake by Taraxacum officinale of potential toxic elements in soil from former chemical manufacturing sites. Plant Soil 2009; 320: 117-129.

Matúš P. Evalutaion of separation and determination of phytoavailable and phytotoxic aluminium species fractions in soils, sediment and water samples by fiver different methods. Journal of Inorganic Biochemistry 2007; 101: 1214-1223.

McIntyre T. Phytoremediation of heavy metals from soils. In: Tsao DT, editor. Phytoremediation, Advances in Biochemical Engineering Biotechnology, Vol 78. New York: Springer-Verlag; 2003. p. 98-123.

McGrath SP, Zhao FJ, Lombi E. Plant and rhizosphere process involved in phytoremediation of metal-comtaminated soils. Plant Soil 2001; 232: 207-214.

McGrath SP, Zhao FJ, Lombi E. Phytoremediation of metals, metalloids and radionuclides. Advanced Agronomy 2002; 75: 1-56.

Meers E, Du Laing G, Unamuno V, Ruttens A, Vangronsveld J, Tack FMG, Verloo MG. Comparison of cadmium extractability from soils by commonly used single extraction protocols. Geoderma 2007; 141: 247-259.

Meharg AA, Cairney JWG. Ectomycorrhizas-extending the capacities of rhizosphere remediation. Soil Biology and Biochemistry 2000; 32: 1475-1484.

Meharg AA. The mechanistic basis of interactions between mycorrhizal associations and toxic metal cations. Mycological Research 2003; 107: 1253-1265.

Nan Z, Li J, Zhang J, Cheng G. Cadmium and zinc interactions and their transfer in soil-crop system under actual field conditions. The Science of the Total Environment 2002; 285: 187-195.

Noctor G, Arisi ACM, Jouanin L, Kunert KJ, Rennenberg H, Foyer CH. Glutathione: Biosynthesis, metabolism and relationship to stress tolerance explored in transformed plants. Journal of Experimental Botany 1998; 49: 623-647.

Prasad MNV. Cadmium toxicity and tolerance in vascular plants. Environmental and Experimental Botany 1995; 35: 525-545.

Prasad MNV. Heavy metal stress in plants: from molecules to ecosystems. $2^{\text {nd }}$ Edition, Heidelberg Narosa New Dehli, Springer-Verlag; 2004.

Pueyo M, Sastre J, Hernández E, Vidal M, López-Sánchez JF, Rauret G. Prediction of Trace Element Mobility in Contaminated Soils by Sequential Extraction. Journal of Environmental Quality 2003; 32: 2054-2066.

Qin R, Hirano Y, Brunner I. Exudation of organic acid anions from poplar roots after exposure to $\mathrm{Al}, \mathrm{Cu}$, and Zn. Tree Physiology 2007; 27: 313-320.

Rauret G, López-Sánchez JF, Sahuquillo A, Rubio R, Davidson C, Ure A, Quevaviller Ph. Improvement of the BCR three step sequential extraction procedure prior to the certification of new sediment and soil reference materials. Journal of Environmental Monitoring 1999; 1: 57-61.

Robinson BH, Mills TM, Petit D, Fung LE, Green SR, Clothier BE. Natural and induced cadmium-accumulation in poplar and willow: Implications for phytoremediation. Plant and Soil 2000; 227: 301-306. 
Sanità di Toppi L, Gabbrielli R. Response to cadmium in higher plants. Environmental and Experimental Botany 1999; 41: 105-130.

Sauvé S, Manna S, Turmel MC, Roy AG, Courchesne F. Solid-solution partitioning of Cd, $\mathrm{Cu}$, $\mathrm{Ni}, \mathrm{Pb}$, and $\mathrm{Zn}$ in organic horizons of a forest soil. Environmental Science and Technology 2003; 37: 5191-5196.

Scheckel KG, Impellitteri, Ryan JA, McEvoy T. Assessment of a Sequential Extraction Procedure for Perturbed Lead-Contaminated Samples with and without Phosphorus Amendments. Environmental Science and Technology 2003; 37: 1892-1898.

Schützendübel A, Polle A. Plant responses to abiotic stresses: heavy metal-induced oxidative stress and protection by mycorrhization. Journal of Experimental Botany 2002; 53: 13511365.

Shan X, Wang Z, Wang W, Zhang S, Wen B. Labile rhizosphere soil solution fraction for prediction of bioavailability of heavy metals and rare earth elements to plants. Analytical and Bioanalytical Chemistry 2003; 375: 400-407.

Souza JF, Rauser WE. Maize and radish sequester excess cadmium and zinc in different ways. Plant Science 2003; 165: 1009-1022.

Tessier A, Campbell PGC, Bisson M. Sequential Extraction Procedure for the Speciation of Particulate Trace Metals. Analytical Chemistry 1979; 51: 844-851.

Tipping E, Hetherington NB, Hilton J. Artifacts in the use of selective chemical extraction to determine distributions of metals between oxides of manganese and iron. Analytical Chemistry 1985; 57: 1944-1946.

Todeschini V, Lingua G, D’Agostino G, Carniato F, Roccotiello E, Berta G. Effects of high Zinc concentration in poplar leaves: A morphological and biochemical study. Environmental Experimental Botany 2011; 71: 50-56.

USEPA. Palmerton Zinc Superfund Site Blue Mountain Project, Summary of RI/FS Results. Philadelphia: USEPA Region III; 1987. p. 1-85.

USEPA. Second Five-year Review Report - Palmerton Zinc Pile Superfund Site. Philadelphia: USEPA Region III: 2002. p. 1-100.

Wan X, Wang W, Ye T, Guo Y, Gao X. A Study on the Chemical and Mineralogical Characterization of MSWI Fly Ash Using a Sequential Extraction Procedure. Journal of Hazardous Materials 2006; 134: 197-201.

Wenzel WW. Rhizosphere processes and management in plant-assisted bioremedation (phytoremediation) of soils. Plant Soil 2009; 321: 385-408. 
Table 1.1 Revised BCR Sequential Extraction Protocol

\begin{tabular}{|c|c|c|c|}
\hline Fraction & Chemical & Fraction Label & Nominal Target \\
\hline Step 1 & $0.11 \mathrm{M}$ Acetic Acid & $\begin{array}{l}\text { Exchangeable/Water } \\
\text { and acid-soluble }\end{array}$ & $\begin{array}{c}\text { Soluble and } \\
\text { exchangeable cations } \\
\text { and carbonates }\end{array}$ \\
\hline Step 2 & $\begin{array}{l}\text { 0.1 M Hydroxylamine } \\
\text { Hydrochloride }\end{array}$ & Reducible & $\begin{array}{c}\text { Fe- and Mn } \\
\text { oxyhydroxides }\end{array}$ \\
\hline Step 3 & $\begin{array}{c}\text { 8.8 M Hydrogen } \\
\text { Peroxide/1 M } \\
\text { Ammonium Acetate }\end{array}$ & Oxidizable & $\begin{array}{c}\text { Organic matter and } \\
\text { sulfides }\end{array}$ \\
\hline Step 4 & Aqua Regia & Residual & \\
\hline
\end{tabular}






Figure 1.1 Satelite Imagery illustrating Palmerton Borough Vicinity and LGWR 


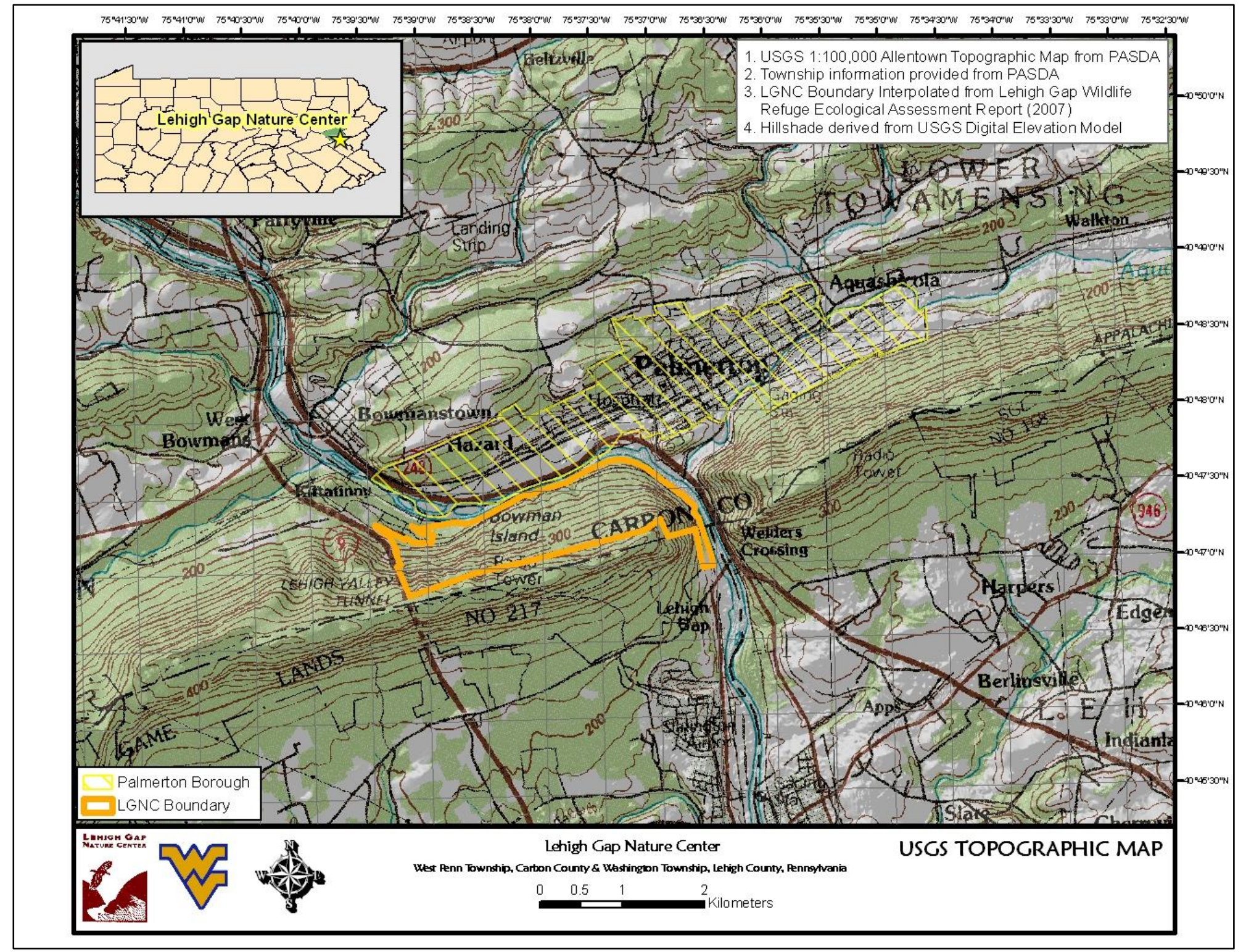

Figure 1.2 USGS 1:100,000 Allentown Topographic Map illustrating Palmerton Borough and LGWR 


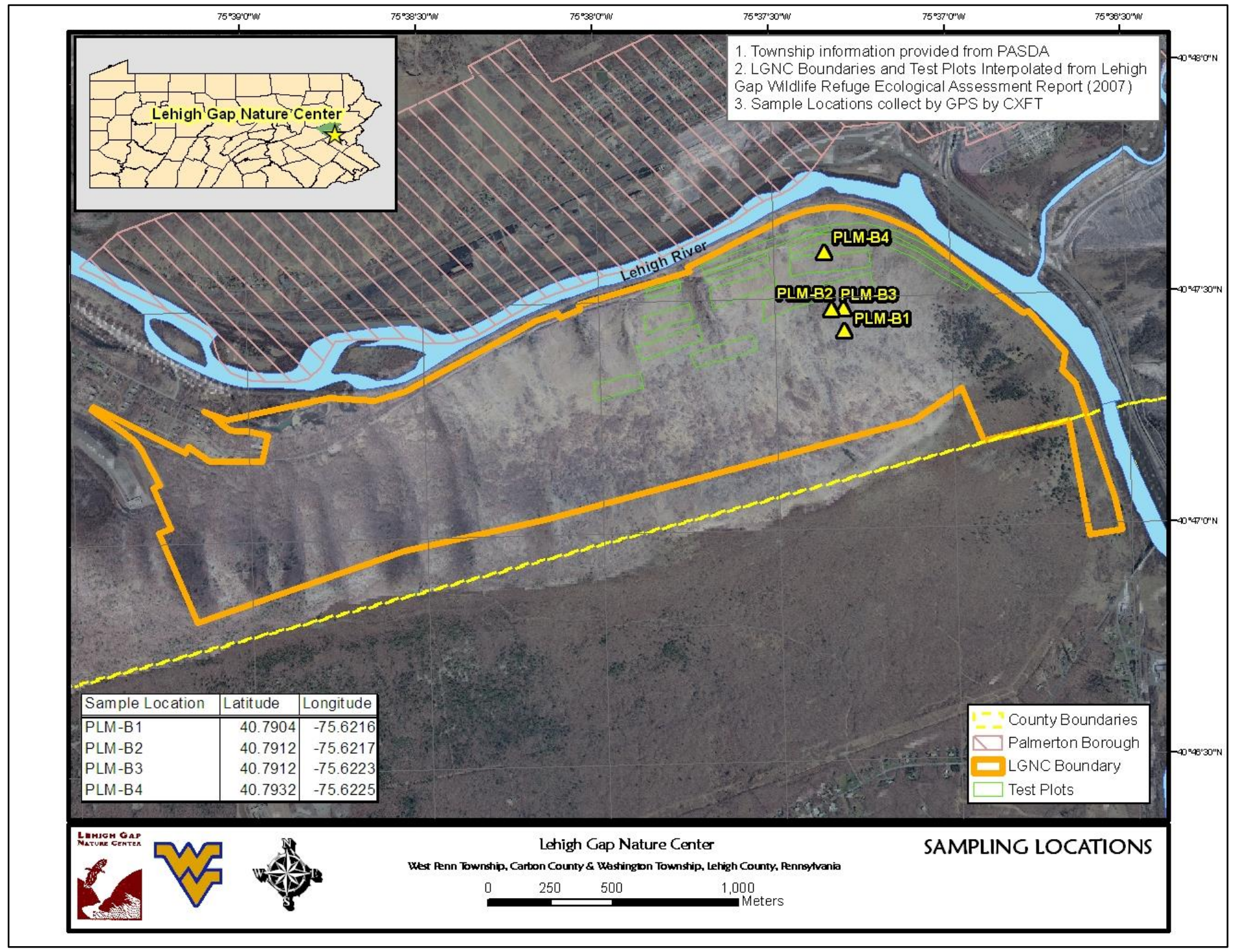

Figure 1.3 Satellite Image Illustrating Sampling Locations at LGWR 


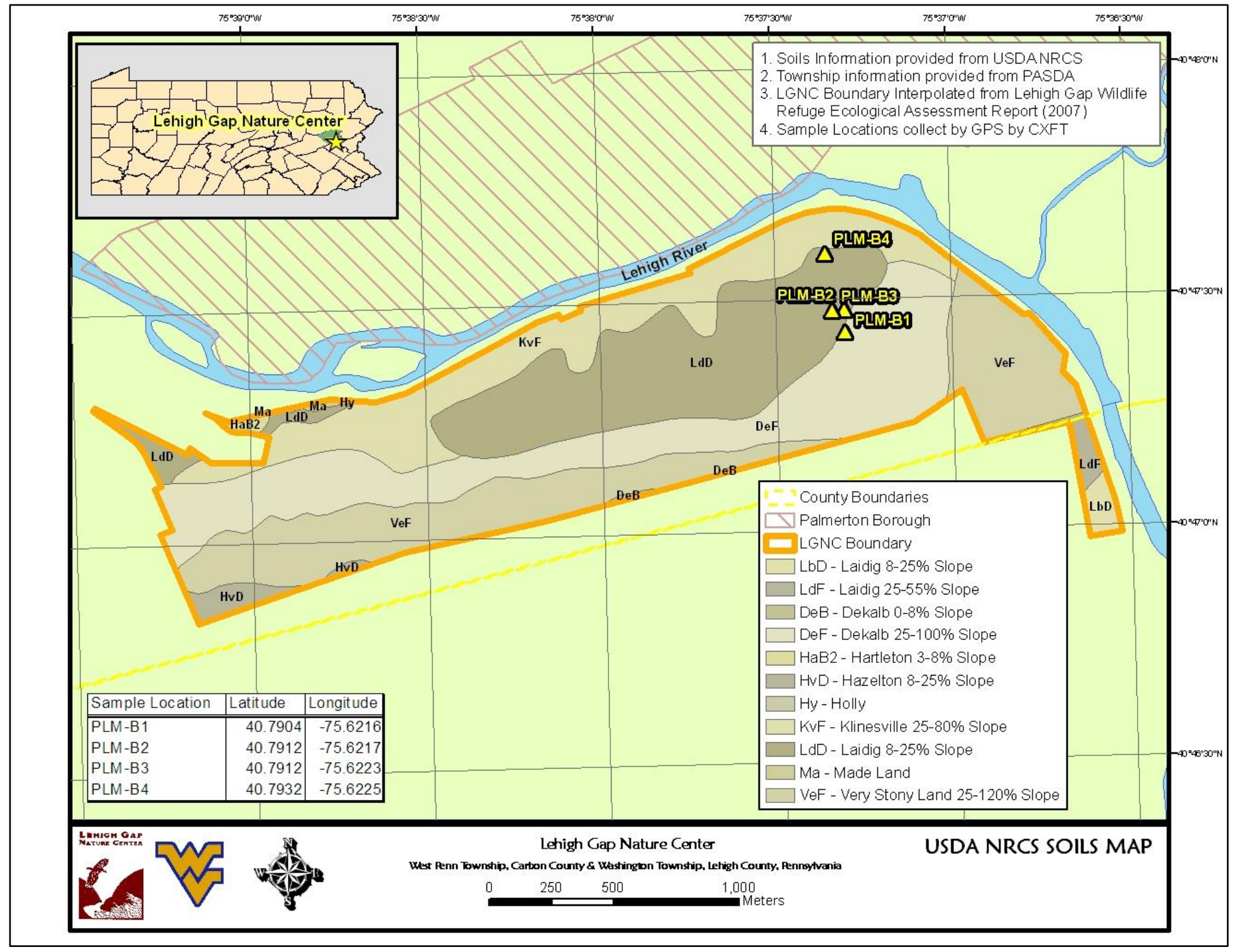

Figure 1.4 USDA NRCS Soils Map with Sampling Locations at LGWR 


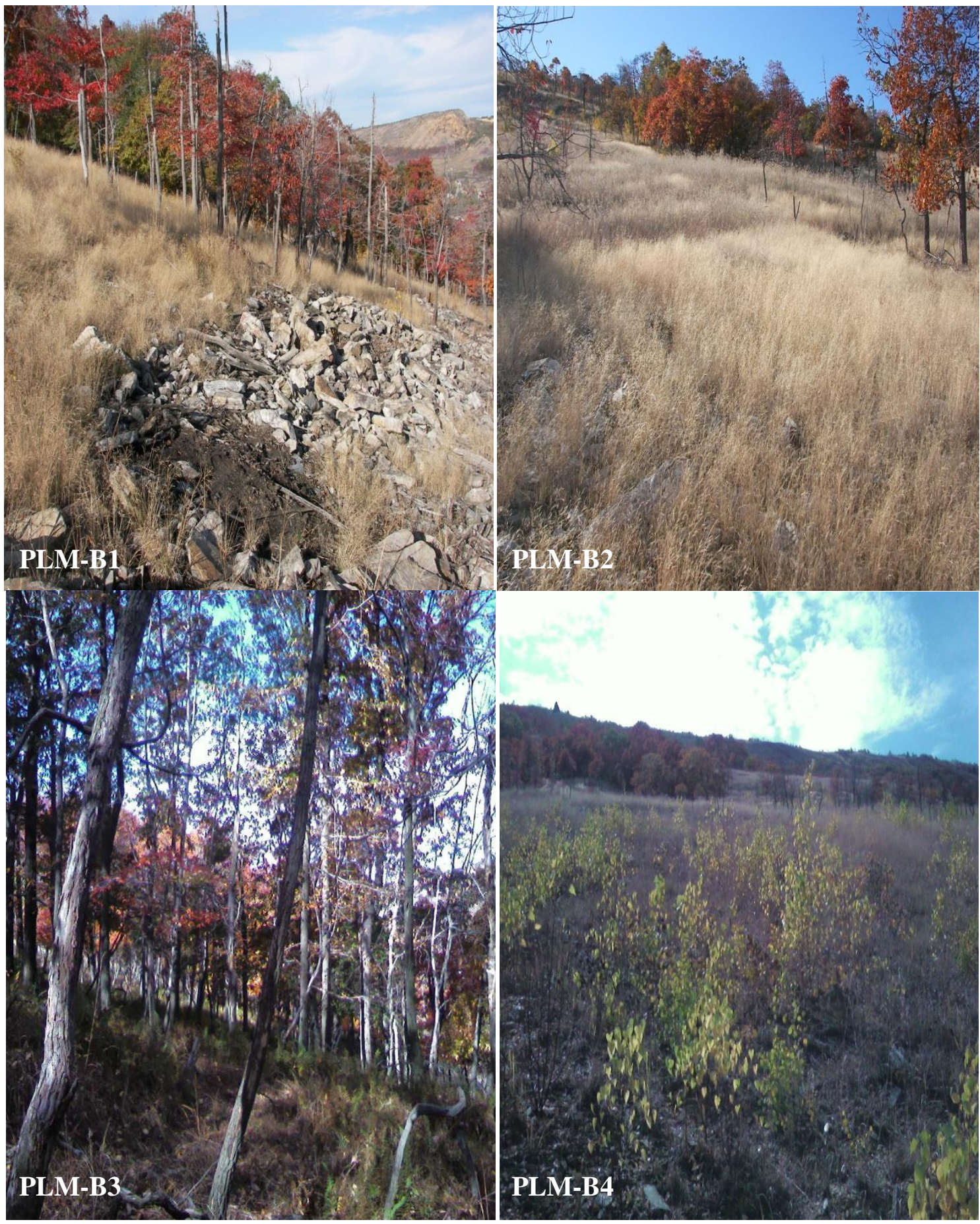

Figure 1.5 Photography of Sampling Locations at Lehigh Gap Nature Center/Wildlife Refuge, Palmerton, PA, USA. 


\section{Cadmium and zinc partitioning in zinc smelter contaminated soils}

\subsection{INTRODUCTION}

Contamination of soils by metals is a significant problem throughout the world. Agricultural, industrial, mining/smelting, and military activities increase the concentrations of zinc ( $\mathrm{Zn}$ ), cadmium (Cd), and other metals in soils (Pierzynsky and Schwab, 1993; Cunningham and Ow, 1996; Giller et al. 1998), which lead to broad ranging disruptions to plant community structure and function (Frey et al., 2006; Gallagher et al., 2008). At toxic concentrations, metals may eliminate a majority of the existing vegetation, leading to significant erosion of soil, loss of wildlife habitat, loss of carbon sequestration capacity, and loss of aesthetic appeal.

The evaluation of bioavailability of potentially toxic elements in environmental samples is of great interest to researchers and land managers in determining potential harm to humans and ecosystems. Although the total concentration of a metal in soils does not reflect its bioavailability, no universal method exists for predicting potential exposure and toxicity of metals in soils (Shan et al., 2003; Feng et al., 2005; Soriano-Disla et al., 2010). Traditional methods of testing soils include the use of single and sequential extraction procedures to assess availability to plants and potential for groundwater contamination. One-step extraction methods are frequently used to procure soil metal concentrations due to ease of operation and their procedural simplicity (Feng et al., 2005). These tests include the use of salts, organic acids, and/or synthetic organic chelates to promote the solubilization and mobility of metals within these samples for subsequent analyses.

Synthetic aminopolycarboxylic acids, such as diethylenetriaminepentaacetic acid (DTPA) and ethylenediaminetetraacetic acid (EDTA), have been employed in many studies to evaluate/interpret bioavailability of metals in environmental samples and enhanced uptake by plants (Lindsay and Norvell, 1979; Norvell, 1984; Heil et al., 1999; Feng et al., 2005; Evangelou et al., 2007; Leštan et al., 2008). The basis for the use of these synthetic chelates originates from the ease at which these compounds form soluble complexes with free metal ions, although many 
factors including lability of metals in soil, extractant concentration, interactions between metals and other ions, $\mathrm{pH}$, and soil matrix may affect extraction efficiency (Sun et al., 2001).

The activity plants and microbes residing on metal-contaminated soils influences metal mobility and partitioning in the rooting zone (Awad and Römheld, 2000; Degryse et al., 2008; Quartacci et al., 2009). Plants species and/or genotypes may differentially absorb and accumulate metals and may differentially release metal-chelating compounds into the rhizosphere (Hall, 2002; Panda and Matsumoto, 2007). Further, plants may preferentially form symbiotic associations with arbuscular mycorrhizal (AM) and/or ectomycorrhizal (ECM) fungi, which may produce a suite of novel compounds that also alter metal biogeochemistry (Wang et al., 2007; Cornejo et al., 2008; Johansson et al. 2008; Mrnka et al., 2012). These ubiquitous mycorrhizal associations may modify metal availability in soils due to biosorption to fungal hyphae, the production of metal-chelating fungal compounds, or altered uptake and cycling by host plants (Khan et al., 2000; Seguel et al., 2013). These changes will affect the availability and ecosystem flux of metals.

Using low molecular weight organic acids that are generally produced by plants and mycorrhizal fungi may better simulate conditions at the root-soil interface and provide an approach to determining metal bioavailability (Feng et al., 2005; Soriano-Disla et al., 2013). To our knowledge, evaluation of the influence of exudates produced by mycorrhizal fungi on metal availability or partitioning in soils has not been evaluated. In this study, we present the results from single-batch soil extractions to assess the bioavailability of $\mathrm{Cd}$ and $\mathrm{Zn}$ in soils collected from an abandoned zinc-smelter site. We compare $\mathrm{Cd}$ and $\mathrm{Zn}$ extractions using ECM fungal exudates from Paxillus involutus with those using EDTA, DTPA, the rhizosphere-based method (RBM), and Mehlich-III extraction methods in prediction of bioavailability. In conjunction, we also compare results from the European Commission, Community Bureau of Reference (BCR) sequential extraction procedure to the single-batch soil extraction methods. 


\subsection{MATERIALS AND METHODS}

\subsubsection{Soil samples}

Soil samples were collected from the Lehigh Gap Wildlife Refuge and Nature Center (LGWR) located at the Palmerton Zinc Superfund Site in Palmerton, Pennsylvania, U.S.A. The site is located adjacent to a historical zinc smelter (s) that had been in operation for nearly a century. Activity at these smelters have led to the defoliation of approximately $8.1 \mathrm{~km}^{2}(2000$ acres) in the vicinity (USEPA, 1987) mostly by aerial deposition of toxic elements cadmium, lead, and zinc. The site is mostly a boulder field that developed in the last Pleistocene glaciations (Pazzaglia et al., 2006). A USDA NRCS Soils Map (http://websoilsurvey.nrcs.usda.gov) with sampling locations is included in Figure 1.4. Samples were gathered from the top 0-30 cm depth, each of which supported little or no plant life.

Four soil samples were collected from different locations within the LGWR in the spring of 2009. One sample was collected from one of several amended monitoring plots that were created in 2003 that have received various fertilizers, mushroom compost, and warm season grasses. The remaining samples were collected throughout the site where no observable amending has been done, these samples for remainder will be called "unamended" (Table 2.1). Samples were brought into the laboratory, dried at room temperature, homogenized with a cement mixer to insure homogeneity, then refrigerated until analysis at $4{ }^{\circ} \mathrm{C}$.

\subsubsection{General soil characterization}

Soil pH was measured using the method established by Thomas (1996), where 1:1 soil slurry with deionized water and air-dried soil is measured in triplicate with a $\mathrm{pH}$ electrode (Beckman $\Phi 50 \mathrm{pH}$ meter). Organic matter content was measured by loss in ignition at $500{ }^{\circ} \mathrm{C}$. Percent moisture was determined by placing samples in a drying oven at $105+/-5{ }^{\circ} \mathrm{C}$ until soils were at a constant weight.

Cation exchange capacity (CEC) was determined using the compulsive exchange reaction method of Hendershot and Duquette (1986). Samples (2-g) were weighed and placed into $50 \mathrm{~mL}$ 
centrifuge tubes. A washing step with $20 \mathrm{~mL}$ of $100 \mathrm{mM} \mathrm{BaCl}_{2}$ followed by three independent washing steps with $20 \mathrm{~mL}$ of $25 \mathrm{mM} \mathrm{BaCl}{ }_{2}$ was executed with a $2 \mathrm{~h}$ shaking time on the shaker table at $150 \mathrm{rpm}$. A single overnight mixing-step was used with $20 \mathrm{~mL}$ of $25 \mathrm{mM} \mathrm{MgSO}$. The mixture was then centrifuged at $2500 \mathrm{x} g$ for $10 \mathrm{~min}$, followed by decanting and filtration of the supernatant with a $0.45-\mu \mathrm{m}$ Whatman syringe filter, and stored at $4{ }^{\circ} \mathrm{C}$ until analysis. The cation exchange capacity was calculated as the difference in total magnesium added minus the magnesium in the final solution multiplied by the milliequivalents of the magnesium containing extracting solutions.

\subsubsection{Fungal culture}

The mycorrhizal fungus Paxillus involutus (isolate ATCC 200175) was grown on a petri dish in agar containing modified Melin-Norkrans (MMN) media. The MMN media contained the following: $10 \mathrm{~g} / \mathrm{L}$ glucose, $2 \mathrm{mM}\left(\mathrm{NH}_{4}\right)_{2} \mathrm{HPO}_{4}, 4 \mathrm{mM} \mathrm{K \textrm {K } _ { 2 } \mathrm { PO } _ { 4 } , 0 . 5 \mathrm { mM } \mathrm { MgSO }} 4,1 \mathrm{mM} \mathrm{CaCl}$, $0.25 \mathrm{mM} \mathrm{NaCl}, 0.025 \mathrm{mM} \mathrm{KCl}, 0.0125 \mathrm{mM} \mathrm{H}_{3} \mathrm{BO}_{3}, 0.001 \mathrm{mM} \mathrm{MnSO}_{4}{ }^{*} \mathrm{H}_{2} \mathrm{O}, 0.001 \mathrm{mM}$ $\mathrm{ZnSO}_{4} * 7 \mathrm{H}_{2} \mathrm{O}, 0.00025 \mathrm{mM} \mathrm{CuSO}_{4} * 5 \mathrm{H}_{2} \mathrm{O}, 0.00025 \mathrm{mM} \mathrm{Na}_{2} \mathrm{MoO}_{4}, 0.00025 \mathrm{mM} \mathrm{CoCl}{ }_{2} * 6 \mathrm{H}_{2} \mathrm{O}$, $0.01 \mathrm{mM} \mathrm{Fe}$,Na-EDTA, $0.003 \mathrm{mM}$ thiamine $\mathrm{HCl}, 0.002 \mathrm{mM}$ pyridoxine $\mathrm{HCl}, 0.006 \mathrm{mM}$ ascorbic acid, and $0.04 \mathrm{mM}$ nicotinic acid. The $\mathrm{pH}$ was adjusted to 5 using $0.1 \mathrm{M} \mathrm{HCl}$ before autoclaving.

Following four weeks of incubation on solid MMN media, fungal colonies were transferred to a $250-\mathrm{mL}$ conical flask containing $\sim 50 \mathrm{~mL}$ of liquid MMN liquid media. Following four weeks of growth, cultures were filtered and culture media was then collected, following removal of fungal bodies. Liquid aliquots were vacuum filtered with a $0.45-\mu \mathrm{m}$ Whatman paper using a Buchner funnel and stored at $-20^{\circ} \mathrm{C}$ until use to minimize degradation.

\subsubsection{Determination of total metal concentrations in soil}

Determination of $\mathrm{Cd}$ and $\mathrm{Zn}$ was carried out after digestion with aqua regia of concentrated $\mathrm{HNO}_{3}$ and $\mathrm{HCl}$ by microwave-assisted digestion by Geoscience Laboratories (Ontario Canada) using the protocol established by 
(http://www.mndm.gov.on.ca/mines/ogs/labs/default_e.asp). Samples were leached overnight with room temperature aqua regia then digested for $1 \mathrm{hr}$ at $100^{\circ} \mathrm{C}$. These concentrations are referred to as Total-Cd and Total-Zn.

Pseudototal concentrations of $\mathrm{Cd}$ and $\mathrm{Zn}$ were also determined in accordance with Rauret et al. (1999). Soils were air-dried, passed through a 2-mm sieve, and placed in closed Teflon digestion vessels and subjected to microwave-assisted digestion in a MARSXpress system (CEM USA, Matthews, NC). Samples ( $3 \mathrm{~g}$ ) were digested with $28 \mathrm{~mL}$ of aqua regia (3:1 mixture of $37 \% \mathrm{HCl}$ and $70 \% \mathrm{HNO}_{3}$ ) at room temperature for $16 \mathrm{hr}$. Subsequently, the samples were transferred to the microwave digester at $130{ }^{\circ} \mathrm{C}$ at reflux conditions for $2 \mathrm{hr}$. The supernatant was filtered through a $0.45-\mu \mathrm{m}$ Whatman syringe filter and diluted to $100 \mathrm{~mL}$ with $0.5 \mathrm{M} \mathrm{HNO}_{3}$ and stored in polyethylene bottles at $4{ }^{\circ} \mathrm{C}$ until analysis.

\subsubsection{Sequential extraction}

Air-dried soils were subjected to the revised (four-step) sequential extraction protocol (the "BCR" method) developed by the Bureau of Common References (Rauret et al., 1999). Each soil sample was extracted in triplicate. The $\mathrm{pH}$ of the extractant was measured at the beginning and end of the agitation of the sample in each step, excluding step 4. All the extractants from each step were passed through a $0.45-\mu \mathrm{m}$ Whatman syringe filter and refrigerated at $4{ }^{\circ} \mathrm{C}$ until analysis.

Step 1 (water/acid soluble and exchangeable fraction): $1 \mathrm{~g}$ sample was treated with 40 $\mathrm{mL}$ of $0.11 \mathrm{M}$ acetic acid solution and was agitated on an orbital mixer at $30+/-10 \mathrm{rpm}$ for $16 \mathrm{hr}$ at room temperature. Separation of the supernatant was accomplished by centrifugation at $3000 \times \mathrm{g}$ for $20 \mathrm{~min}$. Following the removal of the supernatant, an additional washing step with $20 \mathrm{~mL}$ of deionized water for 15 min on the orbital mixer was used followed by centrifugation at $3000 \mathrm{x} g$ for $20 \mathrm{~min}$. The supernatant was then decanted and discarded. 
Step 2 (reducible fraction): The solid residue from the previous step was subjected to 40 $\mathrm{mL}$ of $0.5 \mathrm{M}$ hydroxylammonium chloride solution, adjusted to a $\mathrm{pH}$ of 1.5 with a fixed volume of $2 \mathrm{M} \mathrm{HNO}_{3}$. The sample was agitated on an orbital mixer at $30+/-10 \mathrm{rpm}$ for $16 \mathrm{hr}$ at room temperature. The supernatant and residue was separated as above. The residue was washed in the same fashion as above.

Step 3 (oxidizible fraction): To the residue from step 2, $10 \mathrm{~mL}$ of $8.8 \mathrm{M} \mathrm{H}_{2} \mathrm{O}_{2}$ solution was added. The slurry was digested for $1 \mathrm{hr}$ at room temperature and placed on a block digester for $1 \mathrm{hr}$ at $85+/-5{ }^{\circ} \mathrm{C}$, and the volume was reduced to less than $3 \mathrm{~mL}$. An additional $10 \mathrm{~mL}$ of $\mathrm{H}_{2} \mathrm{O}_{2}$ solution was added, the sample was digested for $1 \mathrm{hr}$ at $85+/-5$ ${ }^{\circ} \mathrm{C}$, and the volume was reduced to approximately $1 \mathrm{~mL}$. The extraction was accomplished by the addition of $50 \mathrm{~mL}$ of $1 \mathrm{M}$ ammonium acetate to the slurry, which was agitated on an orbital mixer at $30+/-10 \mathrm{rpm}$ for $16 \mathrm{hr}$ at room temperature. The supernatant and residue was separated similarly as the first step. The residue was washed in the same fashion as the first step.

Step 4 (residual fraction): The residue from the previous step was digested by aqua regia, however the volumes of $\mathrm{HCl}$ and $\mathrm{HNO}_{3}$ used have been reduced to $7 \mathrm{~mL}$ and 2.3 $\mathrm{mL}$, respectively. The mixture was digested similarly as the Pseudototal determination.

\subsubsection{Single Extraction experiments}

Leaching experiments were carried out to determine the bioavailability of $\mathrm{Cd}$ and $\mathrm{Zn}$ in soils collected from Palmerton. A variety of extractants were used to observe the effectiveness in extracting both analytes and to compare against fraction 1 and pseudototal of the sequential extraction protocol and are summarized in Table 2.2. Fungal media collected from MMN liquid cultures of $P$. involutus were also used to examine any similarity in extractability between the RBM and these solutions. Each sample was agitated on a windmill mixer, centrifuged as specified by each method, filtered with a $0.45-\mu \mathrm{m}$ Whatman filter and stored at $-20^{\circ} \mathrm{C}$ until analysis. Extra caution was used with organic-based extractants where each sample container was covered with aluminum foil to minimize photodegradation. 


\subsubsection{Analyses and quality control}

All glassware and plasticware were washed with $0.2 \mathrm{M} \mathrm{HCl}$ and allowed to soak overnight and rinsed with deionized water. All reagents were of analytical grade. Concentrations of $\mathrm{Cd}, \mathrm{Zn}$, and $\mathrm{Mg}$ were determined using a Varian 220FS atomic absorption spectrometer (Varian Inc., Mulgrave, Vic., Australia). Blanks were included in microwave digestions and sequential extractions, and quality of analysis was analyzed by spike and recovery. BCR CRM 701 was analyzed by BCR procedure, to ensure proper extraction using the BCR revised method.

The recoveries of analytes $(\mathrm{Cd}$ and $\mathrm{Zn})$ using spike and recovery in extracts and digests were $100 \pm 20 \%$. Recovery of analytes (Cd and $\mathrm{Zn}$ ) from BCR CRM 701 from each batch sequential extraction was $100 \%$. The recovery of analytes ( $\mathrm{Cd}$ and $\mathrm{Zn}$ ) from the BCR extraction procedure, where combining the individual steps and comparing amounts detected to the results of a separate aqua regia digest, ranged from $73 \%$ to $144 \%$.

\subsection{RESULTS}

\subsubsection{Soil characterization}

All soils collected from the LGWR had mean concentrations of $\mathrm{Cd}$ and $\mathrm{Zn}$ that exceed the guidelines set by the USEPA (USEPA, 2001) (Table 2.3). Soil pH of the four soils were slightly acidic and typical of soils found within Blue Mountain province (USDA, 2011), with exception of the one sample that had a higher $\mathrm{pH}$ likely in response due to amendment. The two samples containing the highest metal concentration, both PLM-B1 and PLM-B3, had both higher TOC and CEC values compared to the two samples containing lower metal concentration.

\subsubsection{Sequential extraction}

The revised BCR sequential extraction data illustrating both $\mathrm{Cd}$ and $\mathrm{Zn}$ extractability for all four soils by fraction and extraction yield are on Figure 2.1. Actual values with standard deviation and means with statistical analysis using Tukey-Kramer Method for each soil sample 
are located on Table 2.4. Overall trends using extraction yields to evaluate both $\mathrm{Cd}$ and $\mathrm{Zn}$ availability in samples are as follows: $\mathrm{Cd}$ reducibles>exchangeables>oxidizables>residuals; $\mathrm{Zn}$ exchangeables $>$ residuals $>$ reducibles $>$ oxidizables. Pseudototals determined by summing all fractions of the sequential extraction show trends of the following: Cd PLM-B3 $\geq$ PLM-B1>PLM-

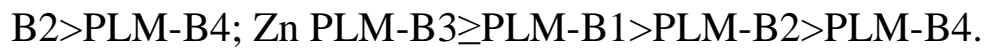

In the first step of the extraction scheme, $\mathrm{pH}$ values of the acetic acid solution ranged from 3.40 to 3.75 with a $\Delta \mathrm{pH}$ (Final $\mathrm{pH}-$ Beginning $\mathrm{pH}$ ) ranging from 0.46 to 0.69 where the $\mathrm{pH}$ rose from original $\mathrm{pH}$ (the $\mathrm{pH}$ value of the $0.11 \mathrm{M}$ acetic acid solution was 2.85). The range in extracted $\mathrm{Zn}$ from fraction 1 is 2887 to $5396 \mathrm{mg} / \mathrm{kg}$ dry weight. In soil sample PLM-B3, 5396 $\mathrm{mg} / \mathrm{kg}$ equates to $51 \%$ of the total $\mathrm{Zn}$ within this sample, where in soil sample PLM-B4 nearly $62 \%$ of the total $\mathrm{Zn}$ was removed in the first step of this extraction protocol. The range in extracted Cd from fraction 1 is 14 to $89 \mathrm{mg} / \mathrm{kg}$ dry weight. The range of percent Cd extracted is from 20 to $36 \%$ of the total $\mathrm{Cd}$ within these samples. In all soil samples $\mathrm{Zn}$ is mostly bound to the exchangeable and weak-acid soluble phase. In soil sample PLM-B2, Cd is mostly operationally bound to fraction 1 .

The second step of the extraction scheme, $\mathrm{pH}$ values of the extracting solution ranged from 1.62 to 1.91 while the $\Delta \mathrm{pH}$ ranged from +0.06 to +0.24 (the $\mathrm{pH}$ value of the $0.5 \mathrm{M}$ hydroxylammonium chloride solution was 1.56). The range in extracted $\mathrm{Zn}$ from fraction 2 is 203 to $3263 \mathrm{mg} / \mathrm{kg}$ dry weight. This relates to a 4 to $25 \% \mathrm{Zn}$ extracted from the total available $\mathrm{Zn}$ in these samples. The range of extracted $\mathrm{Cd}$ from fraction 2 is 6 to $112 \mathrm{mg} / \mathrm{kg}$ dry weight. The range of percent $\mathrm{Cd}$ extracted is from 9 to $45 \%$ of the total $\mathrm{Cd}$ available. In both soil samples PLM-B1 and B3 Cd is mostly bound to reducible phase.

The third step of the $\mathrm{BCR}$ extraction scheme the $\mathrm{pH}$ of the extracting solutions range from 2.16 to 2.26 while the $\Delta \mathrm{pH}$ ranged from +0.01 to +0.03 (the original $\mathrm{pH}$ value of the $1 \mathrm{M}$ ammonium acetate solution was 2.09). The range in extracted $\mathrm{Zn}$ from this fraction is 355 to $1156 \mathrm{mg} / \mathrm{kg}$ dry weight. This relates to a 4 to $9 \% \mathrm{Zn}$ extracted from the total available $\mathrm{Zn}$ in these samples. The range of extracted $\mathrm{Cd}$ from fraction 3 is 25 to $38 \mathrm{mg} / \mathrm{kg}$ dry weight. The 
range of percent $\mathrm{Cd}$ extracted is from 9 to $46 \%$ of the total Cd available. In soil sample PLM-B4, the oxidizable fraction was the greatest sequester of $\mathrm{Cd}$ in all of the fractions for this sample.

The overall effectiveness of the sequential extraction protocol can be scrutinized by comparing the sum of all four fractions versus the pseudototal of the soils of interest. The percent Zn extracted for soils PLM-B1 through PLM-B4 are 83, 90, 99, and 105\% respectively. The percent Cd extracted for soils PLM-B1 through PLM-B4 are 83, 95, 99 and 80\% respectively.

\subsubsection{Batch leaching extractions}

Concentration averages for $\mathrm{Cd}$ and $\mathrm{Zn}$ extracted by the single batch extractions for all samples are illustrated in Figure 2.2a, respectively. In respect to common extractants used for determining plant availability, the general trend for extraction efficiency for Cd is EDTA $\cong$ DTPA $>$ Mehlich-III $>\mathrm{RBM}>>\mathrm{H}_{2} \mathrm{O}$. As for efficacy of removal of $\mathrm{Cd}$ from soils utilizing $P$. involutus (Pax) exudates, this solution only slightly underperformed compared to RBM and Mehlich-III combined. Pax solution effectively removed $64 \%$ and $27 \%$ more than the above mentioned extractants, respectively. This may reflect $\mathrm{pH}$ and buffering capacity of solutions preand post-extraction, where Pax and Mehlich-III have similar pH pre-extraction, where RBM is $\sim 0.75$ units higher. Whereas, post-extraction $\Delta \mathrm{pH}$ for these three extractants are Pax>MehlichIII $>$ RBM, suggesting RBM is a more buffered solution than the others. Fraction 1 of the modified BCR sequential extraction method grossly overestimates Cd, even compared to EDTA and DTPA by a factor of 3. Average percentages of $\mathrm{Cd}$ extracted with the extraction methods used compared to total concentration are presented in Figure 2.2b. Statistically, as for percent Cd extracted compared to the pseudototal, Pax and Mehlich-III show no statistical difference, where the RBM shares statistical similarity to MMN.

Zinc extractability in soils by common extractants had a general trend for extractability for $\mathrm{Zn}$ are DTPA $\geq$ EDTA $>$ Mehlich-III $>\mathrm{RBM}>>\mathrm{H}_{2} \mathrm{O}$ as illustrated in Figure 2.2c. EDTA and DTPA extracted nearly twice as much in these samples than any other extractant used in this study, with no statistical difference between the extractants. The Pax extraction yielded statistically similar concentrations to Mehlich-III and the RBM. The statistically similarity of 
Pax with RBM and Mehlich-III may foreshadow that fungal exudate solution as an extractant may be a good estimate of $\mathrm{Zn}$ availability, whereas, compared to EDTA and DTPA, it underestimates $\mathrm{Zn}$ concentration by a factor 1.5. As similar to $\mathrm{Cd}$, Fraction 1 overestimates $\mathrm{Zn}$ extractability as an estimate of bioavailability compared to the other extractants used, minimally by a factor greater than 3. Average percentages of $\mathrm{Zn}$ extracted with the extraction methods used compared to total concentration are presented in Figure 2.2d. As for percent Zn extracted compared to the pseudototal, Pax shows no statistical difference between Mehlich-III, RBM and MMN.

\subsection{DISCUSSION}

Soils collected from smelter sites generally have a signature of extremely high contents of heavy metals (Grčman et al., 2001; Ettler et al., 2004). At the LGWR and within Palmerton vicinity, both $\mathrm{Cd}$ and $\mathrm{Zn}$ persist at levels that have led to defoliation of the Borough of Palmerton and the surrounding areas (USEPA, 2002). Elliott and Shastri (1999) reported concentrations of $\mathrm{Cd}$ and $\mathrm{Zn}$ at Palmerton to be 280 and $2700 \mathrm{mg} / \mathrm{kg}$, respectively. Adriano (2001) shares that during the 100 years of operation, smelting operations by New Jersey Zinc Company in Palmerton, PA emitted an estimated total of 260,000 tonnes of $\mathrm{Zn}$ and 330 tonnes of Cd, relating to approximately 50 to $100 \mathrm{~kg} \mathrm{Zn/1} \mathrm{kg} \mathrm{Cd} \mathrm{emitted.} \mathrm{Due} \mathrm{to} \mathrm{the} \mathrm{size} \mathrm{and} \mathrm{heterogeneity} \mathrm{of} \mathrm{the} \mathrm{site,}$ these gross indices may greatly underestimate the extent of contamination that may be affected by the sampling size. Using single extraction methods to determine extractability of metals has been a convention used to simply and efficiently measure metals in soil samples. Conversely, the use of sequential extraction is a powerful indirect approach to determine how metals operationally act in soils of interest (Bacon and Davidson, 2009). When used together, these methods may give a more representative picture of how metals are interacting in different partitions and can be potentially used as a check and balance against the effectiveness of single extraction.

In the revised BCR sequential extraction protocol the pseudototal extraction, an aqua regia extraction, gives a preliminary understanding of the total concentration of the soils that are being explored. This can be used to compare against metal(s) total data received from an outside 
source or other laboratories studying the same soils to ensure quality of extraction. The pseudototal can also be used to check against the efficacy of the four-step extraction process incorporated in the sequential extraction, where all four steps are summed than compared to the pseudototal. The efficiency of our extraction compared against an outside laboratory (Geoscience Laboratories, Ontario, Canada) for $\mathrm{Cd}$ and $\mathrm{Zn}$ in study for soils PLM-B1 through B4 are as followed, respectively: $109 \%$ and $95 \%, 106 \%$ and $101 \%, 95 \%$ and $96 \%, 173 \%$ and $97 \%$. The outlier, PLM-B4 for Cd, may be result of operator error or some other erroneous account, where the sum of the four steps for this soil compared to the pseudototal results in an extraction efficiency of $80 \%$.

In general, all methods used for single extractions for $\mathrm{Zn}$ when compared to the first-step in the revised BCR sequential extraction protocol greatly underestimate "exchangeable" or "acid-soluble" content of these soils. Extracting solutions EDTA and DTPA remove approximately from 19 to $49 \%$ of $\mathrm{Zn}$ of what is considered exchangeable in the sequential extraction protocol. Whereas for $\mathrm{Cd}$, these acids only removed approximately 28 to $57 \%$ of $\mathrm{Cd}$ in the four soils studied where compared to the first step of the sequential extraction protocol. This may be a factor of concentrations of the extractants used, where the acetic acid used in step 1 is a factor of 22 greater in concentration than the polyaminecarboxylic acids used. Due to the nonselectivity of $\mathrm{H}^{+}$ions in these solutions, the lower concentrated acids may see complete consumption of $\mathrm{H}^{+}$ions by reactions with calcareous materials, oxides, and may invoke exchange reactions with mono- and divalent ions (Bermond, 2001). Other possibilities are the differences in solution to soil ratio and leaching time for all extractants used compared to Step 1. The solution to soil ratio for all extraction with exception to water was 10, where in Steps 1 and 2 the ratio is 40 . In the leaching process, due to solubility and distribution equilibrium, solution to soil ratio may affect the constituent release of ions and leaching parameters such as: $\mathrm{pH}$, redox, dissolved organic carbon content, speciation, and reaction kinetics (Schuwirth and Hofmann, 2006).

Comparing sequential extraction data from other studies have shown to be difficult due to uniqueness of compared site, source of pollution, and variety materials and methods used. The classic Tessier et al. (1979) five-step sequential extraction method was the first method 
developed to interpret fractionation in fluvial bottom sediments. Since the development of this method, the sequential extraction method has deviated into several other methods that have different procedures, number of extraction steps, reagents and optimized conditions, having led to increased difficulties in interpreting and comparing data from different sources (Bacon and Davidson, 2009). For the ease of comparing fractionation patterns from this study versus methods used in many others, combining the first two steps (Exchangeable/Bound to Carbonates) of Tessier et al. (1979) and the first three steps (Water Soluble/Exchangeable/Carbonate Bound) of Ma and Rao (1997) will suffice the comparison of Step 1 of the Revised BCR sequential extraction method (Rauret et al., 1999). In Elliott and Shastri (1999) study of a Palmerton soil found that approximately $40 \%$ of $\mathrm{Cd}$ and $29 \%$ of $\mathrm{Zn}$ is associated with the first two steps of Tessier method. As for Ma and Rao (1997) study of multiple soil types and sources, samples collected from smelting sites that had a concentration of $\mathrm{Zn}>1000 \mathrm{mg} / \mathrm{kg}$ and $\mathrm{Cd}>50 \mathrm{mg} / \mathrm{kg}$, that approximately $30 \%$ of $\mathrm{Cd}$ and $15 \%$ of $\mathrm{Zn}$ was associated with the first three steps of the sequential extraction scheme used. In this study of four soils from Palmerton, approximately $35 \%$ of $\mathrm{Cd}$ total and $48 \%$ of $\mathrm{Zn}$ total was determined to be associated with Step 1 of the revised BCR method. The concentrations found in this study slightly differentiate then the reported values of Elliott and Shastri (1999), however due to both physical and chemical changes weighted by time, these values correspond to rehabilitating soils that have seen fractionation change due to natural and human induced activities. These compounding variables have led to the gradual translation of fractionation of $\mathrm{Cd}$ and $\mathrm{Zn}$ in all samples, where both these elements have become more available over time, from residual to non-residual fractions. Interestingly, Cd remains strongly associated with Fe-Mn oxide and organically bound fractions, where $\mathrm{Zn}$ has maintained the highest availability in exchangeable and residual forms.

The use of fungal media as collected in the fashion of this study enabled a comparison between traditional extraction methods (i.e., EDTA, DTPA, etc.) and more modern methods for predicting bioavailability using a "cocktail" of organic acids approach, such as the Rhizosphere Based Method. Feng et al. (2007) argue that the RBM may be more representative of rhizosphere conditions due to the LMWOAs used that are exudates of plants, fungi and bacteria that may mimic more real world conditions found within the rhizosphere. In simple batch extractions, the single medium used had been fungi grown on liquid media to simulate these similar conditions 
referred to by the RBM chemically, however by a living organism. In determining extractability of $\mathrm{Cd}$ in all four samples, the RBM and Mehlich-III were statistically significantly $(\mathrm{p}<0.05)$ different to the $P$. involutus medium. The extractability of $\mathrm{Zn}$ by $P$. involutus medium proved that the Mehlich-III and RBM extractions were statistically similar. This may suggest that in using the RBM as a qualifier for predicting bioavailability of $\mathrm{Cd}$ and $\mathrm{Zn}$ as a viable tool smelter contaminated soils, however other methods (i.e. Mehlich-III) should be used to test the efficacy of this sensitive extraction. Additionally, a greater understanding of how fungal inoculation in remediation projects that aid host species establish in these metal laden environments may lead to subsequent high initial release of heavy metals into the environment by leaching action.

\subsection{CONCLUSION}

The influence of inoculants on heavy metal mobility has profound effects on biota in regards of increased potential for uptake and release into the surrounding environment. Alongside with synthetic organic acids used to increase uptake in plants for remedial purposes, much care must be taken to insure that these applications are effective yet safe. Several single extraction methods were used to evaluate the extractability of $\mathrm{Cd}$ and $\mathrm{Zn}$ from four Palmerton soils against a liquid fungal medium derived from Paxillus involutus liquid culture. We found that the liquid culture extracted $\mathrm{Cd}$ and $\mathrm{Zn}$ similarly as commonly-accepted extractants used to determine bioavailability. There is still considerable work that needs to be done in characterizing exudates produced in mycorrhizal fungi when exposed to elevated metal levels. These exudates have the ability to sequester and release heavy metals within the rhizosphere, so much consideration must be taken when using fungal inoculants in conjunction with symbiotic plant species.

The Rhizosphere-Based Method proved to be a good qualifier as for comparing to the single fungal medium used for determining availability of Zn, where Mehlich-III extraction had greater efficacy for determining both $\mathrm{Cd}$ and $\mathrm{Zn}$ availability. These tests can act in preliminary assessments in determining the potential for release of heavy metals associated with amendment additions, such as mushroom compost, when vegetation is being reintroduced to contaminated sites. The use of polyaminecarboxylic acids such as EDTA and DTPA may over estimate labile 
heavy metal concentrations and yet may underestimate what is generally considered by many the "exchangeables" or "water- and acid-soluble" fractions of the revised BCR sequential extraction method.

\subsection{REFERENCES}

Awad F, Römheld V. Mobilization of heavy metals from contaminated calcareous soils by plant born, microbial and synthetic chelators and their uptake in wheat plants. Journal of Plant Nutrition 2000; 23: 1847-1855.

Bacon JR, Davidson CM. Is there a future with sequential chemical extraction? Analyst 2008; 133: 25-46.

Bermond A. Limits of sequential extraction procedures re-examined with emphasis on the role of $\mathrm{H}^{+}$ion reactivity. Analytica Chimica Acta 2001; 445: 79-88.

Cornejo P, Meiera S, Borie G, Rillig MC, Borie F. Glomalin-related soil protein in a Mediterranean ecosystem affected by a copper smelter and its contribution to $\mathrm{Cu}$ and $\mathrm{Zn}$ sequestration. Science of the Total Environment 2008; 406: 154-160.

Cunningham SD, Ow DW. Promises and prospects of phytoremediation. Plant Physiology 1996; 110: 715-719.

Degryse F, Verma VK, Smolders E. Mobilization of $\mathrm{Cu}$ and $\mathrm{Zn}$ by root exudates of dicotyledonous plants in resin-buffered solutions in soil. Plant Soil 2008; 306: 96-84.

Elliott HA, Shastri NL. Extractive decontamination of metal polluted soils using oxalate. Water, Air, and Soil Pollution 1999; 110: 335-346.

Ettler V, Komárková M, Jehlička J, Coufal P, Hradil D, Machovič V, Delorme F. Leaching of lead metallurgic slag in citric solutions - Implications for disposal and weathering in soil environments. Chemosphere 2004; 57: 567-577.

Evangelou MWH, Ebel M, Schaeffer A. Chelate assisted phytoextraction of heavy metals from soil. Effect, mechanism, toxicity, and fate of chelating agents. Chemosphere 2007; 68: 989-1003.

Feng M, Shan X, Zhang S, Wen B. A comparison of the rhizosphere-based method with DTPA, EDTA, $\mathrm{CaCl}_{2}$, and $\mathrm{NaNO}_{3}$ extraction methods for prediction of bioavailability of metals in soil to barley. Environmental Pollution 2005; 137: 231-240.

Gallagher FJ, Pechmann L, Bogden JD, Grabosky J, Weis P. Soil metal concentrations and vegetative assemblage structure in an urban brownfield. Environmental Pollution 2008; 153:351-361.

Giller KE, Witter E, McGrath SP. Toxicity of heavy metals to microorganisms and microbial processes in agricultural soils: a review. Soil Biology and Biochemistry 1998; 30: 13891414.

Grčman H, Velikonja-Bolta Š, Vodnik D, Kos B, Leštan D. EDTA enhanced heavy metal phytoextraction: metal accumulation, leaching and toxicity. Plant Soil 2001; 235: 105114.

Heil DM, Samani Z, Hanson AT, Rudd B. Remediation of lead contaminated soil by EDTA. I. Batch and column studies. Water, Air, and Soil Pollution 1999; 113: 77-95. 
Hendershot WH, Duquette M. A simple barium chloride method for determining cation exchange capacity and exchangeable cations. Soil Science Society of America Journal 1986; 50: 605-608.

Leštan D, Luo CL, Li XD. The use of chelating agents in the remediation of metal-contaminated soils: a review. Environmental Pollution 2008; 153: 3-13.

Li Z, Shuman LM. Extractability of zinc, cadmium, and nickel in soils amended with EDTA. Soil Science 1996; 161: 226-232.

Lindsay WL, Norvell WA. Development of a DTPA test for zinc, iron, manganese, and copper. Soil Science Society of America Journal 1979; 42: 421-428.

Ma LQ, Rao GN. Chemical fractionation of Cadmium, Nickel, and Zinc in contaminated soils. Journal of Environmental Quality 1997; 26: 259-264.

McGrath SP, Zhao FJ, Lombi E. Plant and rhizosphere process involved in phytoremediation of metal-comtaminated soils. Plant Soil 2001; 232: 207-214.

Meers E, Du Laing G, Unamuno V, Ruttens A, Vangronsveld J, Tack FMG, Verloo MG. Comparison of cadmium extractability from soils by commonly used single extraction protocols. Geoderma 2007; 141: 247-259.

Mrnka L, Kuchár M, Cieslarová Z, Matějka P, Száková J, Tlustoš P, Vosátka M. Effects of endoand ectomycorrhizal fungi on physiological parameters ad heavy metal accumulation of two species from the family Salicaceae. Water, Air, and Soil Pollution 2012; 223: 399410.

Norvell WA. Comparison of chelating agents as extractants for metals in diverse soil materials. Soil Science Society of America Journal 1984; 48: 1285-1292.

Panda S, Matsumoto H. Molecular physiology of aluminum toxicity and tolerance in plants. Botanical Review 2007; 73: 326-347.

Pazzaglia FJ, Braun DD, Pavich M, Bierman P, Potter N, Merritts D, Walter R, Germanoski D. Rivers, glaciers, landscape evolution, and active tectonics of the central Appalachians, Pennsylvania and Maryland. In: Pazzaglia FJ, editor. Excursions in Geology and History: Field Trips in the Middle Atlantic States: Geological Society of America Field Guide 8. Denver: Geological Society of America; 2006. p. 169-197.

Pierzynski GM, Schwab AP. Bioavailability of zinc, cadmium, and lead in a metal contaminated alluvial soil. Journal of Environmental Quality 1993; 22: 247-254.

Quartacci MF, Irtelli B, Gonnelli C, Gabbrielli R, Navari-Izzo F. Naturally-assisted metal phytoextraction by Brassica carinata: Role of root exudates. Environmental Pollution 2009; 157: 2697-2703.

Rauret G, López-Sánchez JF, Sahuquillo A, Rubio R, Davidson C, Ure A, Quevaviller Ph. Improvement of the BCR three step sequential extraction procedure prior to the certification of new sediment and soil reference materials. Journal of Environmental Monitoring 1999; 1: 57-61.

Robinson BH, Mills TM, Petit D, Fung LE, Green SR, Clothier BE. Natural and induced cadmium-accumulation in poplar and willow: Implications for phytoremediation. Plant and Soil 2000; 227: 301-306.

Schuwirth N, Hoffman T. Comparability of and alternatives to leaching tests for the assessment of the emissions of inorganic soil contamination. Journal of Soils and Sediments 2006; 6: 102-112. 
Seguel A, Cumming JR, Klugh-Stewart K, Cornejo P, Borie F. The role of arbuscular mycorrhizas in decreasing aluminum phytotoxicity in acidic soils: a review. Mycorrhiza 2013; 23: 167-183.

Shan X, Wang Z, Wang W, Zhang S, Wen B. Labile rhizosphere soil solution fraction for prediction of bioavailability of heavy metals and rare earth elements to plants. Analytical and Bioanalytical Chemistry 2003; 375: 400-407.

Soriano-Disla JM, Navarro-Pederño J, Gómez I. Contribution of a sewage sludge application to the short-term carbon sequestration across a wide range of agricultural soils. Environmental Science 2010; 61: 1613-16-19.

Soriano-Disla JM, Gómez I, Navarro-Pederño J. Use of a Rhizosphere-Based Method for the Assessment of Heavy-Metal Bioavailability in Soils Amended with Polluted Sewage Sludge. Communications in Soil Science and Plant Analysis 2013; 44: 1599-1609.

Sun B, Zhao FJ, Lombi E, McGrath SP. Leaching heavy metals from contaminated soils using EDTA. Environmental Pollution 2001; 113: 111-120.

Tessier A, Campbell PGC, Bisson M. Sequential Extraction Procedure for the Speciation of Particulate Trace Metals. Analytical Chemistry 1979; 51: 844-851.

Thomas GW. Soil pH and soil acidity. In: Bigham JM, editor. Methods of Soil Analysis: Part 3 Chemical Methods, Soil Science Society of America Series No. 5. Madison: Soil Science Society of America and American Society of Agronomy; 1996. p. 475-490.

USDA. Custom Soil Resource Report for Carbon County, Pennsylvania, and Lehigh County, Pennsylvania. Washington D.C: NRCS; 2011.

USEPA. Palmerton Zinc Superfund Site Blue Mountain Project, Summary of RI/FS Results. Philadelphia: USEPA Region III; 1987.

USEPA. Final Draft Palmerton Zinc Site Ecological Risk Assessment. Philadelphia: USEPA Region III; 2001.

USEPA. Second Five-Year Review Report. Palmerton Zinc Pile Superfund Site. Philadelphia: USEPA Region III; 2002.

van Hullebusch E, Lens PNL, Tabak HH. Advances in Bioremediation of Soils and Sediments Polluted with Metals and Radionuclides. 3. Overview of the Influence of Chemical Speciation and bioavailability on Contaminate Immobilization/Mobilization BioProcesses. Reviews in Environmental Science \& Biotechnology 2005; 4: 185-212. 
Table 2.1 Plot descriptions of site and sample locations at LGWR, Palmerton, Pennsylvania, U.S.A.

\begin{tabular}{|c|c|c|c|c|c|}
\hline Site/Sample & \multicolumn{2}{|c|}{ Longitude/Latitude (WGS84) } & Elevation (m) & $\begin{array}{c}\text { Management } \\
\text { History }\end{array}$ & $\begin{array}{l}\text { Vegetative } \\
\text { Cover }\end{array}$ \\
\hline PLM-B1 & -75.6212 & 40.7904 & 248 & $\begin{array}{c}\text { Aerial } \\
\text { Fertilizer/Seed } \\
\text { Application }\end{array}$ & $60 \%$ Grasses \\
\hline PLM-B2 & -75.6217 & 40.7912 & 218 & $\begin{array}{c}\text { Aerial } \\
\text { Fertilizer/Seed } \\
\text { Application }\end{array}$ & 95\% Grasses \\
\hline PLM-B3 & -75.6223 & 40.7912 & 218 & $\begin{array}{c}\text { Aerial } \\
\text { Fertilizer/Seed } \\
\text { Application }\end{array}$ & $\begin{array}{c}\text { Existing Tree } \\
\text { Grove (Red } \\
\text { Oak, Sassafras) }\end{array}$ \\
\hline PLM-B4 & -75.6225 & 40.7432 & 166 & $\begin{array}{c}\text { Amended with } \\
\text { Turkey Manure, } \\
\text { Compost, Lime, } \\
\text { warm season } \\
\text { grasses }\end{array}$ & $\begin{array}{c}80 \% \text { Grasses, } \\
\text { revegetated by } \\
\text { Betula spp. }\end{array}$ \\
\hline
\end{tabular}

Table 2.2 Summary of Single Extractions used in Batch Leaching

\begin{tabular}{ccccc}
\hline Extractants & Leaching Time & Concentration & $\begin{array}{c}{ }^{1} \text { SSR } \\
\mathrm{mL} / \mathrm{g}\end{array}$ & Reference \\
\hline EDTA & $1 \mathrm{hr}$ & $0.005 \mathrm{M}$ & 10 & Matús et al. (2005) \\
DTPA & $1 \mathrm{hr}$ & $0.005 \mathrm{M}$ & 10 & Matús et al. (2005) \\
$\begin{array}{c}\text { Rhizosphere Based } \\
\text { Method } \\
\text { Mehlich-III }\end{array}$ & $16 \mathrm{hrs}$ & - & 10 & Feng et al. (2005) \\
$\mathrm{H}_{2} \mathrm{O}$ & $5 \mathrm{~min}$ & - & 10 & Mehlich (1984) \\
\hline $\begin{array}{c}\text { Fungal Media } \\
\text { Modified Melin }\end{array}$ & $24 \mathrm{hrs}$ & - & 5 & Kubová et al. (2005) \\
\hline $\begin{array}{c}\text { Norkins (MMN) } \\
\text { Pax }\end{array}$ & $16 \mathrm{hrs}$ & - & 10 & - \\
\hline
\end{tabular}

${ }^{1}$ SSR - Soil to Solution Ratio 
Table 2.3 Soil Characteristics of the LGWR, Palmerton, Pennsylvania, U.S.A.

\begin{tabular}{|c|c|c|c|c|c|c|c|c|c|c|c|c|}
\hline Sample & $\begin{array}{c}\text { Soil } \\
\mathrm{pH}_{\mathrm{H} 2 \mathrm{O}}\end{array}$ & $\begin{array}{l}\text { TOC } \\
(\%)\end{array}$ & $\begin{array}{c}\mathrm{CEC} \\
\underset{(\mathrm{meq} / 100}{\mathrm{g})}\end{array}$ & $\begin{array}{c}\mathrm{Cd}_{\text {Total }} \\
(\mathrm{mg} / \mathrm{kg})\end{array}$ & $\begin{array}{c}\mathrm{Zn}_{\text {Total }} \\
(\mathrm{mg} / \mathrm{kg})\end{array}$ & $\begin{array}{c}\mathrm{Pb}_{\text {Total }} \\
(\mathrm{mg} / \mathrm{kg})\end{array}$ & $\begin{array}{c}\mathrm{Al}_{\text {Total }} \\
(\mathrm{mg} / \mathrm{kg})\end{array}$ & $\begin{array}{c}\mathrm{Fe}_{\text {Total }} \\
(\mathrm{mg} / \mathrm{kg})\end{array}$ & $\begin{array}{l}\mathrm{Mn}_{\text {Total }} \\
(\mathrm{mg} / \mathrm{kg})\end{array}$ & $\begin{array}{c}\mathrm{Ca}_{\text {Total }} \\
(\mathrm{mg} / \mathrm{kg})\end{array}$ & $\begin{array}{c}\mathrm{K}_{\text {Total }} \\
(\mathrm{mg} / \mathrm{kg})\end{array}$ & $\begin{array}{c}\mathrm{Mg}_{\text {Total }} \\
(\mathrm{mg} / \mathrm{kg})\end{array}$ \\
\hline $\begin{array}{c}\text { PLM-B1 } \\
\text { (Non- } \\
\text { Amended) }{ }^{1}\end{array}$ & 5.42 & 18.3 & 28.6 & 254 & 13503 & 1735 & 10802 & 33188 & 8305 & 4342 & 675 & 1134 \\
\hline $\begin{array}{c}\text { PLM-B2 } \\
\text { (Non- } \\
\text { Amended) }{ }^{1}\end{array}$ & 5.60 & 6.8 & 13.7 & 138 & 7909 & 795 & 11781 & 32842 & 4630 & 2789 & 901 & 1133 \\
\hline $\begin{array}{c}\text { PLM-B3 } \\
\text { (Non- } \\
\text { Amended) }{ }^{1}\end{array}$ & 5.44 & 21.5 & 29.6 & 262 & 11170 & 1947 & 9934 & 33104 & 9794 & 3608 & 625 & 1024 \\
\hline $\begin{array}{l}\text { PLM-B4 } \\
\text { (Amended) }\end{array}$ & 6.36 & 2.8 & 8.7 & 40 & 4783 & 197 & 16381 & 33308 & 2834 & 1674 & 917 & 1248 \\
\hline Typical $^{2}$ & - & - & - & $0.01-2$ & $1-900$ & - & - & - & - & - & - & - \\
\hline USEPA $^{3}$ & - & - & - & 1.2 & 150 & - & - & - & - & - & - & - \\
\hline $\mathrm{PA} \mathrm{DCNR}^{4}$ & - & - & - & $\begin{array}{l}293- \\
1750\end{array}$ & $\begin{array}{l}11800- \\
135000\end{array}$ & - & - & - & - & - & - & - \\
\hline
\end{tabular}

All element totals of field samples were determined by Geoscience Laboratories, Ontario, Canada.

Non-Amended - collected outside "test-plots" from a non-amended location; Amended - collected within "Test-Plots" and have received a regime of amendments (In methods).

${ }^{2}$ Typical soil concentrations found within the environment in non-polluted conditions are from Trace Elements in Terrestrial Environments: Biogeochemistry, Bioavailability, and Risk of Metals, $2^{\text {nd }}$ Edition, D. Adriano, Springer, New York, 2001.

${ }^{3 / 4}$ Both USEPA and PA DCNR soil concentrations are from Region III Ecological Guidelines and the Palmerton Zinc Superfund Site, Palmerton, PA, respectively.

These values are found in Preassessment Screen Determination for the Palmerton Zinc Pile Superfund Site, Pennsylvania DCNR, Harrisburg, 2003. 
Table 2.4 Revised BCR Sequential Extraction Results for Palmerton Soils

\begin{tabular}{|c|c|c|c|c|c|c|c|c|c|c|c|c|}
\hline \multirow{2}{*}{ Sample } & \multirow{2}{*}{$\begin{array}{c}\mathrm{Cd}_{\text {Pseudot }} \\
\text { otal } \\
(\mathrm{mg} / \mathrm{kg})\end{array}$} & \multirow{2}{*}{$\begin{array}{l}\mathrm{Zn}_{\text {Pseudot }} \\
\text { otal } \\
(\mathrm{mg} / \mathrm{kg})\end{array}$} & \multicolumn{2}{|c|}{ Fraction 1} & \multicolumn{2}{|c|}{ Fraction 2} & \multicolumn{2}{|c|}{ Fraction 3} & \multicolumn{2}{|c|}{ Fraction 4} & \multicolumn{2}{|c|}{ Sum of Fractions } \\
\hline & & & $\begin{array}{c}\mathrm{Cd} \\
(\mathrm{mg} / \mathrm{kg})\end{array}$ & $\begin{array}{c}\mathrm{Zn} \\
(\mathrm{mg} / \mathrm{kg})\end{array}$ & $\begin{array}{c}\mathrm{Cd} \\
(\mathrm{mg} / \mathrm{kg})\end{array}$ & $\begin{array}{c}\mathrm{Zn} \\
(\mathrm{mg} / \mathrm{kg})\end{array}$ & $\begin{array}{c}\mathrm{Cd} \\
(\mathrm{mg} / \mathrm{kg})\end{array}$ & $\begin{array}{c}\mathrm{Zn} \\
(\mathrm{mg} / \mathrm{kg})\end{array}$ & $\begin{array}{c}\mathrm{Cd} \\
(\mathrm{mg} / \mathrm{kg})\end{array}$ & $\begin{array}{c}\mathrm{Zn} \\
(\mathrm{mg} / \mathrm{kg})\end{array}$ & $\begin{array}{c}\mathrm{Cd} \\
(\mathrm{mg} / \mathrm{kg})\end{array}$ & $\begin{array}{c}\mathrm{Zn} \\
(\mathrm{mg} / \mathrm{kg})\end{array}$ \\
\hline $\begin{array}{l}\text { PLM-B1 } \\
\text { (Non- } \\
\text { Amended) }\end{array}$ & $\begin{array}{c}278 \\
\pm 23 \mathrm{a}\end{array}$ & $\begin{array}{c}12900 \\
\pm 2630 \mathrm{a}\end{array}$ & $\begin{array}{c}88 \\
\pm 3 a\end{array}$ & $\begin{array}{c}3700 \\
\pm 223 \mathrm{~b}\end{array}$ & $\begin{array}{l}112 \\
\pm 5 \mathrm{a}\end{array}$ & $\begin{array}{c}3260 \\
\pm 242 \mathrm{a}\end{array}$ & $\begin{array}{c}24 \\
\pm 4 \mathrm{~b}\end{array}$ & $\begin{array}{l}1155 \\
\pm 69 a\end{array}$ & $\begin{array}{c}6 \\
\pm 2 \mathrm{ab}\end{array}$ & $\begin{array}{c}2325 \\
\pm 572 \mathrm{a}\end{array}$ & $\begin{array}{c}231 \\
\pm 50 \mathrm{a}\end{array}$ & $\begin{array}{c}10490 \\
\pm 1124 \mathrm{a}\end{array}$ \\
\hline $\begin{array}{l}\text { PLM-B2 } \\
\text { (Non- } \\
\text { Amended) }\end{array}$ & $\begin{array}{l}147 \\
\pm 5 \mathrm{c}\end{array}$ & $\begin{array}{c}7990 \\
\pm 1360 \mathrm{~b}\end{array}$ & $\begin{array}{c}58 \\
\pm 5 \mathrm{~b}\end{array}$ & $\begin{array}{c}3430 \\
\pm 242 \mathrm{~b}\end{array}$ & $\begin{array}{c}50 \\
\pm 2 b\end{array}$ & $\begin{array}{c}1010 \\
\pm 101 \mathrm{c}\end{array}$ & $\begin{array}{c}25 \\
\pm 6 b\end{array}$ & $\begin{array}{c}675 \\
\pm 65 \mathrm{~b}\end{array}$ & $\begin{array}{c}5 \\
\pm 1 b\end{array}$ & $\begin{array}{c}2077 \\
\pm 116 \mathrm{a}\end{array}$ & $\begin{array}{c}138 \\
\pm 24 b\end{array}$ & $\begin{array}{c}7211 \\
\pm 1245 b\end{array}$ \\
\hline $\begin{array}{l}\text { PLM-B3 } \\
\text { (Non- } \\
\text { Amended) }\end{array}$ & $\begin{array}{c}250 \\
\pm 11 \mathrm{~b}\end{array}$ & $\begin{array}{c}10700 \\
\pm 1210 \mathrm{a}\end{array}$ & $\begin{array}{c}89 \\
\pm 6 a\end{array}$ & $\begin{array}{c}5390 \\
\pm 264 a\end{array}$ & $\begin{array}{l}112 \\
\pm 3 a\end{array}$ & $\begin{array}{c}2270 \\
\pm 223 \mathrm{~b}\end{array}$ & $\begin{array}{c}38 \\
\pm 4 a\end{array}$ & $\begin{array}{c}466 \\
\pm 94 \mathrm{c}\end{array}$ & $\begin{array}{c}8 \\
\pm 1 \mathrm{a}\end{array}$ & $\begin{array}{c}2464 \\
\pm 471 \mathrm{a}\end{array}$ & $\begin{array}{c}247 \\
\pm 47 \mathrm{a}\end{array}$ & $\begin{array}{c}10649 \\
\pm 2036 \mathrm{a}\end{array}$ \\
\hline $\begin{array}{c}\text { PLM-B4 } \\
\text { (Amended) }\end{array}$ & $\begin{array}{c}69 \\
\pm 2 d\end{array}$ & $\begin{array}{c}4650 \\
205 \pm c\end{array}$ & $\begin{array}{c}14 \\
\pm 4 \mathrm{c}\end{array}$ & $\begin{array}{c}2880 \\
\pm 247 \mathrm{c}\end{array}$ & $\begin{array}{c}5 \\
\pm 2 \mathrm{c}\end{array}$ & $\begin{array}{c}233 \\
\pm 66 \mathrm{~d}\end{array}$ & $\begin{array}{c}32 \\
\pm 2 \mathrm{a}\end{array}$ & $\begin{array}{c}350 \\
\pm 66 \mathrm{~d}\end{array}$ & $\begin{array}{c}3 \\
\pm 0.3 \mathrm{c}\end{array}$ & $\begin{array}{c}1431 \\
\pm 108 \mathrm{~b}\end{array}$ & $\begin{array}{c}55 \\
\pm 13 \mathrm{c}\end{array}$ & $\begin{array}{c}4911 \\
\pm 1229 \mathrm{c}\end{array}$ \\
\hline
\end{tabular}

Bureau of Common References Revised (Four-Step) Sequential Extraction Protocol (Rauret and others, 1999) was used to determine

fractionation/ pseudototal; Non-Amended - collected outside "test-plots" from a non-amended location; Amended - collected within "Test-

Plots" and have received a regime of amendments; Values $(n=3)$ are means \pm SD. Means followed by the same letters within fractions are not

significantly different $(\mathrm{p}<0.05)$ defined by Tukey Kramer Method 

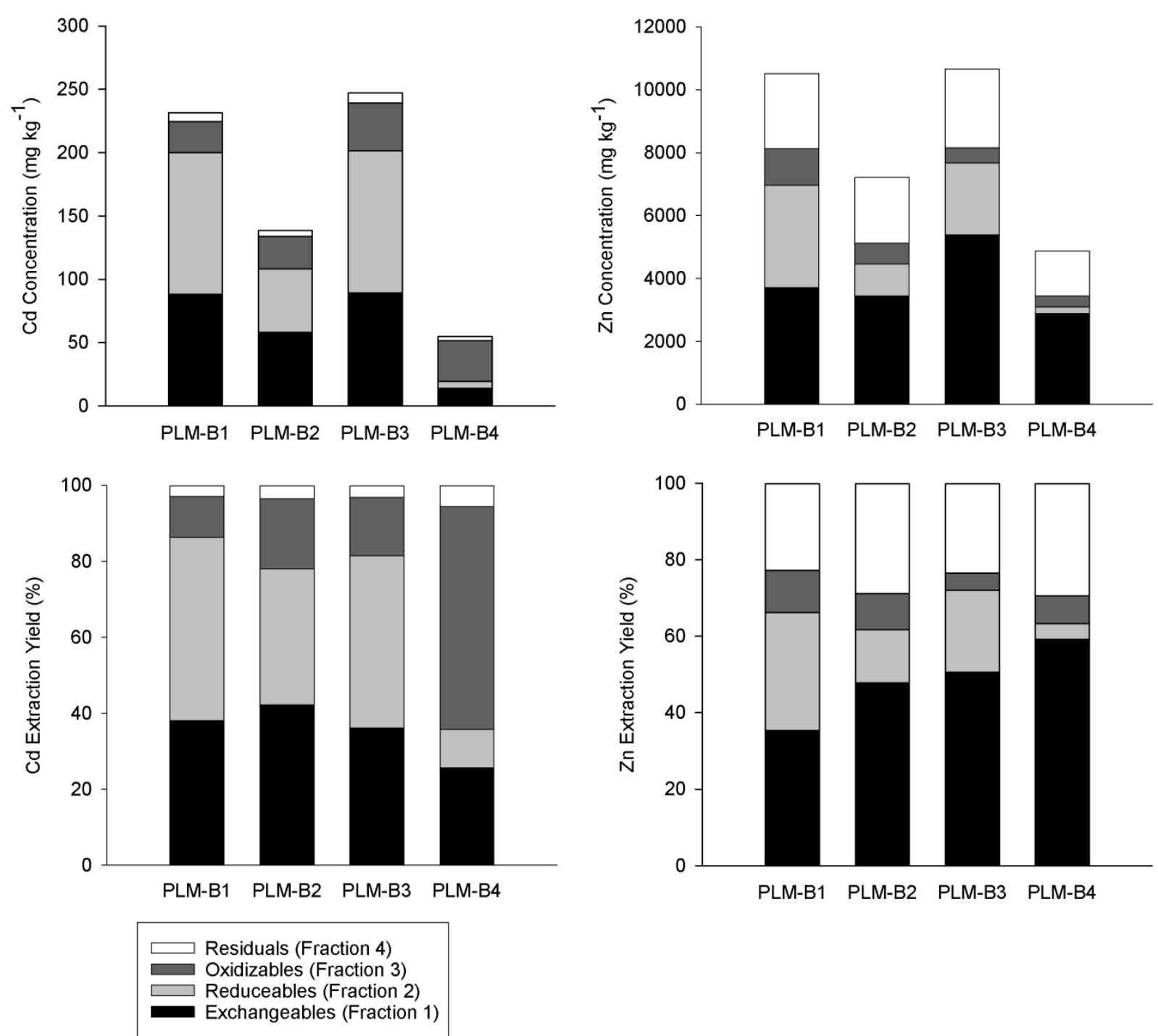

Figure 2.1 Revised BCR Sequential Extraction results from LGWR, Palmerton, PA soils. Results presented are means of replicate analysis $(n=3)$. 

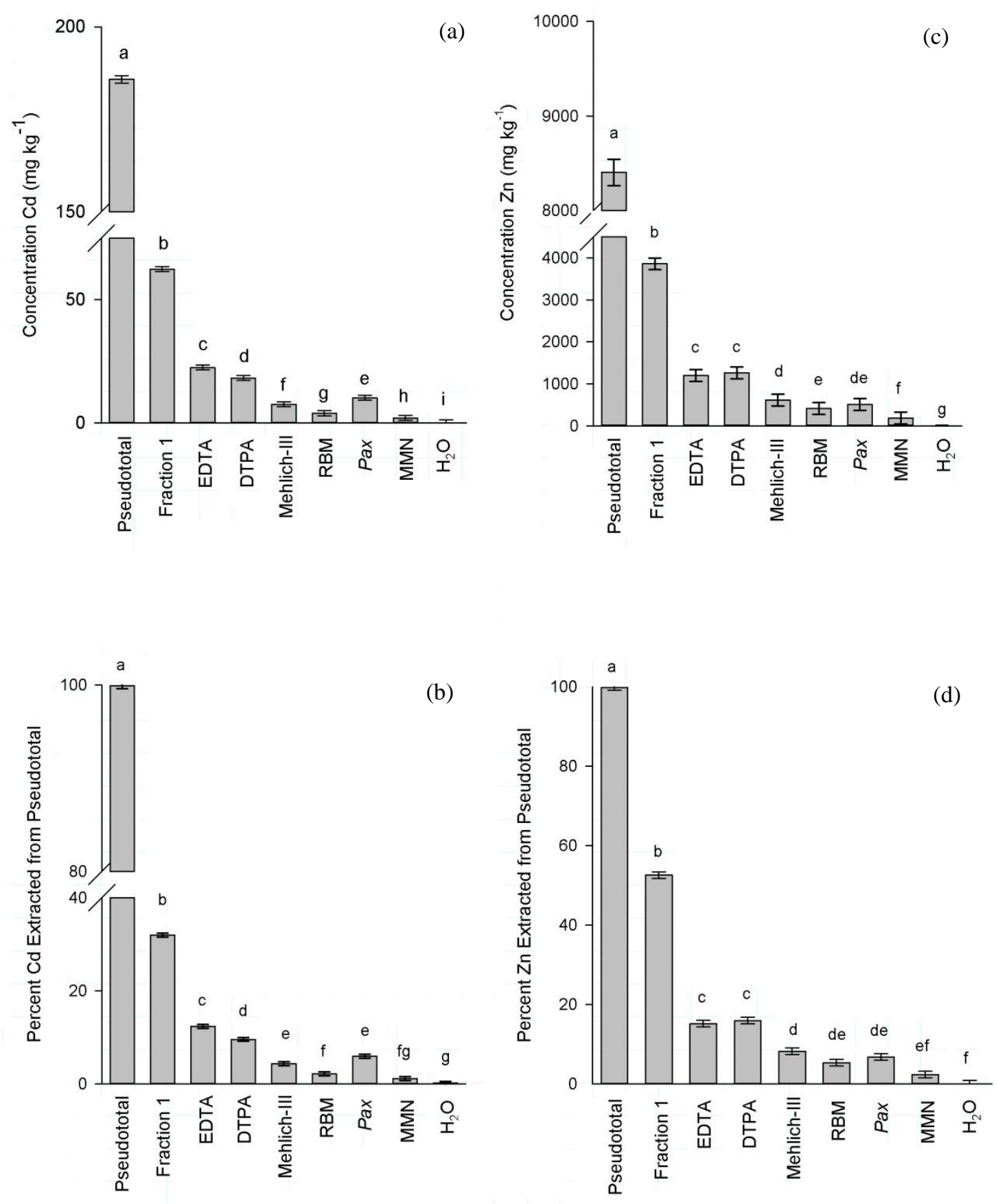

Figure 2.2 Plant Availability by extractant, where a weighted average across all samples was utilized to determine the overall efficiency of each extractant to estimate plant nutrient availability $(n=12)$. Means \pm SE followed by the same letters within rows are not significantly different $(\mathrm{p}<0.05)$. 


\section{Effect of Paxillus involutus on fractionation and uptake by Populus hybrid of zinc and cadmium in zinc-smelter contaminated soils}

\subsection{INTRODUCTION}

Contamination of soils and water with heavy metals is a worldwide problem. Anthropogenically-released metals are of major concern because of their availability, toxicity, and persistence in ecosystems. Approximately 3,000 tons of cadmium (Cd) and 52,000 tons of zinc $(\mathrm{Zn})$ are released every year in air and water by mining and smelting activities (UNEP, 2011). Both of these metals have the capacity for acute and long-term effects in humans including high reproductive and developmental implications, organ failure, and potential cancer initiators.

Active and past smelting of metalliferous ores has led to large accumulations of metals in surrounding landscapes due to atmospheric deposition. One such area found in east central Pennsylvania, USA, surrounding the New Jersey Zinc Smelter in Palmerton, PA. Although smelting ceased in the 1980 's, extensive soil contamination eliminated vegetation from the surrounding mountains. Such "hot-spots" act as areas of nonpoint source pollution, where metalcontaminated soil particles may be mobilized through erosion processes or metals may leach to groundwater or adjacent to water bodies. Typical methods of ameliorating metal-contaminated soils include soil washing with chemical extractants, electromechanical stripping, excavation and removal, and capping (Adriano, 2001). Such engineering approaches to remediation are expensive, prone to mobilizing metals, and may be impractical in certain landscapes. Additional limitations of the mechanical/chemical amelioration approaches include the loss of soil nutrients, organic matter, and microbial communities in the soil that are critical for ecosystem function.

Plant-assisted bioremediation (phytoremediation) is a low cost, effective means for ameliorating metal-contaminated sites (McGrath et al., 2001; McIntyre, 2003; Khan, 2005). Phytostabilization and phytoextraction have been recognized as approaches to reduce metal mobility and toxicity in the environment. The establishment of vegetative cover on metalcontaminated sites will reduce wind and water erosion, reducing the flux of contaminant metals 
to other ecosystems. Furthermore, phytoremediation creates possibilities for harvesting biomass and metals within the biomass and reduce site-specific metal loads (Chaney et al., 2007). In addition, the use of phytoremediation technologies may be more effective over extensive areas or in terrain that is unsuitable for standard engineering approaches. For example, in Germany, farmers used metal accumulating willow varieties to mitigate cadmium-contaminated farmlands, where soils were returned to vegetative production within a period of 6 years (Lebeau et al., 2008).

Gaining a greater understanding and exploiting the synergies that exist between plants and soil symbiotic microorganisms may prove effective in metal contaminated soil remediation efforts. Mycorrhizal fungi (both ectomycorrhizae and arbuscular mycorrhizae) have shown excellent efficacy in reducing metal toxicity to plant hosts (Hartley et al., 1997; Godbold et al., 1998).These symbionts assist in ameliorating toxicity of metals by transforming and sequestering these metals within the rhizosphere and intracellularly within fungal tissues (Gadd, 2001; Hall, 2002; Bellion et al., 2006; Meharg, 2003). Extracellularly, metal immobilization can be accomplished when metal ions bind to the complex macromolecular compounds that comprise the cell wall (biosorption). Precipitation and chelation of toxic metals may also occur by interactions with low-molecular-weight ligands produced by microbes as metal detoxification mechanism (Gadd, 1993; Johansson et al., 2008). Intracellular detoxification predominately relies on the internal sequestration of toxic metals by metal-induced molecules, such as metallothioneins and phytochelatins (Inouhe, 2005).

Paxillus involutus, a common ectomycorrhizal fungus, has been shown to ameliorate metal toxicity to its host species by alleviating metal stress through a myriad of pathways (Fomina et al., 2005; Denny and Wilkins, 1987; Ott et al., 2002; Hegedús et al., 2007; Blaudez et al., 2000). Formation of thiol-containing compounds from cysteine and its derivatives $(\gamma-$ glutamylcysteine, glutathione) and higher molecular mass compounds metallothioneins due to exposure with cadmium was observed in cytosolic fluids of $P$. involutus as a means to curb metal toxicity (Courbot et al., 2004). Schützendubel and Polle (2002) discuss how mycorrhizae protected pine roots against the negative effects of $\mathrm{Cd}$, where no significant change in fresh 
biomass due to $\mathrm{Cd}$ treatment was experienced, when seedlings were $80 \%$ associated with a wild strain of $P$. involutus isolated from metal contaminated site.

Accumulation of $\mathrm{Cd}$ and $\mathrm{Zn}$ is well documented in Populus spp. (Dos Santos Utmazian et al., 2007; Gadd, 2001). Tree species within the genus Populus are good candidates for rehabilitating contaminated sites due to their ability to accumulate relatively high concentrations of metals, easy propagation, deep root nature, adaptability to most soils, and high growth rates (Chaney et al., 2007). Although not recognized as a hyperaccumulator, hybrid poplar has increasingly become a model organism for phytoremediation (Wu et al., 2010). Phytostabilization of metals by poplar may occur through increases in soil organic matter, root exudation that may cause metal precipitation and toxicity/mobility, sorption to root surfaces, as well as uptake and intercellular sequestration (Wenzel et al., 2004; Wenzel, 2009; Gratão et al., 2005). Poplar grown in soils amended with metal-resistant mycorrhizae such as $P$. involutus may present a promising approach for metal stabilization in contaminated soils, reducing the potential for environmental harm while being economically feasible (Krpata et al., 2009; Sell et al., 2005).

Sequential extraction is a useful, indirect approach for identifying the behavior of potentially toxic metals in soils by operational speciation (Bacon and Davidson, 2009). Little work has been done utilizing sequential extraction in greenhouse or in situ experiments monitoring the "before" and "after" effects of trees or their symbiotic mycorrhizal fungi on metal fractionation in contaminated soils. Tao et al. (2005) recognized that the complexity of soil-plant interactions alter physiochemical parameters of the rhizosphere, which may lead to fractionation changes. Furthermore, chelate-assisted phytoextraction using a chelating agent (EDTA) has been used with Taraxacum officinale to increase in the proportion of analytes recovered from available fractions and increase the uptake of metals by the plant (Massop et al., 2009). No work has explored the effects of mycorrhizal relationships on fractionation changes of metals in soils. As the vast majority of higher plants are mycorrhizal, understanding the influence of mycorrhizae on metal fractionation is important in elucidating metal behavior in re-vegetating soils contaminated by metals. 
In the present study, we present the application of the European Commission, Community Bureau of Reference (BCR) sequential extraction procedure to observe changes in fractionation in two contaminated soils from an abandoned zinc-smelter site. These soils were utilized in a greenhouse experiment with a Populus hybrid ( $P$. deltoides x $P$. trichocarpa) and the ectomycorrhizal fungus $P$. involutus. During the greenhouse experiment, leachate was collected to monitor leaching of analytes of interest. The fractionation patterns of $\mathrm{Cd}$ and $\mathrm{Zn}$ before and after plant/fungal growth were assessed by the revised BCR three-step sequential extraction method to gain insight into how operational fractions were altered by poplar and its ectomycorrhizal symbiont.

\subsection{MATERIALS AND METHODS}

\subsubsection{Soil samples}

Soil samples were collected from the Lehigh Gap Wildlife Refuge and Nature Center (LGWR) located at the Palmerton Zinc Superfund Site in Palmerton, Pennsylvania, U.S.A. Four soil samples were collected from different locations within the LGWR. A sample was collected from a preexisting test plot and the others gathered from a non-amended area. The amended test plot is one of many plots on site that had been amended with various fertilizers, mushroom compost, and a warm season grass mix. The site is located adjacent to a historical zinc smelter(s) that had been in operation for nearly a century and has subsequently been turned into USEPA Superfund Site following the closure of both facilities. Activity at these smelters has led to the defoliation of approximately $8.1 \mathrm{~km}^{2}$ (2000 acres) in the vicinity (USEPA, 1987) mostly due to aerial deposition of potential toxic elements cadmium, lead, and zinc. The landscape is mostly a boulder field developed in the last Pleistocene glaciations (Pazzaglia et al., 2006) where little to no soil has developed. Samples were gathered from the top 0-10 cm depth in between boulders.

\subsubsection{General soil characterization}

Soil pH was measured using a 1:1 soil slurry with deionized water and air-dried soil (Thomas, 1996). Organic matter content was measured by loss in ignition at $500{ }^{\circ} \mathrm{C}$. Cation 
exchange capacity was determined using the compulsive exchange reaction (Hendershot and Duquette, 1986). Soil samples (2 g) were weighed and placed into 50-mL centrifuge tubes. The first centrifuge washing step with $20 \mathrm{~mL}$ of $24 \mathrm{~g} / \mathrm{L} \mathrm{BaCl}_{2} 2 \mathrm{H}_{2} \mathrm{O}$ was followed by three independent washing steps with $20 \mathrm{~mL}$ of $6 \mathrm{~g} / \mathrm{L} \mathrm{BaCl}_{2} \cdot 2 \mathrm{H}_{2} \mathrm{O}$, each executed for a $2 \mathrm{hr}$ period on a shaker table at $150 \mathrm{rpm}$. Samples were then subjected to a single overnight mixing-step with 20 $\mathrm{mL}$ of $3 \mathrm{~g} / \mathrm{L} \mathrm{MgSO}_{4}$. The mixture was then centrifuged at 2500 x $\mathrm{g}$ for $10 \mathrm{~min}$, followed by decanting and filtration of the supernatant with a $0.45-\mu \mathrm{m}$ Whatman syringe filter. Filtrates were stored at $4{ }^{\circ} \mathrm{C}$ until analysis.

Measurements of extractability of $\mathrm{Cd}$ and $\mathrm{Zn}$ were made using three single-batch extraction techniques to gather more understanding of bioavailability of these elements. Matúš et al. (2007) developed a simple method using EDTA and DTPA to determine phytoavailable concentrations of $\mathrm{Al}$ in environmental samples. We modified this technique to be utilized for determination of the $\mathrm{Cd}$ and $\mathrm{Zn}$, where none of the experimental methods were changed. Mehlich-III extraction, a more commonly used method was also employed to evaluate levels of available $\mathrm{Cd}$ and $\mathrm{Zn}$ in soils and their potential for phytoavailability (Mehlich, 1984). All three extractions gave a proxy of the amount $\mathrm{Cd}$ and $\mathrm{Zn}$ that can be easily removed by relatively weak extractants.

\subsubsection{Fungal culture}

Paxillus involutus (ATCC 200175) was grown on a modification of modified MelinNorkrans (MMN) agar media. The MMN media contained the following: $10 \mathrm{~g} / \mathrm{L}$ glucose, 0.26 $\mathrm{g} / \mathrm{L}\left(\mathrm{NH}_{4}\right)_{2} \mathrm{HPO}_{4}, 0.54 \mathrm{~g} / \mathrm{L} \mathrm{KH}_{2} \mathrm{PO}_{4}, 0.06 \mathrm{~g} / \mathrm{L} \mathrm{MgSO}_{4}, 0.11 \mathrm{~g} / \mathrm{L} \mathrm{CaCl}_{2}, 1.5 \mathrm{mg} / \mathrm{L} \mathrm{NaCl}, 1.9 \mathrm{mg} / \mathrm{L}$ $\mathrm{KCl}, \quad 0.77 \mathrm{mg} / \mathrm{L} \quad \mathrm{H}_{3} \mathrm{BO}_{3}, \quad 0.17 \mathrm{mg} / \mathrm{L} \quad \mathrm{MnSO}_{4} * \mathrm{H}_{2} \mathrm{O}, 0.29 \mathrm{mg} / \mathrm{L} \quad \mathrm{ZnSO}_{4} * 7 \mathrm{H}_{2} \mathrm{O}, 0.062 \mathrm{mg} / \mathrm{L}$ $\mathrm{CuSO}_{4} * 5 \mathrm{H}_{2} \mathrm{O}, 0.060 \mathrm{mg} / \mathrm{L} \mathrm{Na}_{2} \mathrm{MoO}_{4}, 0.060 \mathrm{mg} / \mathrm{L} \mathrm{CoCl}_{2} * 6 \mathrm{H}_{2} \mathrm{O}, 4.2 \mathrm{mg} / \mathrm{L} \mathrm{Fe}, \mathrm{Na}-\mathrm{EDTA}, 1 \mathrm{mg} / \mathrm{L}$ thiamine $\mathrm{HCl}, 0.41 \mathrm{mg} / \mathrm{L}$ pyridoxine $\mathrm{HCl}, 1.1 \mathrm{mg} / \mathrm{L}$ ascorbic acid, and $4.9 \mathrm{mg} / \mathrm{L}$ nicotinic acid (Cumming et al., 2001). The $\mathrm{pH}$ of the media was adjusted to 5 using hydrochloric acid and 10 g/L of agar was added before autoclaving. Following four weeks of growth on solid media, fungal colonies were transferred to $250-\mathrm{mL}$ conical flasks containing $\sim 50 \mathrm{~mL}$ of liquid $\mathrm{MMN}$ 
media with an additional $14 \mathrm{mg} / \mathrm{L} \mathrm{Zn}$ treatment. These cultures were to generate fungal inocula for greenhouse experiment with Populus.

\subsubsection{Growth experiment}

Before planting, two field-collected soils that had been sun-dried were separately homogenized in a cement mixer and sieved with a 10-mm aperture wire mesh. Common unrooted hybrid poplar DTAC-7 (Populus trichocarpa Torr. and Gray $\times$ Populus deltoides Marsh.) were used in this experiment and purchased from hybrid poplar grower (Segal Ranch, Granview, WA). Plants were watered with a modified artificial rain solution (Lee and Weber, 1979) containing $1.6 \mathrm{~g} / \mathrm{L}\left(\mathrm{NH}_{4}\right)_{2} \mathrm{SO}_{4}, 0.85 \mathrm{~g} / \mathrm{L} \mathrm{NaNO}_{3}, 1.6 \mathrm{~g} / \mathrm{L} \mathrm{CaCl}_{2} 2 \mathrm{H}_{2} \mathrm{O}, 0.40 \mathrm{~g} / \mathrm{L} \mathrm{KNO}_{3}, 1.3$ $\mathrm{g} / \mathrm{L} \mathrm{Mg}\left(\mathrm{NO}_{3}\right)_{2} 6 \mathrm{H}_{2} \mathrm{O}$, and $0.68 \mathrm{KH}_{2} \mathrm{PO}_{4}$. Watering of pots with artificial rain solution was conducted daily, where initially each received approximately $15 \mathrm{~mL}$. Subsequently after placing pots beneath lamps, watering was conducted twice a day to encourage growth and minimize water loss due to transpiration.

The greenhouse experiment was conducted over an 8-week period in a climate-controlled glasshouse. Plants were grown in 5 -cm diameter $\times 17.5 \mathrm{~cm}$ deep pots ('Cone-tainers' ${ }^{\mathrm{TM}}$, Stuewe and Sons, Corvallis, OR) with fine mesh screening at the bottom to minimize loss of soil. Pots containing no poplar cuttings or mycorrhiza (untreated $=u$ ), containing mycorrhiza $($ myc), were established in triplicate $(n=3)$. Pots containing poplar cuttings and lacking mycorrhiza (poplar = pop) and cutting with mycorrhiza (pop x myc) each had a sample size of $n=16$. Cuttings approximately $15 \mathrm{~cm}$ in length and $5 \mathrm{~mm}$ in diameter were inserted into pots that were filled with approximately $0.035 \mathrm{~kg}$ of acid-washed course-grained sand to encourage proper drainage and filled to the rim with approximately $0.240 \mathrm{~kg}$ of soil. Pots with mycorrhiza treatment were first filled three-quarters full with soil then an aliquot of $40 \mathrm{~mL}$ of fungal slurry, containing both the fungal tissue plus MMN. In addition, five plugs (1-cm in diameter) were added to encourage colonization. Following fungal inoculation, the pots were filled to the rim and weighed. Cuttings were grown in a climate-controlled greenhouse with supplemental lighting providing a 14-h photoperiod (mixed metal halide source) and day and night temperatures of $24 / 19 \pm 3{ }^{\circ} \mathrm{C}$. Relative humidity fluctuated with temperature and day. 
As leaves began to be lost, they were collected and retained for analysis. At the end of the greenhouse experiment, remaining leaves were removed and were amassed with fallen leaves per individual pot. Soil was washed from roots with deionized water by hand. Both the leaves and roots were oven dried at $60^{\circ} \mathrm{C}$ and stored until analysis, and soils were air-dried at room temperature.

\subsubsection{Digestion of plant and soil}

Plants analysis was accomplished by washing shoots and roots with deionized water, drying leaves and roots at $60{ }^{\circ} \mathrm{C}$ and grinding to pass through a 20-mesh sieve. Both shoots and roots were digested by microwave-assisted digestion. Plant material $(0.1 \mathrm{~g})$ was digested in 5-mL of $70 \% \mathrm{HNO}_{3}$ and $2 \mathrm{~mL}$ of $30 \% \mathrm{H}_{2} \mathrm{O}_{2}$ and allowed to react overnight. The samples were then microwave digested at $200^{\circ} \mathrm{C}$ for $1.5 \mathrm{hr}$. The digested solutions were passed through a $0.45-\mu \mathrm{m}$ Whatman syringe filter.

Pseudototal concentrations of soils were determined of field-collected soils and rhizosphere soils collected following the greenhouse experiment. Soils were air-dried, passed through a 2-mm sieve, placed in closed Teflon digestion vessels, and were subject to microwaveassisted digestion in a MARSXpress system (CEM USA, Matthews, NC). Samples (3 g) were digested with $28 \mathrm{~mL}$ of aqua regia $\left(3: 1\right.$ mixture of $37 \% \mathrm{HCl}$ and $70 \% \mathrm{HNO}_{3}$ ) at room temperature for $16 \mathrm{hr}$. Subsequently, the samples were then transferred to the microwave digester at $130{ }^{\circ} \mathrm{C}$ at reflux conditions for $2 \mathrm{~h}$. The supernatant was then filtered through a $0.45-\mu \mathrm{m}$ Whatman syringe filter and diluted to $100 \mathrm{~mL}$ with $0.5 \mathrm{M} \mathrm{HNO}_{3}$ and stored in polyethylene bottles at $4{ }^{\circ} \mathrm{C}$ until analysis.

\subsubsection{Sequential extraction}

Both native and pot experiment rhizosphere air-dried soils were subjected to the revised (four-step) sequential extraction protocol developed by the Bureau of Common References (Rauret et al., 1999). Each soil sample was extracted in triplicate. The $\mathrm{pH}$ of the extractant was 
measured at the beginning and end of the agitation of the sample in each step, excluding step 4. All the extractants from each step were passed through a $0.45-\mu \mathrm{m}$ Whatman syringe filter and refrigerated at $4{ }^{\circ} \mathrm{C}$ until analysis.

Step 1 (water/acid soluble and exchangeable fraction): $1 \mathrm{~g}$ sample was treated with 40 $\mathrm{mL}$ of $0.11 \mathrm{M}$ HOAc solution and was agitated on an orbital mixer at $30+/-10 \mathrm{rpm}$ for $16 \mathrm{hr}$ at room temperature. Separation of the supernatant was accomplished by centrifugation at $3000 \mathrm{X} \mathrm{g}$ for $20 \mathrm{~min}$. Following the removal of the supernatant, a washing step with $20 \mathrm{~mL}$ of deionized water for $15 \mathrm{~min}$ on the orbital mixer and centrifuged at $3000 \mathrm{Xg}$ for $20 \mathrm{~min}$. The supernatant was then decanted and discarded.

Step 2 (reducible fraction): The solid residue from the previous step was subjected to 40 $\mathrm{mL}$ of $0.5 \mathrm{M} \mathrm{HONH}_{2} \mathrm{HCl}$ solution, adjusted to a $\mathrm{pH}$ of 1.5 with a fixed volume of $2 \mathrm{M}$ $\mathrm{HNO}_{3}$. The sample was agitated on an orbital mixer at $30 \mathrm{t} /-10 \mathrm{rpm}$ for $16 \mathrm{hr}$ at room temperature. The supernatant and residue was separated similarly as the first step. The residue was washed in the same fashion as the previous step and the supernatant was decanted and discarded.

Step 3 (oxidizible fraction): The residue from step 2, $10 \mathrm{~mL}$ of $8.8 \mathrm{M} \mathrm{H}_{2} \mathrm{O}_{2}$ solution was added. The slurry was digested for $1 \mathrm{hr}$ at room temperature and placed on a block digester for $1 \mathrm{hr}$ at $85+/-5{ }^{\circ} \mathrm{C}$, and the volume was reduced to less than $3 \mathrm{~mL}$. An additional $10 \mathrm{~mL}$ of $\mathrm{H}_{2} \mathrm{O}_{2}$ solution was added and was digested for $1 \mathrm{hr}$ at $85+/-5^{\circ} \mathrm{C}$, and the volume was reduced to approximately $1 \mathrm{~mL}$. The extraction was accomplished by the addition of $50 \mathrm{~mL}$ of $1 \mathrm{M} \mathrm{NH}_{4} \mathrm{OAc}$ to the slurry where it was agitated on an orbital mixer at $30 \mathrm{t} /-10 \mathrm{rpm}$ for $16 \mathrm{hr}$ at room temperature. The supernatant and residue was separated similarly as the first step. The residue was washed in the same fashion as the previous step and the supernatant was decanted and discarded.

Step 4 (residual fraction): The residue from the previous step was digested by aqua regia, however the volumes of $\mathrm{HCl}$ and $\mathrm{HNO}_{3}$ used have been reduced to $7 \mathrm{~mL}$ and $2.3 \mathrm{~mL}$, respectively. The mixture was digested similarly as the Pseudototal determination. 


\subsubsection{Analyses and quality control}

All glassware and plasticware were washed with $0.2 \mathrm{M} \mathrm{HCl}$ and allowed to soak overnight and rinsed with nanopure water. All reagents were of analytical grade. Concentrations of $\mathrm{Cd}, \mathrm{Zn}$, and $\mathrm{Mg}$ were determined using a Varian 220FS atomic absorption spectrometer (Varian Inc., Mulgrave, Vic., Australia). Blanks were included in microwave digestions and sequential extractions, and quality of analysis was analyzed by spike and recovery. BCR CRM 701 was analyzed by BCR procedure, to ensure proper extraction using the BCR revised method. NIST SRM 1515 was used to ensure proper digestion of leaves using microwave digestion. Comparison between summed fractions of the sequential extraction and the Pseudototal of a separate aqua regia digestion were compared to determine the effective extractability of the analytes of concern, as recommended by Rauret et al. (1999).

The Translocation Factor (TF) was calculated using the final root and shoot metal concentrations $\left(\mathrm{TF}=[\mathrm{M}]_{\text {Shoot }} /[\mathrm{M}]_{\text {Root }}\right)$. Biomass was calculated using the final root and shoot mass $($ Biomass $=$ Root Mass + Shoot Mass). Shoot and root ratio was calculated using final root and shoot mass (Shoot:Root $=$ Shoot Mass/Root Mass). Total metal accumulation was calculated for each treatment by multiplying the dry weight of shoots $(\mathrm{kg})$ by the metal concentration in the shoots $(\mathrm{mg} / \mathrm{kg})$.

Statistical analysis used to determine the effects of mycorrhizae vs. non-mycorrhizae on plant mineral content were analyzed by two-way analysis of variance (ANOVA) separately per soil type, followed by Tukey-Kramer's HSD test (significance level of $P<0.05$ ) to identify significant difference between plant content and response means. Statistical analysis was used also to determine the effects of mycorrhizae and poplar on soil mineral content using a two-way ANOVA soil type, followed by a Tukey Kramer's HSD test (significance level of $P<0.05$ ) to identify significance between soil content and response means. Statistical analyses were carried out using SAS JMP 9.0 (SAS Institute, Cary, NC). 


\subsection{RESULTS}

\subsubsection{Soil characteristics}

Soils collected from the LGWR were heavily contaminated with both $\mathrm{Cd}$ and $\mathrm{Zn}$. Samples collected from various locations within the LGWR exceed typical concentrations of both $\mathrm{Cd}$ and $\mathrm{Zn}$ in instances where these levels exceed 15- and 130 -fold, respectively (Table 3.1). All soils exceed concentrations that warrant remedial action set by the USEPA (USEPA, 2001). Soil $\mathrm{pH}$ values of samples collected show mild acidity, a product of parent materials from which the soils originated (Web Soil Survey USDA NRCS). The two soils used PLM-B2 (nonamended) and PLM-B4 (amended) that proved to be less phytotoxic contained less TOC and had much less CEC then the two soils omitted (both non-amended), which displayed phytotoxicity to poplars grown in these soils. Common soil extraction methods were used to determine the bioavailability of both $\mathrm{Cd}$ and $\mathrm{Zn}$. Both the EDTA and DTPA extractions tended to remove similar concentrations of each analyte from each substrate. Mehlich-III extraction showed to be similar to the other extraction values only for PLM-B4, where for the other soils this extraction varied greatly and underestimated bioavailability by 2 - to 3 -times less.

\subsubsection{Quality control}

The recoveries of analytes $(\mathrm{Cd}$ and $\mathrm{Zn})$ using spike and recovery in extracts and digests were $100 \pm 20 \%$. Recovery of analytes (Cd and $\mathrm{Zn}$ ) from BCR CRM 701 from each batch sequential extraction was $100 \%$. The recovery of analytes $(\mathrm{Cd}$ and $\mathrm{Zn})$ from the $\mathrm{BCR}$ extraction procedure, where combining the individual steps and comparing amounts detected to the results of a separate aqua regia digest, ranged from $73 \%$ to $144 \%$. The recovery of analytes ( $\mathrm{Cd}$ and $\mathrm{Zn}$ ) from NIST SRM 1515 apple leaves standard to determine the completeness of microwave digestion of plant materials was $90 \%$. 


\subsubsection{Tree growth and plant metal concentrations}

Tree growth in soils was limited to two soils (PLM-B2 and PLM-B4). The remainder of this discussion will only mention the results of these soils and will be referred to as non-amended and amended, respectively. Table 3.2 contains all greenhouse experiment information regarding growth and concentrations of $\mathrm{Zn}$ and $\mathrm{Cd}$ in both roots and shoots. Biomass showed to be greatest in poplars grown in amended soils $(\mathrm{p}<0.005)$. Mycorrhizal association proved to be effective in increasing biomass in both treatments $(\mathrm{p}<0.05)$. Root to shoot ratios was higher in amended soils $(\mathrm{p}<0.05)$, where root growth is higher in these soils however they showed no mycorrhizal effect.

Cadmium trends illustrate that treatment effects had greatest influence alleviating toxicity in poplars grown in amended soils. Mycorrhizal association in both treatments increased root and shoot $\mathrm{Cd}$ content. In $\mathrm{Cd}$ shoot content, all treatment effects were very significant $(\mathrm{p}<0.005)$, where for root content soil type $(\mathrm{p}<0.005)$ and mycorrhizal association $(\mathrm{p}<0.05)$ were the causation for success. The total content of $\mathrm{Cd}$ was affected greatest by mycorrhizal treatment $(\mathrm{p}<0.01)$ allowing for increased accumulation of $\mathrm{Cd}$ in shoots. The interactive effect of soil and mycorrhizal treatment $(\mathrm{p}<0.005)$ followed by mycorrhizal treatment $(\mathrm{p}<0.01)$ had the largest impact on the translocation of $\mathrm{Cd}$.

Zinc in plants showed that amended soils had greater success than non-amended soils in the outcome of zinc distribution. Zinc in shoots was greatest in amended soil, where in roots, zinc was highest in non-amended soil. In zinc shoot content, it was observed that mycorrhizal effect is significant $(\mathrm{p}<0.05)$ for the translocation of $\mathrm{Zn}$ to the aerial component of the host. The total content of $\mathrm{Zn}$ in the aboveground compartment was two-fold greater in amended versus non-amended soil. This trend is also observed in the translocation values for zinc, where amended soil plant treatments out compete non-amended soil treatments.

\subsubsection{Pseudototal metal concentrations}

Pseudototal (aqua-regia extractable) metal concentrations in soils used are tabulated in Table 3.3. $U$ indicated untreated (receiving only artificial rain solution), $M y c=$ addition of 
mycorrhizae to soil, Pop $=$ presence of Poplar, Myc $\times$ Pop $=$ addition of mycorrhizae and presence of Poplar. All soils were above criteria set by all regulatory values presented in Table 3.1 for both cadmium and zinc. However, these concentrations are less than reported by literature compiled from the USFWS report for Palmerton (USFWS, 2003). Results for untreated soil were consistent with the field sample exemplifying reproducibility of the aqua-regia extraction. Cadmium was highest in $U$ from amended soil, where in non-amended soil, $M y c$ contained highest concentration. Zinc was highest in $U$ and Pop x $M y c$ soils in both soil types. Overall reduction in concentration in both cadmium and zinc in both amended and non-amended soils was with Pop treatment. Soils were not appreciably deteriorated of both cadmium and zinc based on their pseudototal values, due to the small application of artificial rain solution to leach analytes and short growth period to allow significant root and shoot growth to deplete aqua-regia soluble soil metal content.

\subsubsection{Sequential extraction of greenhouse soils}

The Revised BCR Sequential Extraction scheme was used to determine how choice poplar and mycorrhizae could alter soils collected from the LGWR. Figure 3.2 and Figure 3.3 both illustrate fractionation (\%) change between treatments compared to the field sample. $\mathrm{Cd}$ fractionation for non-amended soil demonstrates an increase in exchangeable, reducible, and residual fractions as compared to Field Sample soil. In amended soil, all fractions besides the oxidizable component were altered significantly. The pool from which other fractions gain greatest $\mathrm{Cd}$ content from is from the oxidizable fraction, where the Field Sample contains 58\%, the other treatments range from 2-6\%. Zn fractionation for non-amended soil exhibits a decrease in exchangeable and residual fractions, with a general increase in both reducible and oxidizable fractions as compared to Field Sample soil. As for amended soil, exchangeables are reduced in all treatments and decrease in residual fraction for both Pop and Pop x Myc treatments ( 10\% reduction). Reducible fraction was increased in all treatments with exception of $U$.

Cadmium fractionation patterns in non-amended soils are shown in Figure 3.1. In Fraction 1, all treatments maintain or fell below the original concentration of the Field Sample, with exception to $M y c$ treatment. In the reducible Fraction 2, all treatments increase 
concentration of $\mathrm{Cd}$ with exemption to Pop treatment that showed a decrease in reducible Cd. In Fraction 3, all treatments reduced $\mathrm{Cd}$ in the oxidizable form, with the greatest decrease of $97 \%$ in $M y c$ treatment. In the remaining residual Fraction 4, all treatments with exception of Pop x Myc Treatment were greater than the original Field Sample, with maximum increases of a $100 \%$. The changes in Fractionation for amended soils are illustrated in Figure 3.1. As for Fraction 1, all treatments show an increase in $\mathrm{Cd}$, with a $192 \%$ increase in the greatest effected soil. In the reducible Fraction 2, all treatments have an increase in $\mathrm{Cd}$, with a $333 \%$ increase in the Pop $\mathrm{x}$ Myc Treatment that had the largest increase in $\mathrm{Cd}$ in this fraction. Fractional change in oxidizable Fraction 3, all treatments fell way below the original concentration of the Field Sample with average reduction overall treatments of 91\%. In Fraction 4, residual concentration increased significantly for treatments without poplar (Average over both non-poplar treatment of $316 \%$ increase in $\mathrm{Cd}$ ), where both treatments containing poplar maintained relative concentrations similar to the original Field Sample Cd concentration.

The fractionation patterns for $\mathrm{Zn}$ in non-amended soils are shown in Figure 3.2. In Fraction 1, all treatments had been altered and reduced compared to the Field Sample. In the reducible fraction, there was an increase in all fractions with all means showing similarities with exception to the $U$ treatment, with increases in $\mathrm{Zn}$ concentration up to $100 \%$. Fractionation change in the oxidizable fraction increased in all fractions with the greatest at $42 \%$ increase in $\mathrm{Zn}$. The residual fraction illustrates an overall decrease in $\mathrm{Zn}$ in all treatment with the greatest reduction of $\mathrm{Zn}$ in Pop x $M y c$. The fractionation patterns for $\mathrm{Zn}$ in amended soils are shown in Figure 3.3. Fraction 1 of the sequential extraction scheme exhibits an increase in all treatments with exception to the $M y c$ treatment. In Fraction 2, all treatments with exception to the $U$ treatment demonstrated an $\sim 300 \%$ increase in $\mathrm{Zn}$ compared to the Field Sample recorded value. In Fraction 3 the oxidizable component increased in all treatments, with greatest increase at $200 \%$ increase in $\mathrm{Zn}$ as established from the original Field concentration. In the remaining residual fraction, there was a split in fractionation change compared to soils with poplar and without. Soils grown with poplar saw a $39 \%$ decrease in $\mathrm{Zn}$, where soils grown without increased in $\mathrm{Zn}$ concentration. 


\subsubsection{Mobility of metals in soils}

In non-amended soils, metal mobility from the cones was initially high and declined markedly over time (Figure 3.4). Average concentrations for $\mathrm{Cd}$ in non-amended soils in leachate in the first week were $0.05 \mathrm{mg} / \mathrm{kg}$ and declined to $0.006 \mathrm{mg} / \mathrm{kg}$ after 60 days across all treatments. In these soils, with addition of $P$. involutus in the very short term ( $<4$ days) led to increased mobility, but then $\mathrm{Cd}$ export declined in these treatments for the rest of the experimental period. On a mass basis, Cd was most mobile from cones with $U$ and Pop treatments and declined with the addition of $P$. involutus to either cone containing the $M y c$ or Pop x Myc treatment. The sum total difference of $\mathrm{Cd}$ exported from cones due to the addition of $P$. involutus was $0.25 \mathrm{mg} / \mathrm{kg}$ from cones without poplar $(M y c)$ and $0.31 \mathrm{mg} / \mathrm{kg}$ with poplar cuttings (Pop x Myc). The sum total difference of Cd exported from cones without inoculation was $0.26 \mathrm{mg} / \mathrm{kg}$ for both treatments. The addition of poplar cuttings alone across all treatments on average leached $11 \%$ more $\mathrm{Cd}$ then cones without any poplar cuttings addition.

The average $\mathrm{Zn}$ concentrations in leachate in the first week were $2.1 \mathrm{mg} / \mathrm{kg}$ and declined to $0.48 \mathrm{mg} / \mathrm{kg}$ after 60 days across all treatments. In these soils, with addition of $P$. involutus in the very short term ( $<7$ days) led to increased mobility, but then $\mathrm{Zn}$ export declined in these treatments for the rest of the experimental period. On a mass basis, $\mathrm{Zn}$ was most mobile from cones with $U$ and Pop treatments and declined with the addition of $P$. involutus to either cone containing the $M y c$ or Pop x $M y c$ treatment. The sum total difference of $\mathrm{Zn}$ exported from cones due to the addition of $P$. involutus was $19.7 \mathrm{mg} / \mathrm{kg}$ from cones without poplar $(M y c)$ and 27.3 $\mathrm{mg} / \mathrm{kg}$ with poplar cuttings ( $P o p$ x $M y c$ ). The sum total difference of $\mathrm{Zn}$ exported from cones without inoculation was $24.5 \mathrm{mg} / \mathrm{kg}(U)$ and $29.8 \mathrm{mg} / \mathrm{kg}(P o p)$. The addition of poplar cuttings alone across all treatments on average leached $22 \%$ more $\mathrm{Zn}$ then cones without any poplar cuttings addition.

Concentrations on average for $\mathrm{Cd}$ in amended soils for leachate in the first week were $0.0092 \mathrm{mg} / \mathrm{kg}$ and dropped to $0.0016 \mathrm{mg} / \mathrm{kg}$ after 60 days across all treatments. Same conditions persisted for $\mathrm{Cd}$ as did $\mathrm{Zn}$ in these soils, metal mobility due to addition of $P$. involutus inoculum 
was significantly longer than non-amended soils ( 25-30 days). The sum total difference of Cd exported from cones due to the addition of $P$. involutus was $0.05 \mathrm{mg} / \mathrm{kg}$ from cones without poplar $(M y c)$ and $0.06 \mathrm{mg} / \mathrm{kg}$ with poplar cuttings (Pop x Myc). The sum total difference of Cd exported from cones without inoculation was $0.02 \mathrm{mg} / \mathrm{kg}(U)$ and $0.03 \mathrm{mg} / \mathrm{kg}$ (Pop). The addition of poplar cuttings alone across all treatments on average leached $19 \%$ more Cd then cones without any poplar cuttings addition.

As with amended soils, metal mobility was originally high with concentrations of $\mathrm{Zn}$ exceeding in the first week $0.84 \mathrm{mg} / \mathrm{kg}$ and declined to $0.094 \mathrm{mg} / \mathrm{kg}$ after 60 days across all treatments. However, in amended soils, the pattern of stimulated metal mobility due to addition of $P$. involutus inoculum was significantly longer than non-amended soils (Figure 3.4). Inoculation of soils alone, sustained $\mathrm{Zn}$ export for 15 days from cones containing Pop treatment, where in Pop x Myc treatment sustained $\mathrm{Zn}$ leaching occurred for duration of the experimental period. The sum total difference of $\mathrm{Zn}$ exported from cones due to the addition of $P$. involutus was $4.8 \mathrm{mg} / \mathrm{kg}$ from cones without poplar $(M y c)$ and $7.08 \mathrm{mg} / \mathrm{kg}$ with poplar cuttings (Pop $\mathrm{x}$ $M y c)$. The sum total difference of $\mathrm{Zn}$ exported from cones without inoculation was $3.85 \mathrm{mg} / \mathrm{kg}$ $(U)$ and $2.37 \mathrm{mg} / \mathrm{kg}(P o p)$. The addition of poplar cuttings alone across all treatments on average leached $9 \%$ more $\mathrm{Zn}$ then cones without any poplar cuttings addition.

\subsection{DISCUSSION}

Soils collected from the LGWR are extremely contaminated with $\mathrm{Cd}$ and $\mathrm{Zn}$ reflecting approximately 100 years of smelting that has led to the complete defoliation of the areas surrounding the two smelting facilities and the surrounding vicinities, including the community of Palmerton, PA (USEPA, 1987). It has been estimated that over the 80 years of smelting in the borough of Palmerton, approximately 3740 tons of $\mathrm{Cd}$ and 286,000 tons of $\mathrm{Zn}$ had been emitted through aerial deposition (USFWS, 2003). Total Cd and Zn from soils collected determined by aqua regia digest ranged 40 to $262 \mathrm{mg} / \mathrm{kg}$ and 4783 to $13503 \mathrm{mg} / \mathrm{kg}$, respectively. Based on batch extractions to determine extractability of $\mathrm{Cd}$ and $\mathrm{Zn}$, the effectiveness shows similar extractability by both EDTA and DTPA for both of these analytes (Figueroa, 2015). The Mehlich-III extraction, a standard method developed to evaluate levels of available micro- and 
macronutrients in soils in the southeastern USA (Mehlich, 1984), extracted nearly half than the other two extractants for $\mathrm{Zn}$ in non-amended soil PLM-B2, but removed equal amount of $\mathrm{Zn}$ in amended soil PLM-B4. Whereas for Cd, Mehlich III extraction removed approximately twothirds less Cd than EDTA and DTPA in PLM-B2 soil and half the amount for PLM-B4 soil. The amended soil (PLM-B4) had been amended with agricultural lime, fertilizer, mushroom compost, and turkey manure as part of a 56 one-acre test plots remediation plan in 2003 to evaluate the success of planting warm-season grasses to revegetate hillslope at the site. Results from the test plots in 2003 indicated that where mushroom compost was applied 63\% live plant cover existed and in 2004 over $81 \%$ coverage had been accomplished (Latham et al., 2007). In these soils it suggests that due to amending and plant growth the pool of $\mathrm{Cd}$ and $\mathrm{Zn}$ has been reduced by sequestration into vegetation and redistribution into less-labile forms as compared to soils collected outside of the test plots.

In two soils, PLM-B1 and B3, concentrations of heavy metals evidently exceeded levels to permit growth of poplar. These soils both contained the highest $\mathrm{Cd}$ and $\mathrm{Zn}$ concentrations across all soils collected (Table 3.1). In these soils, poplar cuttings initiated limited shoot elongation, but roots were unable to develop sufficiently to overcome the phytotoxicity of these soils and were not evaluated in the growth and 'after' soil experiments. When $\mathrm{Zn}$ and $\mathrm{Cd}$ is in large supply, inhibition of root elongation and chlorosis in young leaves are common (Marschner, 2002) and were observed in this study for poplar grown in these soils. In the remaining soils, PLM-B2 (non-amended) and B4 (amended), poplar cuttings became established and were aided by the application $P$. involutus inoculum and additionally influenced the uptake and mobility of metal in these soils (Table 3.2 and Figure 3.4). Across all treatments, plant growth was $62 \%$ greater in amended soil as compared to non-amended soil, with most allocated to root growth. With the addition of $P$. involutus inoculum plant growth increase $27 \%$ across the two soils focused on in this study. The shoot:root ratios of $\mathrm{Cd}$ and $\mathrm{Zn}$ were below the threshold of 1 (Table 3.2) and metals were mostly sequestered in the roots, which is typical of nonhyperaccumulating plants (McGrath et al., 2001). The "bioavailable" pools of $\mathrm{Cd}$ and $\mathrm{Zn}$ in these soils were significantly higher than the soils not used (PLM-B1 and B3) as determined by the summation of the first three-steps of the sequential extraction protocol (Bacon and Davidson, 2009), however this interpretation is not straightforward. Pooling all samples $\mathrm{R}^{2}$ values were 
0.91 for $\mathrm{Cd}$ (both tissue types) and 0.69 for $\mathrm{Zn}$ (both tissue types); for non-mycorrhizal treatment, $\mathrm{R}^{2}$ values were 0.95 for $\mathrm{Cd}$ and 0.57 for $\mathrm{Zn}$; and for mycorrhizal treatment, $\mathrm{R}^{2}$ values were 0.91 for $\mathrm{Cd}$ and 0.78 for $\mathrm{Zn}$.

The differences observed in treatments were driven by differences in availability of $\mathrm{Cd}$ and $\mathrm{Zn}$ in these soils. Zinc concentrations of roots in amended soils were less than that of nonamended soils, yet shoot $\mathrm{Zn}$ concentration was higher in amended soils. This pattern may be a result of increased growth and soil exploration of roots with lesser extractable Zn, where enhanced shoot growth and leaf area would lead to greater transpirational accumulation of $\mathrm{Zn}$ in leaves. This phenomenon may reflect that different species have morphological features associated with leaves that may alter and affect evapotranspiration, translating that to metal uptake rates and patterns of movement to new shoots (Dos Santos Utmazian et al., 2007; Hall, 2002). In general, it is believed natural $\mathrm{Zn}$ tolerance is by either exclusion or compartmentalization (McIntyre, 2003; Hammer and Keller, 2002), by organic acid exudation, cell wall immobilization, or vacuolar sequestration (Ryan et al., 2001; Qin et al., 2007). Through mycorrhizal symbiosis, it has been observed that alteration may occur in root-to-shoot translocation or preferential change in localities where $\mathrm{Zn}$ is stored extra-/intracellularly both within the host and symbiont (Jones et al., 2003; Krpata et al., 2009).

In contrast to $\mathrm{Zn}, \mathrm{Cd}$ concentrations in poplar roots and shoots were less in amended soils than in non-amended soils, suggesting that the treatment of soils with amendments warm-season grasses mentioned above may have altered the soil's structure and composition to improve the success of these pioneering species. The increasing of $\mathrm{pH}$ by liming, addition of organic matter from fertilizer and manure, and reintroduction of soil biota by inoculation with mushroom compost may have all led to the redistribution of heavy metals to a more favorable speciation increasing uptake by plants and soil biota or may have reduced the activity of metals by sequestration by complexation into in-/organic forms. Reclamation may have increased the bioavailability of $\mathrm{Cd}$ and its subsequent uptake and impact on poplar. This inference is based on increased TF values for both treatments, suggesting the increased translocation of $\mathrm{Cd}$ from the roots to shoots as compared to $\mathrm{Zn}$ (Table 3.2). This led to a $35 \%$ greater translocation of $\mathrm{Cd}$ overall treatments versus $\mathrm{Zn}$ in these soils. Inoculation of amended soils with $P$. involutus did 
lead to increased foliar and root concentrations, which may reflect a change in mobility and bioavailability of $\mathrm{Cd}$ in this treatment.

The synergistic properties of $\mathrm{Cd}$ and $\mathrm{Zn}$ make these two elements association unique in which they may display similar attributes and properties in biological systems. As seen in this experiment and others (Wu et al., 2010; Koopmans et al., 2008), greater translocation of Cd may be due to the following: active transport, lack of absorption by chelators either fixed or soluble in the soil-root interface, or interaction and competition with other divalent ions for root uptake (Das et al., 1997; Lorenz et al., 1997). Other responses mechanisms of higher plants to Cd include mechanisms described as means for $\mathrm{Zn}$ tolerance but also include the formation of phytochelatins, metallothioneins, peroxidases, stress proteins, and ethylene production (Sanità di Toppi et al., 1999; Prasad, 1995). These mechanisms are enacted to effectively cope with Cd stress through exclusion, detoxification, and damage repair onset by $\mathrm{Cd}$ interaction.

The fractionation of metals from soils collected from LGWR was altered by the growth of poplar and the introduction of P. involutus in the soils (Figure 3.1). Difference between the "Before" treatment (field collected soil) and the four other treatments reflect changes that occur in metal biogeochemistry from the activities of native microbes (" $U$ ") or introduced mycorrhizal fungi ("Myc" and 'Pop x Myc") or poplar ("Pop" and "Pop x Myc"). Bacon and Davidson (2009) address the usefulness and strength in sequential extraction when comparing 'before and after' application in monitoring general change in metal reactivity in operational fractions and to observe the effectiveness of the treatment used. In general, the use of soils in the greenhouse in any of the treatments led to decreases in extractable and residual $\mathrm{Zn}$ and increases in reducible and oxidizable $\mathrm{Zn}$ content. The increase of $\mathrm{Zn}$ in both reducible and oxidizable fractions (Figures 3.2 and 3.3) may reflect fluxes from the exchangeable and residual pools induced by biological activity and uptake. In contrast, $\mathrm{Cd}$ displayed an increase in the exchangeable, reducible, and residual fractions and a decrease in the oxidizable fraction. $\mathrm{pH}$ and organic matter are two of the most important factors in controlling Cd availability (Jastrow and Koeppe, 1980; Bradl, 2004; Adriano, 2001). Due to the properties of materials associated with the oxidizable fraction (organic matter), during plant growth this pool can be easily depleted due to high instability due to $\mathrm{pH}$ and biogeochemical cycling of carbon (Haung et al., 2005). In Canadian 
forest soils Kirkham (2006) reviews that the quality of soil organic matter may be the limiting factor on the ability to bind and accumulate $\mathrm{Cd}$. Due to the lack of vegetative cover and its persistence over time due to metallurgic smelting adjacent to the LGWR, this may be an explanation for the huge depletion of $\mathrm{Cd}$ seen in both amended and non-amended soils from this fraction.

\subsection{CONCLUSION}

The revised BCR sequential extraction method proved to be a valuable tool in assessing how poplar and Paxillus involutus can alter zinc smelter contaminated soils, increasing the likeliness of remediating sites similar to the one studied in this research. Fractionation patterns for $\mathrm{Zn}$ in non-amended soil showed an overall decrease in residual pool and increase in the residual pool for all treatments in comparison to the original field soil. Where in non-amended soils, fractionation patterns showed $\mathrm{Cd}$ was redistributed to the oxidizable pool and an increase in the reducible and residual pools when compared to the original field soil. In amended soil, the fractionation patterns for $\mathrm{Zn}$ had reductions in the exchangeable and reducible pools mostly in the Pop and Pop x Myc treatments. Cadmium was redistributed in amended soil the greatest, with a majority of the oxidizible pool being transferred to the reducible and exchangeable pools. This reflects the transfer of cadmium from soil to shoot and roots of the poplar used in this study. Leachate $\mathrm{Cd}$ and $\mathrm{Zn}$ concentrations released in this study from pots was overall insignificant in its effect on fractionation; however the concentrations released can be considered an environmental hazard.

Phytoremediation potential using poplar hybrids with desired symbiotic mycorrhizal fungi was achieved in this experiment, where amended soil from Palmerton allowed the highest translocation of metals, biomass, and root to shoot ratio. Treatment effects exhibited that the combination of poplar hybrid and Paxillus involutus used in this study had demonstrated greater efficacy in removing $\mathrm{Cd}$ from soils than $\mathrm{Zn}$. The mycorrhizal treatment in this study had little or no influence in translocating $\mathrm{Zn}$ from soil to shoots, but rather sequestered $\mathrm{Zn}$ within the roots of the poplar used, more so in non-amended soils than amended soils. Using either the concentrations determined by the first step or the sum of the first three steps of the sequential 
extraction method to determine the relationship with plant uptake that is used loosely in many studies to determining bioavailability should be used cautiously, however using this method showed to be significant in this soil-plant system studied.

\subsection{REFERENCES}

Adriano DC. Trace elements in terrestrial environments: biogeochemistry, bioavailability, and risks of metals. $2^{\text {nd }}$ Edition, New York, Springer-Verlag.

Bacon JR, Davidson CM. Is there a future with sequential chemical extraction? Analyst 2008; 133: 25-46.

Bellion M, Courbot M, Jacob C, Blaudez D, Chalot M. Extracellular and cellular mechanisms sustaining metal tolerance in ectomycorrhizal fungi. Federation of European Microbiological Societies Microbiological Letters 2006; 254: 173-181.

Blaudez D, Bottom B, Chalot M. Cadmium uptake and subcellular compartmentalization in the ectomycorrhizal fungus Paxillus involutus. Microbiology 2000; 146: 1109-1117.

Bradl, HB. Absorption of heavy metal ions on soils and soils constituents. Journal of Colloid and Interface Science 2004; 277: 1-18.

Broadley MR, White PJ, Hammond JP, Zelko I, Lux A. Zinc in Plants. New Phytologist 2007; 173: 677-702.

Chaney RL, Angle JS, Broadhurst CL, Peters CA, Tappero RV, Sparks DL. Improved understanding of hyperaccumulation yields commercial phytoextraction and phytomining technologies. Journal of Environmental Quality 2007; 36: 1429-1443.

Das P, Samantaray S, Rout GR. Studies on cadmium toxicity in plants: A review. Environmental Pollution 1997; 98: 29-36.

Denny HJ, Wilkins DA. Zinc tolerance in Betula spp., IV. The Mechanism of ectomycorrhizal amelioration of zinc toxicity. New Phytologist 1987; 106: 545-553.

Dos Santos Utmazian MN, Wieshammer G, Vega R, Wenzel WW. Hydroponic screening for metal resistance and accumulation of cadmium and zinc in twenty clones of willows and poplars. Environmental Pollution 2007; 148: 155-165.

Figueroa, CX. Cadmium and zinc partitioning in zinc smelter contaminated soils (Unpublished Masters Thesis), West Virginia University, Morgantown, WV. 2015. p. 25-46.

Formina MA, Alexander IJ, Colpaert JV, Gadd GM. Solubilization of toxic metal minerals and metal tolerance of ectomycorrhizal fungi. Soil Biology \& Biochemistry 2005; 37: 851866.

Gadd GM. Interactions of fungi with toxic metals. New Phytologist 1993; 124: 25-60.

Gadd GM. Metal Transformations. In: Gadd GM, editor. Fungi in bioremediation. New York: Cambridge University Press; 2001. p. 359-382.

Godbold DL, Jentschke G, inter S, Marschner P. Ectomycorrhizas and amelioration of metal stress in forest trees. Chemosphere 1998; 36: 757-762.

Gratão PL, Prasad MNV, Cardoso PF, Lea PJ, Azevedo RA. Phytoremediation: green technology for the cleanup of toxic metals in the environment. Braz. J. Plant Physiol. 2005; 17: 53-64. 
Hall JL. Cellular mechanisms for heavy metal detoxification and tolerance. Journal of Experimental Botany 2002; 53: 1-11.

Hammer D, Keller C. Changes in the Rhizosphere of Metal-Accumulating Plants Evidenced by Chemical Extraction. Journal of Environmental Quality 2002; 31: 1561-1569.

Hartley J, Cairney JWG, Meharg AA. Do mycorrhizal fungi exhibit adaptive tolerance to potentially toxic metals in the environment? Plant Soil 1997; 189: 303-319.

Hegedűs N, Emri T, Szilágyi J, Karányi Z, Nagy I, Penninckx MJ, Pócsi I. Effect of heavy metals on the glutathione status in different ectomycorrhizal Paxillus involutus strains. World Journal of Microbiology and Biotechnology 2007; 23: 1339-1343.

Hendershot WH, Duquette M. A simple barium chloride method for determining cation exchange capacity and exchangeable cations. Soil Science Society of American Journal 1986; 50: 605-608.

Huang P, Wang M, Chiu C. Soil mineral-organic matter-microbe interactions: Impacts on biogeochemical processes and biodiversity in soils. Pedobiologia 2005; 49: 609-635.

Inouhe M. Phytochelatins. Brazilian Journal of Plant Physiology 2005; 17: 65-78.

Jastrow JD, Koeppe DE. Uptake and Effects of Cadmium in Higher Plants. In: Nriagu JO, editor. Cadmium in the Environment Part I: Ecological Cycling. New York: Wiley and Sons; 1980. p. 607-638.

Johansson EM, Fransson PMA, Finlay RD, van Hees PAW. Quantitative analysis of root and ectomycorrhizal exudates as a response to $\mathrm{Pb}, \mathrm{Cd}$ and As stress. Plant Soil 2008; 313: 3954.

Jones DL, Dennis PG, Owen AG, van Hees PAW. Organic acid behavior in soils misconceptions and knowledge gaps. Plant Soil 2003; 248: 31-41.

Khan G. Role of soil microbes in the rhizospheres of plants growing on trace metal contaminated soils in phytoremediation. Journal of Trace Elements in Medicine and Biology 2005; 18: 355-364.

Kirkham MB. Cadmium in plants on polluted soils: Effects of soil factors, hyperaccumulation, and amendments. Geoderma 2006; 137: 19-32.

Koopmans GF, Römkens PFAM, Fokkema MJ, Song J, Luo YM, Japenga J, Zhao FJ. Feasibility of phytoremediation to remediate cadmium and zinc contaminated soils. Environmental Pollution 2008; 156: 905-914.

Krpata D, Fitz W, Peintner U, Langer I., Schweiger P. Bioconcentration of zinc and cadmium in ectomycorrhizal fungi and associated aspen trees as affected by level of pollution. Environmental Pollution 2009; 157: 280-286.

Latham RE, Steckel DB, Harper HM, Steckel C, Boatright M. Lehigh Gap Wildlife Refuge Ecological Assessment - For the Lehigh Gap Nature Center, Slatington, Pennsylvania. Pennsylvania. Natural Lands Trust, Continental Conservation, Botanical Inventory: 2007.

Lebeau T, Braud A, Jézéquel K. Performance of bioaugmentation-assisted phytoextraction applied to metal contaminated soils: A review. Environmental Pollution 2008; 153 : 437-522.

Lee JL, Weber DE. The effects of acid rain on seedling emergence and growth of eleven woody species. Forest Science 1979; 25: 393-398.

Lorenz SE, Hamon RE, Holm PE, Domingues HC, Sequeira EM, Christensen TH, McGrath SP. Cadmium and zinc in plants and soil solutions from contaminated soils. Plant Soil 1997; 189: 21-31.

Marschner H. Mineral Nutrition in Higher Plants. $2^{\text {nd }}$ Edition, London, Academic Press; 2002. 
Massop KF, Davidson CM, Ure AM, Shand CA, Hillier SJ. Effect of EDTA on the fractionation and uptake by Taraxacum officinale of potential toxic elements in soil from former chemical manufacturing sites. Plant Soil 2009; 320: 117-129.

Matúš P. Evalutaion of separation and determination of phytoavailable and phytotoxic aluminium species fractions in soils, sediment and water samples by fiver different methods. Journal of Inorganic Biochemistry 2007; 101: 1214-1223.

McIntyre T. Phytoremediation of heavy metals from soils. In: Tsao DT, editor. Phytoremediation, Advances in Biochemical Engineering Biotechnology, Vol 78. New York: Springer-Verlag; 2003. p. 98-123.

McGrath SP, Zhao FJ, Lombi E. Plant and rhizosphere process involved in phytoremediation of metal-comtaminated soils. Plant Soil 2001; 232: 207-214.

Meharg AA. The mechanistic basis of interactions between mycorrhizal associations and toxic metal cations. Mycological Research 2003; 107: 1253-1265.

Mehlich A. Mehlich 3 soil extractant: A modification of the Mehlich 2 extractant. Communications on Soil Science and Plant Analysis 1984; 15: 1409-1416.

Ott T, Fritz E, Polle A, Schützendübel A. Characterisation of antioxidative systems in the ectomycorrhiza-building basidiomycetes Paxillus involutus (Bartsch) Fr. and its reaction to cadmium. Federation of European Microbiological Societies Microbiology Ecology 2002; 42: 359-366.

Pazzaglia FJ, Braun DD, Pavich M, Bierman P, Potter N, Merritts D, Walter R, Germanoski D. Rivers, glaciers, landscape evolution, and active tectonics of the central Appalachians, Pennsylvania and Maryland. In: Pazzaglia FJ, editor. Excursions in Geology and History: Field Trips in the Middle Atlantic States: Geological Society of America Field Guide 8. Denver: Geological Society of America; 2006. p. 169-197.

Prasad MNV. Cadmium toxicity and tolerance in vascular plants. Environmental and Experimental Botany 1995; 35: 525-545.

Qin R, Hirano Y, Brunner I. Exudation of organic acid anions from poplar roots after exposure to $\mathrm{Al}, \mathrm{Cu}$, and Zn. Tree Physiology 2007; 27: 313-320.

Rauret G, López-Sánchez JF, Sahuquillo A, Rubio R, Davidson C, Ure A, Quevaviller Ph. Improvement of the BCR three step sequential extraction procedure prior to the certification of new sediment and soil reference materials. Journal of Environmental Monitoring 1999; 1: 57-61.

Ryan, PR, Delhaize E, Jones DL. Function and mechanism of organic anion exudation from plant roots. Annu. Rev. Plant Physiol. Plant Mol. Biol. 2001; 52: 527-560.

Sanità di Toppi L, Gabbrielli R. Response to cadmium in higher plants. Environmental and Experimental Botany 1999; 41: 105-130.

Sell J, Kayser A, Schulin R, Brunner I. Contribution of ectomycorrhizal fungi to cadmium uptake of poplars and willows from a heavily polluted site. Plant Soil 2005; 277: 245253.

Tao S. Liu WX, Chen YJ, Cao J, Li BG, Xu FL. Fractionation and bioavailability of copper, cadmium and lead in rhizosphere soil. In: Huang PM, Gobran GR, editors. Biogeochemistry of Trace Elements in the Rhizosphere. New York: Elsevier; 2005. p. 313-336.

Thomas GW. Soil pH and soil acidity. In: Bigham JM, editor. Methods of Soil Analysis: Part 3 Chemical Methods, Soil Science Society of America Series No. 5. Madison: Soil Science Society of America and American Society of Agronomy; 1996. p. 475-490. 
UNEP. Annual Report - A Year in Review. Nairobi: United Nations Environment Programme; 2011.

USEPA. Palmerton Zinc Superfund Site Blue Mountain Project, Summary of RI/FS Results. Philadelphia: USEPA Region III; 1987. p. 1-85.

USEPA. Final Draft Palmerton Zinc Site Ecological Risk Assessment. Philadelphia: USEPA Region III; 2001.

USFWS. Preassessment screen for the Palmerton-Zinc Pile. Washington D.C.: United States Department of Interior; 2003.

Wenzel WW. Rhizosphere processes and management in plant-assisted bioremedation (phytoremediation) of soils. Plant Soil 2009; 321: 385-408.

Wenzel WW, Lombi E, Adriano DC. Biogeochemical Processes in the Rhizosphere: Role in Phytoremediation of Metal-Polluted Soils. In: Prasad M, Hagemeyer J, editors. In Heavy Metals Stress in Plants: From Biomolecules to Ecosystems. New York: Springer Verlag; 2004. p. 273-303.

Wu F, Yang W, Zhang J, Zhou L. Cadmium accumulation and growth responses of a poplar (Populus deltoids x Populus nigra) in cadmium contaminated purple soil and alluvial soil. Journal of Hazardous Materials 2010; 177: 268-273. 
Table 3.1 Soil Characteristics and Metal Availability for four soils collected from LGWR in Palmerton, Pennsylvania

\begin{tabular}{|c|c|c|c|c|c|c|c|c|c|c|c|}
\hline \multirow[b]{2}{*}{ Sample } & \multirow[b]{2}{*}{$\begin{array}{c}\text { Soil } \\
\mathrm{pH}_{\mathrm{H} 2 \mathrm{O}}\end{array}$} & \multirow[b]{2}{*}{$\begin{array}{l}\text { TOC } \\
(\%)\end{array}$} & \multirow[b]{2}{*}{$\begin{array}{c}\text { CEC } \\
\text { (meq/100 g) }\end{array}$} & \multirow[b]{2}{*}{$\underset{(\mathrm{mg} / \mathrm{kg})^{1}}{\mathrm{Cd}_{\text {Total }}}$} & \multirow{2}{*}{$\begin{array}{c}\mathrm{Zn}_{\text {Total }} \\
(\mathrm{mg} / \mathrm{kg})^{1}\end{array}$} & \multicolumn{2}{|c|}{$0.005 \mathrm{M} \mathrm{EDTA}^{2}$} & \multicolumn{2}{|c|}{$0.005 \mathrm{M} \mathrm{DPTA}^{2}$} & \multicolumn{2}{|c|}{ Mehlich-III $^{2}$} \\
\hline & & & & & & $\begin{array}{c}\mathrm{Cd} \\
(\mathrm{mg} / \mathrm{kg})\end{array}$ & $\begin{array}{c}\mathrm{Zn} \\
(\mathrm{mg} / \mathrm{kg})\end{array}$ & $\begin{array}{c}\mathrm{Cd} \\
(\mathrm{mg} / \mathrm{kg})\end{array}$ & $\begin{array}{c}\mathrm{Zn} \\
(\mathrm{mg} / \mathrm{kg})\end{array}$ & $\begin{array}{c}\mathrm{Cd} \\
(\mathrm{mg} / \mathrm{kg})\end{array}$ & $\begin{array}{c}\mathrm{Zn} \\
(\mathrm{mg} / \mathrm{kg})\end{array}$ \\
\hline $\begin{array}{c}\text { PLM-B1 } \\
\text { (Non- } \\
\text { Amended) }\end{array}$ & 5.42 & 18.3 & 28.6 & 254 & 13503 & 31 & 1835 & 26 & 1659 & 9 & 614 \\
\hline $\begin{array}{l}\text { PLM-B2 } \\
\text { (Non- } \\
\text { Amended) }\end{array}$ & 5.60 & 6.8 & 13.7 & 138 & 7909 & 23 & 982 & 17 & 1018 & 10 & 594 \\
\hline $\begin{array}{l}\text { PLM-B3 } \\
\text { (Non- } \\
\text { Amended) }\end{array}$ & 5.44 & 21.5 & 29.6 & 262 & 11170 & 28 & 1444 & 25 & 1771 & 9 & 854 \\
\hline $\begin{array}{l}\text { PLM-B4 } \\
\text { (Amended) }\end{array}$ & 6.36 & 2.8 & 8.7 & 40 & 4783 & 8 & 542 & 5 & 605 & 3 & 575 \\
\hline Typical $^{3}$ & - & - & - & $0.01-2$ & $1-900$ & - & - & - & - & - & - \\
\hline USEPA $^{4}$ & - & - & - & 1.2 & 150 & - & - & - & - & - & - \\
\hline $\mathrm{PA} \mathrm{DCNR}^{5}$ & - & - & - & $\begin{array}{l}293- \\
1750\end{array}$ & $\begin{array}{l}11800- \\
135000\end{array}$ & - & - & - & - & - & - \\
\hline
\end{tabular}

${ }^{1}$ Both Zn and Cd totals of field samples were determined by Geoscience Laboratories, Ontario, Canada. Non-Amended - collected outside "test-plots" from a non-amended location; Amended - collected within "Test-Plots" and have received a regime of amendments (In methods).

${ }^{2}$ EDTA and DPTA extraction methods from Matús and others (2005); Mehlich-III extraction method from Mehlich (1984). Results are from Figueroa (2015)

${ }^{3}$ Typical soil concentrations are from Trace Elements in Terrestrial Environments: Biogeochemistry, Bioavailability, and Risk of Metals $2^{\text {nd }}$ Edition, D. Adriano, Springer, New York, 2001.

${ }^{4 / 5}$ Both USEPA and PA DCNR soil concentrations are from Region III Ecological Guidelines and the Palmerton Zinc Superfund Site, Palmerton, PA, respectively. These values are found in Preassessment Screen Determination for the Palmerton Zinc Pile Superfund Site, Pennsylvania DCNR, Harrisburg, 2003 (USFWS, 2003). 
Table 3.2 Summary statistics for Populus hybrid growth response to $\mathrm{Cd}$, Zn-contaminated soils and modification by inoculation with P. involutus

\begin{tabular}{|c|c|c|c|c|c|c|c|c|c|c|c|}
\hline \multicolumn{2}{|c|}{ Treatment } & \multirow{2}{*}{ 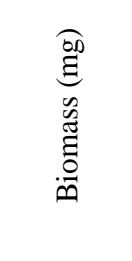 } & \multirow{2}{*}{ 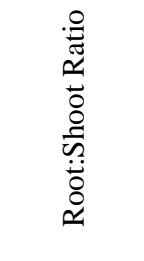 } & \multicolumn{4}{|c|}{ Cadmium Plant Information } & \multicolumn{4}{|c|}{ Zinc Plant Information } \\
\hline Soil & Myc & & & $\begin{array}{c}\mathrm{Cd}_{\text {Shoot }} \\
(\mathrm{mg} / \mathrm{kg}) \text { dry } \\
\text { weight }\end{array}$ & $\begin{array}{c}\mathrm{Cd}_{\text {Root }} \\
(\mathrm{mg} / \mathrm{kg}) \text { dry } \\
\text { weight }\end{array}$ & $\begin{array}{c}\mathrm{Cd}_{\text {Total }} \\
\text { Content } \\
\text { (mg/plant) }\end{array}$ & TF & $\begin{array}{c}\mathrm{Zn}_{\text {Shoot }} \\
(\mathrm{mg} / \mathrm{kg}) \\
\text { dry weight }\end{array}$ & $\begin{array}{c}\mathrm{Zn}_{\text {Root }} \\
(\mathrm{mg} / \mathrm{kg}) \\
\text { dry weight }\end{array}$ & $\begin{array}{c}\mathrm{Zn}_{\text {Total Content }} \\
\text { (mg/plant) }\end{array}$ & TF \\
\hline \multirow{2}{*}{$\begin{array}{c}\text { Non- } \\
\text { Amended }\end{array}$} & Non-Myc & $1100 \pm 689 b$ & $0.28 \pm 0.18 b$ & $24 \pm 2.69 \mathrm{a}$ & $85.9 \pm 9.97 \mathrm{a}$ & $0.025 \pm 0.016 \mathrm{ab}$ & $0.28 \pm 0.056 \mathrm{~b}$ & $724 \pm 170 \mathrm{bc}$ & $5065 \pm 670 \mathrm{a}$ & $0.76 \pm 0.51 b$ & $0.15 \pm 0.036 \mathrm{~b}$ \\
\hline & Myc & $1540 \pm 581 \mathrm{ab}$ & $0.35 \pm 0.27 \mathrm{ab}$ & $24.1 \pm 3.56 \mathrm{a}$ & $98.5 \pm 4.79 \mathrm{a}$ & $0.030 \pm 0.015 \mathrm{a}$ & $0.24 \pm 0.036 \mathrm{~b}$ & $600 \pm 81 \mathrm{c}$ & $5423 \pm 670 \mathrm{a}$ & $0.77 \pm 0.41 b$ & $0.11 \pm 0.025 b$ \\
\hline \multirow{2}{*}{ Amended } & Non-Myc & $1960 \pm 611 \mathrm{a}$ & $0.45 \pm 0.13 \mathrm{a}$ & $9.7 \pm 0.72 \mathrm{c}$ & $41.1 \pm 7.99 \mathrm{~b}$ & $0.014 \pm 0.0047 \mathrm{~b}$ & $0.24 \pm 0.030 \mathrm{~b}$ & $918 \pm 108 \mathrm{a}$ & $3606 \pm 500 \mathrm{~b}$ & $1.27 \pm 0.31 \mathrm{a}$ & $0.26 \pm 0.055 \mathrm{a}$ \\
\hline & Мyc & $2330 \pm 680 \mathrm{a}$ & $0.42 \pm 0.31 \mathrm{ab}$ & $16.6 \pm 2.39 \mathrm{~b}$ & $44 \pm 6.62 \mathrm{~b}$ & $0.028 \pm 0.0089 a$ & $0.38 \pm 0.065 \mathrm{a}$ & $842 \pm 172 \mathrm{ab}$ & $3396 \pm 160 b$ & $1.46 \pm 0.55 \mathrm{a}$ & $0.21 \pm 0.057 \mathrm{a}$ \\
\hline \multicolumn{12}{|c|}{ Treatment Effects } \\
\hline Soil & & $* *$ & $*$ & $* * *$ & $* * *$ & $* * *$ & - & $*$ & $* * *$ & $* * *$ & $* * *$ \\
\hline Myc & & $*$ & - & $*$ & $* * *$ & $*$ & $* *$ & $* *$ & $*$ & - & - \\
\hline Soil x Myc & & - & - & - & $* * *$ & - & - & $* * *$ & - & - & - \\
\hline
\end{tabular}

Non-Amended sample refers to PLM-B2 and Amended sample refers to PLM-B4

Biomass = Root Wt .+ Shoot Wt.; Translocation Factor $(\mathrm{TF})=[\mathrm{M}]_{\text {Shoot }} /[\mathrm{M}]_{\text {Root }} ;[\mathrm{M}]_{\text {Total Content }}\left(\mathrm{mg}_{\text {plant }}{ }^{-1}\right)=$ Avg. Shoot Wt. $^{*}[\mathrm{M}]_{\text {Shoot }}$

Statistical Significance: $*=p<0.05 ; * *=p<0.01 ; * * *=p<0.001$

Values $(n=4)$ are means \pm SD. 
Table 3.3 Pseudototal (aqua-regia soluble) of Cadmium and Zinc in LGWR soils following 8-week growth with Populus and/or P. involutus ( $\mathrm{mg} / \mathrm{kg})$

\begin{tabular}{|c|c|c|c|c|c|c|}
\hline Soil & Metal & Field Sample & $\mathrm{U}$ & Myc & Pop & Myc x Pop \\
\hline \multirow{2}{*}{ Non-Amended } & $\mathrm{Cd}$ & $147 \pm 5$ & $135 \pm 9.73 \mathrm{ab}$ & $151 \pm 7.60 \mathrm{a}$ & $124 \pm 18.1 b$ & $139 \pm 14.6 \mathrm{ab}$ \\
\hline & $\mathrm{Zn}$ & $7990 \pm 1360$ & $7920 \pm 281 a$ & $7690 \pm 624 a$ & $7040 \pm 548 a$ & $7760 \pm 800 a$ \\
\hline \multirow{2}{*}{ Amended } & $\mathrm{Cd}$ & $69 \pm 2$ & $65 \pm 2.91 \mathrm{a}$ & $58 \pm 2.88 \mathrm{a}$ & $40 \pm 12.9 b$ & $41 \pm 11.8 b$ \\
\hline & $\mathrm{Zn}$ & $4650 \pm 1205$ & $4790 \pm 146 a$ & $4550 \pm 474 a$ & $4440 \pm 305 a$ & $4750 \pm 240 a$ \\
\hline
\end{tabular}

Results presented are means \pm SD of replicate analysis $(n=4)$ besides "Field Sample" $(n=3)$. Means followed by the same letters within rows are not significantly different $(\mathrm{p}<0.05)$.

Non-Amended sample refers to PLM-B2 and Amended sample refers to PLM-B4

$U=$ untreated, $M y c=$ mycorrhizae present, $P o p=$ poplar present, $M y c \times$ Pop = Both mycorrhizae and poplar present 

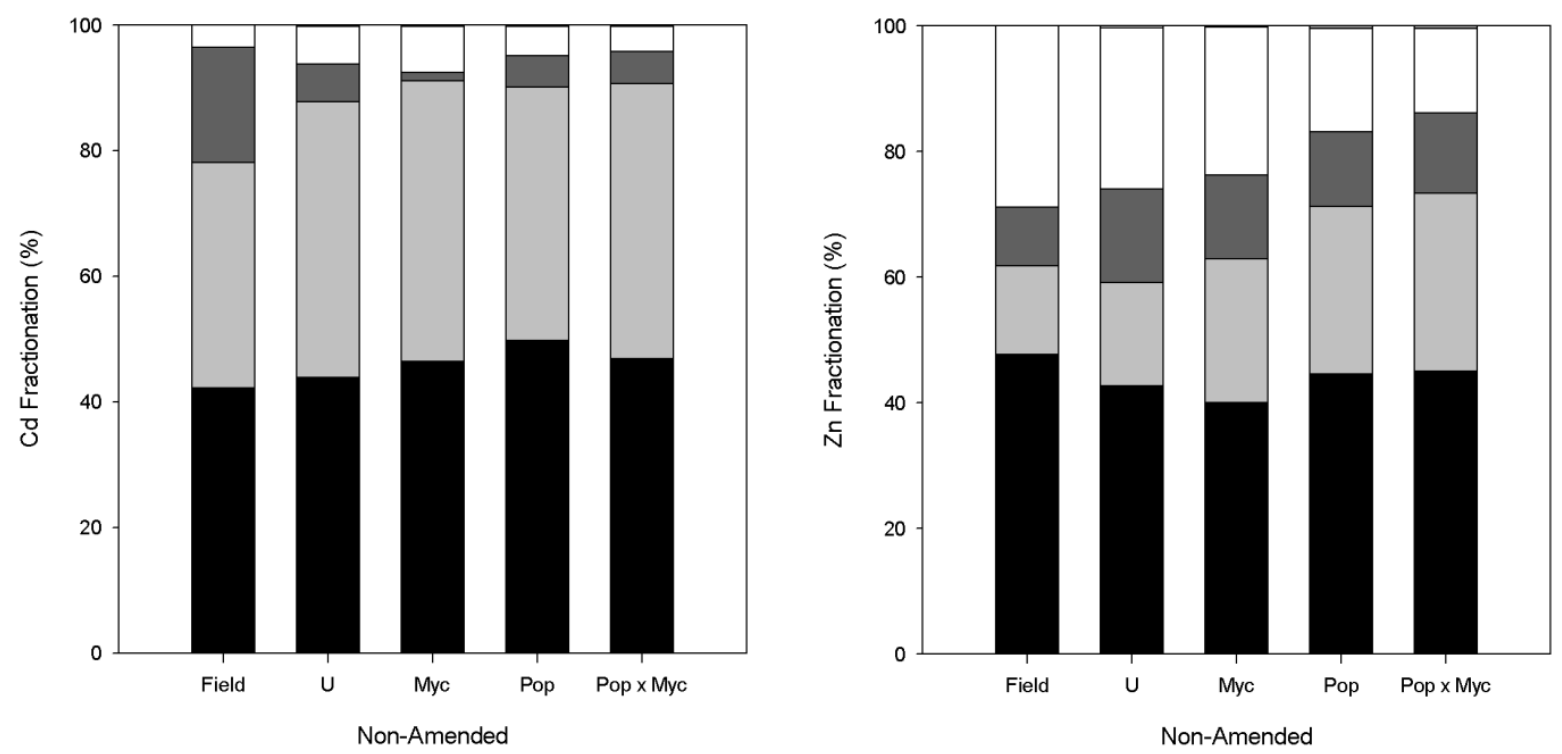

$\square$ Exchangeable $\square$ Reducible $\square$ Oxidizable $\square$ Residual $\square$ Leachate
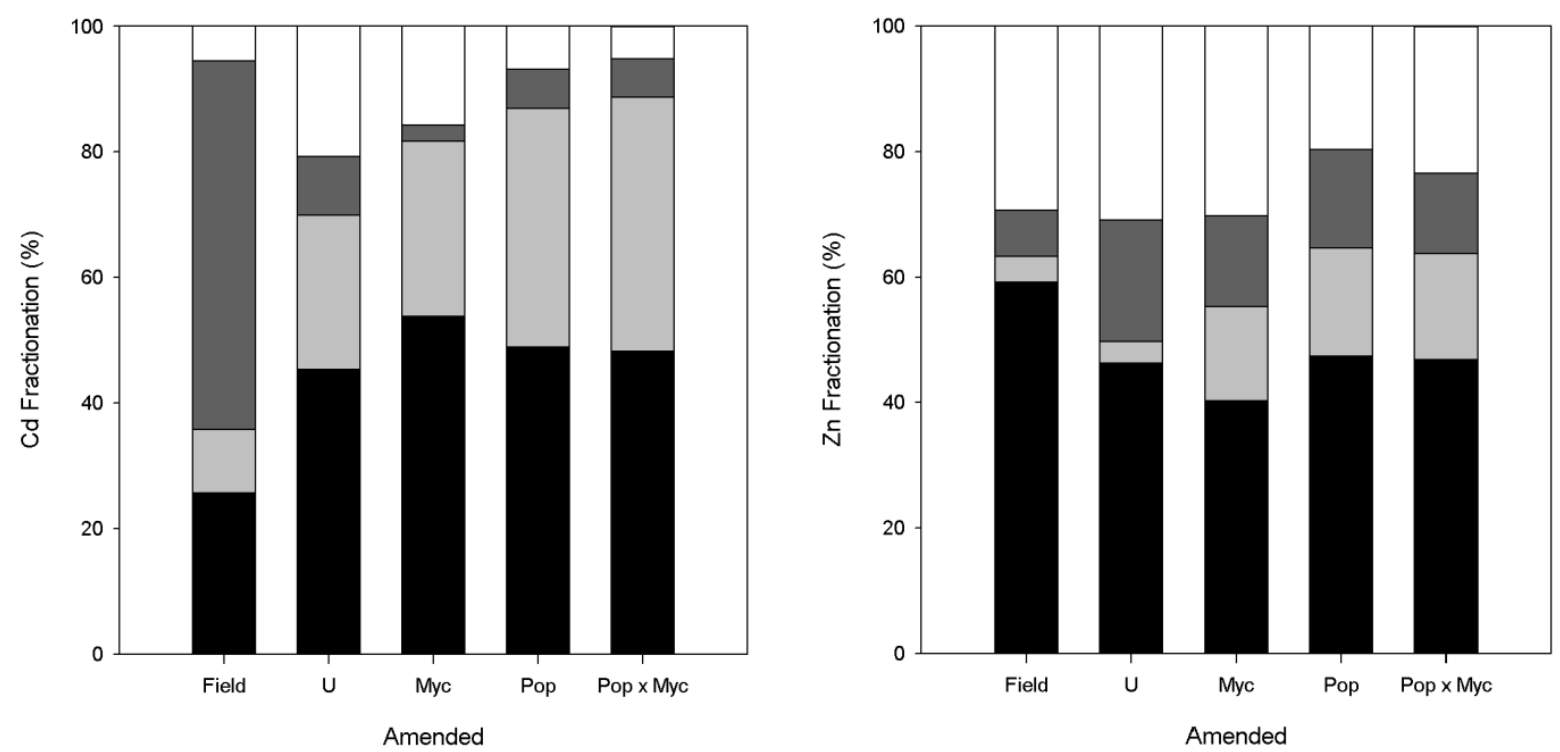

Figure 3.1 Revised BCR Sequential Extraction Fractionation Data for LGWR soils following 8weeks of growth with Populus and/or P. involutus. Non-amended refers to sample PLM-B2 and amended refers to sample PLM-B4. Field = original sample; $\mathrm{U}=$ untreated; Myc $=$ mycorrhizae added; Pop $=$ with poplar; Pop x Myc $=$ with poplar and mycorrhizae. Results presented are mean of replicate analysis $(n=4)$ besides "Field" Sample $(n=3)$. 

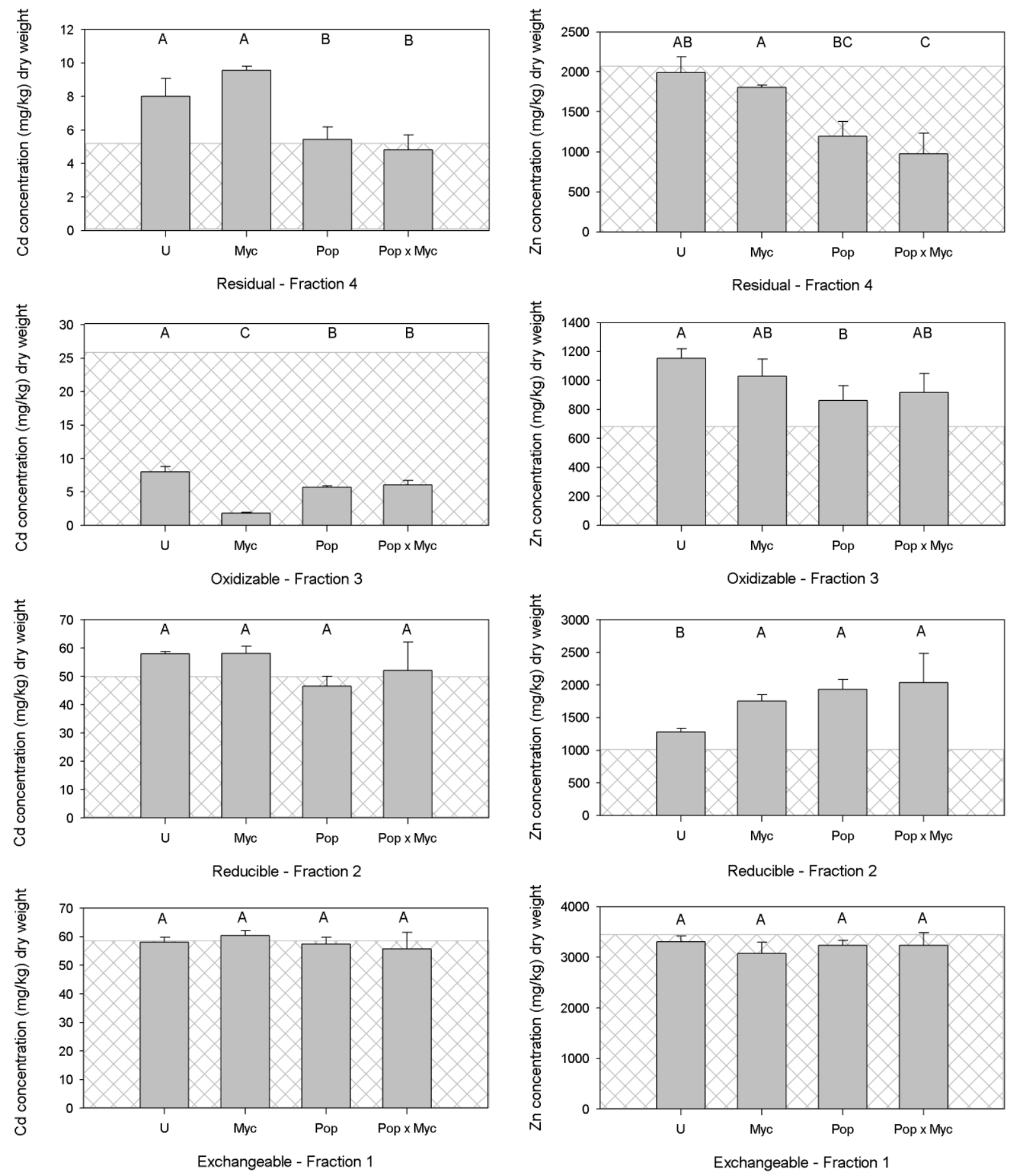

Figure 3.2 Non-amended sample data from the Revised BCR Sequential Extraction for LGWR soils following 8-weeks of growth with Populus and/or P. involutus. Original field soil concentration illustrated by cross-lines. Values $(n=4)$ are means \pm SD. Differing letters indicate significant differences among planting treatments by Tukey Kramer HSD $\alpha=0.05$. U = untreated; Myc $=$ mycorrhizae added; Pop $=$ with poplar; Pop $\mathrm{x}$ Myc $=$ with poplar and mycorrhizae. 

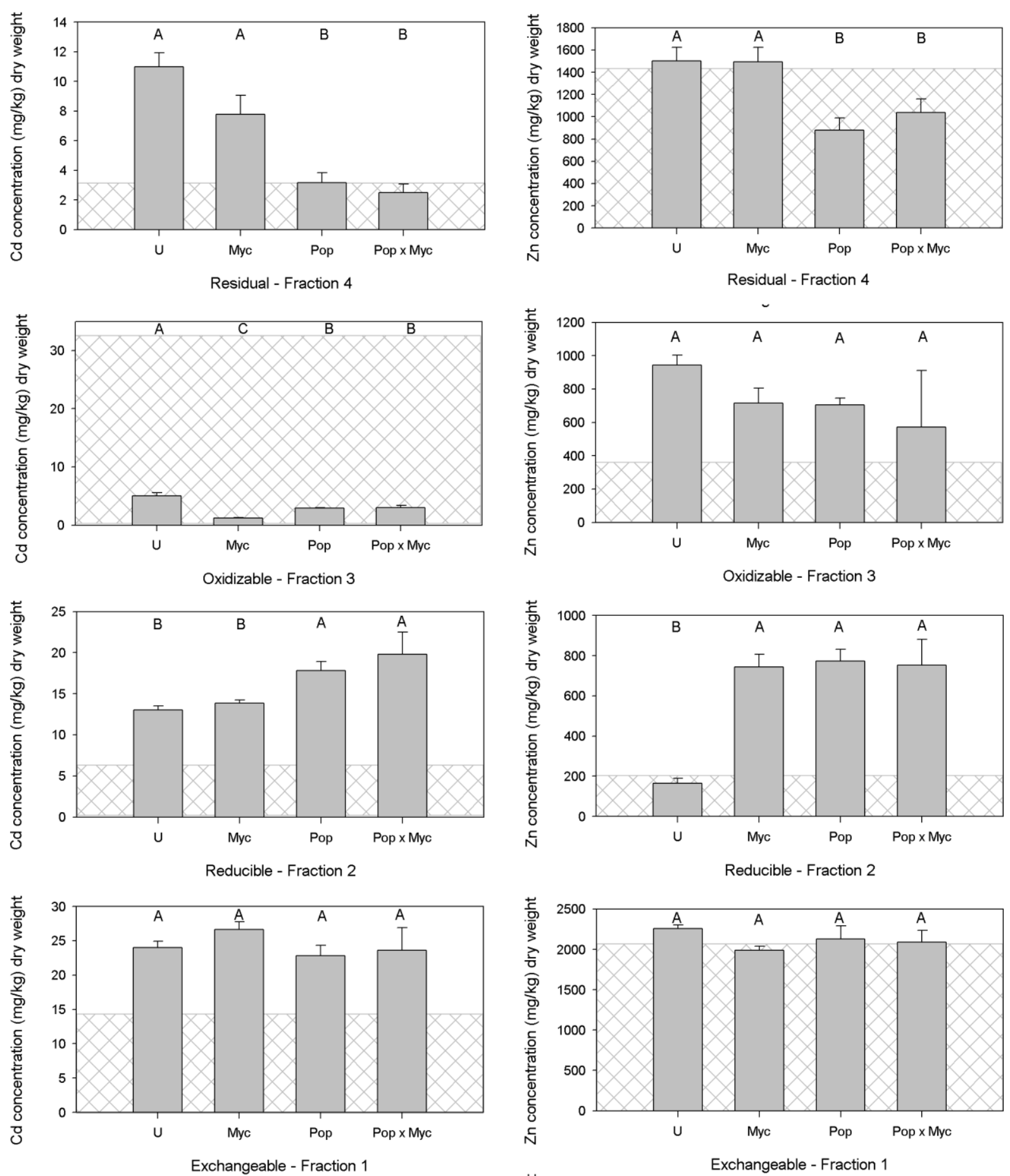

Figure 3.3 Amended sample data from the Revised BCR Sequential Extraction for LGWR soils following 8-weeks of growth with Populus and/or P. involutus. Original field soil concentration illustrated by cross-lines. Values $(n=4)$ are means \pm SD. Differing letters indicate significant differences among planting treatments by Tukey Kramer HSD $\alpha=0.05$. U = untreated; Myc $=$ mycorrhizae added; Pop = with poplar; Pop x Myc = with poplar and mycorrhizae. 

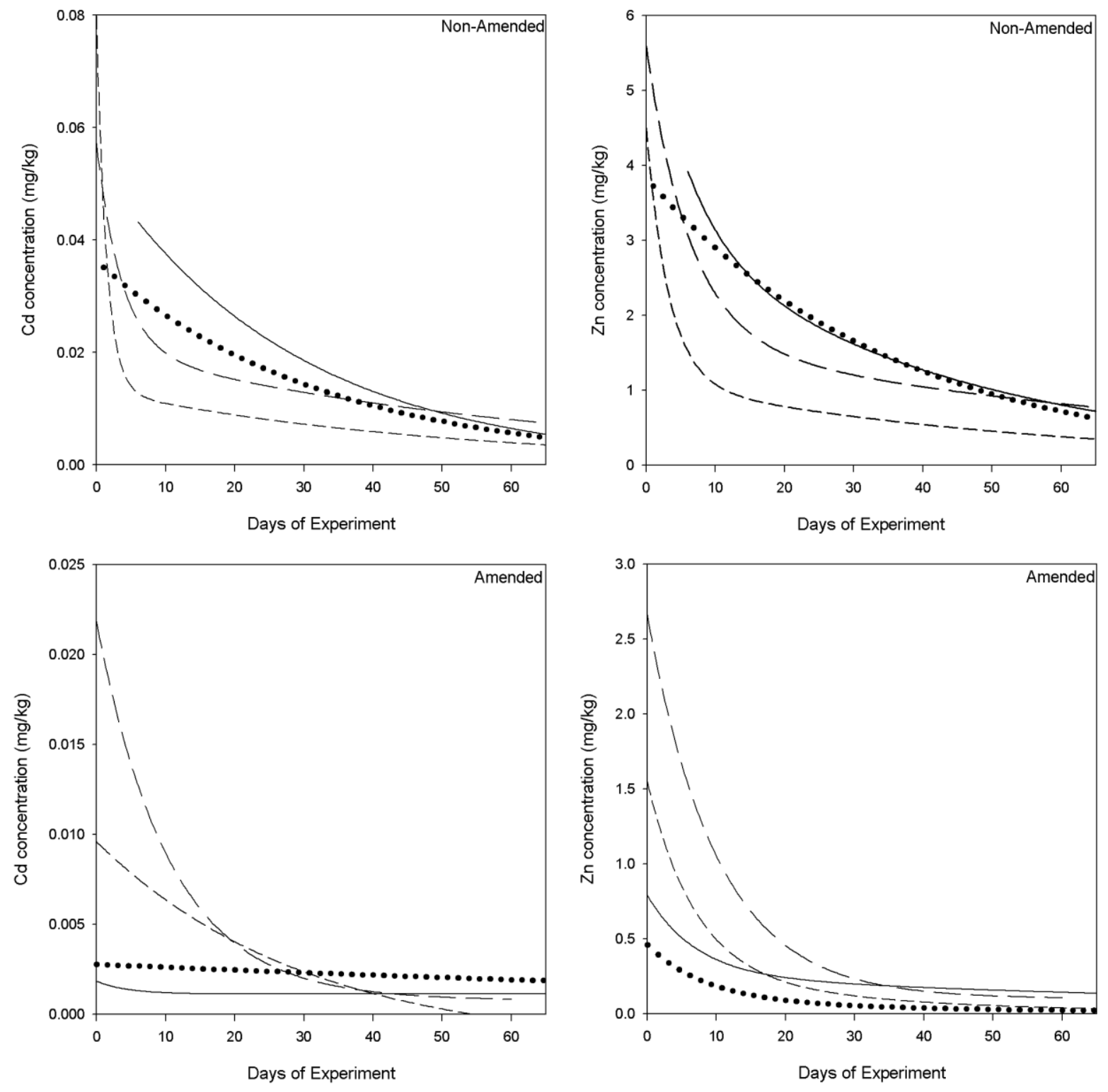

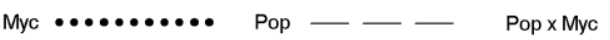

Figure 3.4 Leachate Depletion Curves for greenhouse experiment for LGWR soils following 8weeks of growth with Populus and/or P. involutus. $\mathrm{U}=$ untreated; Myc = mycorrhizae added; Pop $=$ with poplar; Pop $\mathrm{x}$ Myc $=$ with poplar and mycorrhizae. 


\section{CONCLUSIONS}

In this study we observed how contaminated soils from a derelict zinc-smelter site can be highly available when exposed to treatments, both biological and chemical. With the aid of commonly-used single-extractions (e.g., EDTA, DTPA, Mehlich-III) we were able to establish the availability of both $\mathrm{Cd}$ and $\mathrm{Zn}$ in four soil samples collected, based on traditional soil extraction techniques to determine plant availability. Along with these common extractions, we confirmed methods that mimic rhizosphere conditions (RBM) with fungal exudates produced along with liquid fungal cultures are useful in interpreting availability and these treatment effects significantly influence availability. The use of the revised BCR Sequential Extraction method elucidated conditions that are operationally defined by extractant, but gave insight to availability defined in the first-step to compare against these common extraction methods to determine availability in environmental samples. The short-term release of $\mathrm{Cd}$ and $\mathrm{Zn}$ was also determined to show the potential for environmental risk associated with inoculation of soils when used to aid remediation projects. Along with background work associated with metal availability studies, we observed the "before" and "after" effects on two soils collected that overall demonstrated that with introduction of biology (e.g., fungi and poplar) the chemical fractionation determined by sequential extraction changed significantly. Specifically, the Populus hybrid along with Paxillus involutus used in this study had great influence on soil chemistry, but also sequestered $\mathrm{Cd}$ with significant effects. This affirms that this system can be used to ameliorate contaminated sites affected by $\mathrm{Cd}$ exposure and with further research more varieties of hybrid poplars and mycorrhizal fungi can be tested to be effective on both metals studied along with many other heavy metals that pose a risk to the environment and human health. 
Table A.1 Significance of treatment effects for soils exposed to mycorrhizal, poplar, and mycorrhizal $x$ poplar treatments on non-amended and amended Palmerton (LGWR) soils in 8-week growth study

\begin{tabular}{|c|c|c|c|c|c|c|c|c|c|c|c|c|}
\hline \multirow[b]{2}{*}{ Non-Amended } & \multicolumn{4}{|c|}{ MYC } & \multicolumn{4}{|c|}{ Pop } & \multicolumn{4}{|c|}{ Pop*Myc } \\
\hline & $d f$ & 35 & $\mathrm{P}$ & & $d f$ & ss & $\mathrm{F}$ & & $d f$ & 38 & $\mathrm{P}$ & \\
\hline $\bar{F} 1 \_\mathrm{Zn}$ & 1 & 0.00500 & 1.36 & \begin{tabular}{|c|}
0.268 \\
\end{tabular} & 1 & 0.000740 & 0.202 & 0.662 & 1 & 0.00498 & 1.36 & 0.269 \\
\hline $\mathrm{F} 2 \mathrm{Zn}_{\mathrm{n}}$ & 1 & 0.112 & 6.24 & 0.0296 & 1 & 0.270 & 15.1 & 0.00250 & 1 & 0.0721 & 4.03 & 0.0700 \\
\hline F3_Zn & 1 & 0.00327 & 0.252 & 0.626 & 1 & 0.156 & 12.0 & 0.00530 & 1 & 0.0290 & 2.23 & 0.164 \\
\hline $\mathrm{F}^{4} \mathrm{Z}_{\mathrm{Z}}$ & 1 & 0.0190 & 0.579 & 0.463 & 1 & 0.912 & 28.7 & 0.000200 & 1 & 0.0850 & 2.68 & 0.130 \\
\hline SUM_Zn & 1 & 0.000318 & 0.0507 & 0.826 & 1 & 0.00947 & 1.51 & 0.245 & 1 & 0.00205 & 0.327 & 0.579 \\
\hline Psevdototal_Zn & 1 & 0.00593 & 0.945 & 0.202 & 1 & 0.00845 & 1.34 & 0.271 & 1 & 0.0116 & 1.84 & 0.202 \\
\hline $\mathrm{F} 1$ CCd & 1 & 0.0100 & 2.49 & 0.143 & 1 & $2.67 \mathrm{E}-06$ & 0.000700 & 0.980 & 1 & 0.0260 & 6.49 & 0.0271 \\
\hline $\mathrm{F} 2 \_\mathrm{Cd}$ & 1 & 0.0325 & 2.50 & 0.143 & 1 & 0.0622 & 4.77 & 0.0150 & 1 & 0.000204 & 0.0156 & 0.903 \\
\hline F3_Cd & 1 & 1.76 & 251 & $<0.0001$ & 1 & 0.710 & 101 & $<0.0001$ & 1 & 2.08 & 297 & $<0.0001$ \\
\hline F4_Cd & 1 & 0.0125 & 0.684 & 0.426 & 1 & 1.47 & 80.6 & $<0.0001$ & 1 & 0.0175 & 0.960 & 0.348 \\
\hline Sum_Cd & 1 & 0.00640 & 3.69 & 0.0809 & 1 & 0.0242 & 13.9 & 0.00330 & 1 & 0.000422 & 0.244 & 0.631 \\
\hline \multirow[t]{2}{*}{ Psevdototal_Cd } & 1 & 0.0645 & 6.43 & 0.0276 & 1 & 0.0182 & 1.81 & 0.206 & 1 & 0.000544 & 0.0542 & 0.820 \\
\hline & \multicolumn{4}{|c|}{ MYC } & \multicolumn{4}{|c|}{ Pop } & \multicolumn{4}{|c|}{ Pop*Myc } \\
\hline Amended & df & 35 & P & & $d f$ & 39 & $F$ & 5 & $d f$ & 38 & $\mathrm{~F}$ & \\
\hline F1_Zn & 1 & 0.0190 & 5.99 & \begin{tabular}{|c|}
0.0324 \\
\end{tabular} & 1 & 0.000181 & 0.0570 & 0.816 & 1 & 0.0110 & 3.45 & 0.0901 \\
\hline $\mathrm{F} 2 \mathrm{Zn}_{\mathrm{n}}$ & 1 & 2.03 & 126 & $<0.0001$ & 1 & 2.24 & 139 & $<0.0001$ & 1 & 2.22 & 138 & $<0.0001$ \\
\hline F3_Zn & 1 & 0.647 & 1.58 & 0.235 & 1 & 0.684 & 1.67 & 0.235 & 1 & 0.0708 & 0.173 & 0.685 \\
\hline $\mathrm{F} 4 \_\mathrm{Zn}$ & 1 & 0.0235 & 2.03 & 0.182 & 1 & 0.748 & 64.6 & $<0.0001$ & 1 & 0.0276 & 2.39 & 0.151 \\
\hline SUM_ $Z_{n}$ & 1 & 0.0000201 & 0.00420 & 0.949 & 1 & 0.0328 & 6.92 & 0.0234 & 1 & 0.000560 & 0.118 & 0.738 \\
\hline Psevdototal_Zn & 1 & 0.00000833 & 0.00150 & 0.970 & 1 & 0.00160 & 0.295 & 0.598 & 1 & 0.0162 & 2.98 & 0.112 \\
\hline $\mathrm{F} 1$ CCd & 1 & 0.0235 & 3.11 & 0.106 & 1 & 0.0217 & 2.87 & 0.118 & 1 & 0.00933 & 1.24 & 0.290 \\
\hline $\mathrm{F} 2$ _Cd & 1 & 0.0156 & 2.18 & 0.168 & 1 & 0.363 & 50.6 & $<0.0001$ & 1 & 0.00445 & 0.620 & 0.448 \\
\hline F3_Cd & 1 & 1.52 & 206 & $<0.0001$ & 1 & 0.177 & 23.9 & 0.0005 & 1 & 1.62 & 220 & $<0.0001$ \\
\hline $\mathrm{F} 4 \_\mathrm{Cd}$ & 1 & 0.300 & 8.43 & 0.0143 & 1 & 5.24 & 147 & $<0.0001$ & 1 & 0.00767 & 0.216 & 0.651 \\
\hline Sum_Cd & 1 & 0.0461 & 8.29 & 0.0150 & 1 & 0.108 & 19.4 & 0.00110 & 1 & 0.0884 & 15.9 & 0.00210 \\
\hline Psevdototal_Cd & 1 & 0.00721 & 0.144 & 0.711 & 1 & 0.796 & 15.9 & 0.00210 & 1 & 0.0138 & 0.276 & 0.610 \\
\hline
\end{tabular}


Table A.2 Significance of treatment effects on Populus hybrid exposed to amended soils and mycorrhizal fungi (P. involutus) in 8-week growth study

\begin{tabular}{|c|c|c|c|c|c|c|c|c|c|c|c|c|}
\hline \multirow[t]{2}{*}{ Measurement } & \multicolumn{4}{|c|}{ Amended } & \multicolumn{4}{|c|}{ Myc } & \multicolumn{4}{|c|}{ Amended*Myc } \\
\hline & $\mathrm{df}$ & ss & $\mathrm{F}$ & $\mathrm{P}$ & $\mathrm{df}$ & ss & $\mathrm{F}$ & $\mathrm{P}$ & $\mathrm{df}$ & ss & $\mathrm{F}$ & $\mathrm{P}$ \\
\hline Shoot Cd & 1 & 4.89 & 207 & $<0.0001$ & 1 & 0.884 & 37.5 & $<0.0001$ & 1 & 0.871 & 36.9 & $<0.0001$ \\
\hline $\operatorname{Root} \mathrm{Cd}$ & 1 & 7.14 & 349 & $<0.0001$ & 1 & 0.125 & 6.10 & 0.0175 & 1 & 0.0151 & 0.739 & 0.395 \\
\hline Shoot Zn & 1 & 1.00 & 24.7 & $<0.0001$ & 1 & 0.225 & 5.55 & 0.0230 & 1 & 0.0312 & 0.769 & 0.385 \\
\hline Root Zn & 1 & 1.96 & 121 & $<0.0001$ & 1 & 0.000213 & 0.0131 & 0.909 & 1 & 0.0493 & 3.04 & 0.0880 \\
\hline Root Weight & 1 & 6.95 & 54.9 & $<0.0001$ & 1 & 1.23 & 9.74 & 0.00320 & 1 & 0.595 & 4.69 & 0.0358 \\
\hline Shoot Weight & 1 & 2.05 & 8.17 & 0.0065 & 1 & 0.615 & 2.46 & 0.124 & 1 & 0.0270 & 0.108 & 0.744 \\
\hline Biomass & 1 & 2.95 & 18.3 & 0.0001 & 1 & 0.790 & 4.90 & 0.0321 & 1 & 0.0834 & 0.517 & 0.476 \\
\hline Root:Shoot Ratio & 1 & 1.46 & 6.84 & 0.0122 & 1 & 0.107 & 0.502 & 0.482 & 1 & 0.368 & 1.73 & 0.195 \\
\hline Translocation Factor $\mathrm{Cd}$ & 1 & 0.213 & 5.14 & 0.0284 & 1 & 0.345 & 8.30 & 0.00610 & 1 & 1.12 & 26.9 & $<0.0001$ \\
\hline Translocation Factor $\mathrm{Zn}$ & 1 & 5.76 & 92.1 & $<0.0001$ & 1 & 0.239 & 3.82 & 0.0570 & 1 & 0.159 & 2.54 & 0.118 \\
\hline Total Content $\mathrm{Cd}$ & 1 & 0.608 & 2.30 & 0.137 & 1 & 2.974 & 11.2 & 0.00170 & 1 & 0.592 & 2.23 & 0.142 \\
\hline Total Content Zn & 1 & 5.91 & 21.7 & $<0.0001$ & 1 & 0.0963 & 0.354 & 0.555 & 1 & 0.000149 & 0.000500 & 0.981 \\
\hline
\end{tabular}

